\title{
The Rise, Fall, and Resurrection of Iceland: A Postmortem Analysis of the 2008 Financial Crisis
}

\begin{abstract}
This paper documents how the Icelandic banking system grew from 100 percent of GDP in 1998 to 900 percent of GDP in 2008, when it failed during the global financial crisis. We base our analysis on data from the country's three largest banks that were made public when the Icelandic parliament lifted, among other things, bank secrecy laws in order to investigate the run-up to the financial crisis. We document how the banks were funded and where the money went, using a comprehensive analysis of their lending. The recovery from the crisis was based on policy decisions that, in hindsight, seem to have worked well. We analyze some of these policies-including emergency legislation, capital controls, alleviation of balance of payments risks, and preservation of financial stability. We also estimate the crisis's output costs, which were about average when compared with the 147 banking crises documented by Luc Laeven and Fabián Valencia (2012) and the 100 banking crises documented by Carmen Reinhart and Kenneth Rogoff (2014). Our computation
\end{abstract}

Conflict of Interest Disclosure: Sigríður Benediktsdóttir is a board member for the Icelandic bank Landsbankinn, a paid position. The authors did not receive financial support from any firm or person for this paper or from any firm or person with a financial or political interest in this paper. With the exception of the aforementioned, they are currently not officers, directors, or board members of any organization with an interest in this paper. No outside party had the right to review this paper before publication.

1. The letter $Đ$ is the capital letter eth (eð; lowercase $ð)$ in the Icelandic alphabet. It can be transliterated $d$, and is pronounced with a soft $t h$ sound, as in "feather."

2. The letter $\mathbf{P}$ is the capital letter thorn (born; lowercase p) in the Icelandic alphabet. It can be transliterated th, as in "thick." 
of the Icelandic government's direct costs reveals that its recently concluded negotiations with foreign creditors may even leave it with a net surplus as a consequence of the crisis. However, there is still uncertainty about the ultimate cost, and our benchmark estimate is that the cost was about 5 percent of GDP. We summarize several lessons from the episode.

$\mathrm{n}$ some respects, Iceland was ground zero for the global financial crisis of 2008. Its entire banking system failed within the span of a week, sparking mass protests and eventually forcing the government to resign. This Icelandic saga captured the world's imagination. It was a topic for books, movies, and television shows. ${ }^{3}$ Some suggested it was a key parable of the folly of bankers gone wild, while others hailed the Icelandic government's response as a case study for how to recover from a banking crisis.

At some level, this extensive attention heaped on a tiny country of 330,000 people in the middle of the Atlantic Ocean is a mystery. Why would a country with a population equivalent to a few blocks in New York City command such attention? One indicator may shed light on this. Table 1 compares the Icelandic banking failure with the largest corporate bankruptcies in U.S. history - and the combined failure of the Icelandic banks comes in at number three, a few places below the Lehman Brothers failure. The Icelandic banks, which were largely state-owned in 2000, in only about five years after their privatization managed to grow into international banking franchises. Thus, in 2008, on the eve of the banking crisis, the three largest Icelandic banks' combined assets were about nine times Iceland's GDP, or $\$ 155$ billion ( $€ 115$ billion). This was the largest banking sector relative to GDP of any country in the world. Contrast this with the second-largest banking sector at the time, Switzerland's, which had a balance sheet of about eight times its GDP that had been accumulated during three long centuries of banking experience and institution building rather than in a few years.

In the annals of economic history, the Icelandic banks' stupendous growth perhaps belongs with the Dutch tulip mania of the 1600s. Yet the effects of this growth were even more dramatic. Once the Icelandic banks went bust, not only did people in Iceland suffer losses, but so too did hundreds of thousands of claimholders around the world. These included thousands

3. A few examples of books on the Icelandic crisis include Why Iceland (Jónsson 2009), Bringing Down the Banking System (Johnsen 2014), and The Icelandic Financial Crisis (Jónsson and Sigurgeirsson 2016). Iceland was also mentioned, among others, in the 2010 Oscar-winning movie Inside Job, written and directed by Charles Ferguson. 
Table 1. Iceland's Banking Failure Compared with America's Largest Bankruptcies

\begin{tabular}{llc} 
Company & Date of failure & $\begin{array}{c}\text { Total assets } \\
\text { (billions of dollars) }\end{array}$ \\
\hline Lehman Brothers & September 2008 & 639 \\
Washington Mutual & September 2008 & 328 \\
Icelandic banks & October 2008 & 155 \\
World.com & July 2002 & 104 \\
General Motors & June 2009 & 91 \\
\hline
\end{tabular}

Source: BankruptcyData.com.

of depositors in Britain and the Netherlands who thought their money was protected by insurance, in line with the European Union's rules. This led to a complicated international dispute, which for a while looked as if it would evolve into a serious trade conflict.

This paper tells the Icelandic banking saga. In itself, it is a worthwhile narrative, given this banking system's unprecedented growth and failure, which has been well documented, in part due to exceptional access to data. After the 2008 global financial crisis, the Icelandic parliament (Alpingi) established the Special Investigation Commission (SIC), which was composed of a supreme court judge, a parliamentary ombudsman, and an economist-Sigríður Benediktsdóttir - to address the basic questions of "What just happened?" and "Were any public officials responsible for mistakes or negligence?" ${ }^{4}$ The investigation was unique, in that Alpingi lifted all laws on bank secrecy in the public interest. Therefore, the SIC had unparalleled access to information about all the banks' operations, including their loan books, tax information, reports, and loan committees' documents and minutes. Moreover, it had subpoena power over bankers and any other relevant parties, such as politicians, business partners, and regulators.

The result of this effort was made public in a 3,000-page report in 2010. In the first part of this paper, we use the data from the SIC report to explain the run-up to the crisis. We have chosen to aggregate some of the report's data to give a more consistent macroeconomic picture that does not depend on the particulars of each bank. Furthermore, given that the report was written in 2010, we now have seven additional years of the banks' financial statements, which enable us to assess recovery rates and put the bank failure in a broader ex post context. In particular, they give us a better ability to answer the key question of whether or not the banks were solvent at the

4. The SIC report-Hreinsson, Benediktsdóttir, and Gunnarsson (2010), hereafter "SIC"-is written in Icelandic, though some chapters have been translated into English. 
time of the crash — and, if solvent, were thus victims of a self-fulfilling bank run, in the spirit of the research by Douglas Diamond and Philip Dybvig (1983). One of our key conclusions is that the banks were insolvent in 2008, although we acknowledge that this finding is highly speculative, for reasons we outline.

The Icelandic saga, which is interesting in its own right, is worth revisiting for at least three reasons. First, the Icelandic example is often heralded as a case study for how to deal with a bank crisis—let the banks go bust! but on relatively dubious premises. This popular account is not accurate. The domestic portion of the banking system was bailed out; deposits were given priority ex post ahead of other unsecured claims. The foreign portion of the failed banking system was granted a debt moratorium, and resolution committees were appointed to preserve the value of assets (Hafliðason, Valgeirsson, and Marinósson 2009). The real story, on which we seek to shed light, is more interesting than the stylized fiction. We suspect that some aspects of the Icelandic government's actions were inevitable at the time, and could therefore have predictive power for actions by other democratic governments faced with similar problems in the future.

Second, Iceland provides an interesting case study of the cost of a financial crisis. In Iceland, this cost was clearly immense; GDP declined more than 10 percent in real terms from peak to trough in 2010, and disposable income declined about 20 percent during the same period. However, the recovery has been relatively strong. We present evidence that the loss of output was relatively modest in an international context, given the enormous scale of the Icelandic financial sector's failure relative to the country's GDP. We also present new evidence on the fiscal cost of the crisis. The International Monetary Fund estimated in 2012 that the gross fiscal cost was 44 percent of GDP, and net about 20 percent, as reported by Luc Laeven and Fabián Valencia (2012). We update their estimate in light of recent developments. Relative to previous estimates and the enormity of the crisis, our benchmark net cost of about 5 percent of GDP seems modest. We also illustrate scenarios, which do not appear to be implausible, where there was a net fiscal gain from the crisis of about 1 percent of GDP.

There are also several noteworthy features of the recovery, such as the aggressive restructuring of households' and firms' debts in the aftermath of the crisis, which may help explain the relatively rapid recovery-and are tied closely to the literature on debt deleveraging (Eggertsson and Krugman 2012), and to the importance of cleaning up a firm's balance sheet to avoid the problem of "zombie firms" (Cabellero, Hoshi, and Kashyap 2008). The implementation of capital controls that were only recently lifted, as well 
as the "stability contributions" from the old banks' estates that prevented a balance of payments crisis, both supported the recovery and had substantial positive bearing on the final fiscal cost of the crisis.

Third, we think that several broad lessons can be learned whose value extends beyond Iceland. These are mostly stories that have been told before, but perhaps the starkness of Iceland's saga makes it a good illustration, along with the access to more detailed data documenting the banks' rise and fall, its causes, and its consequences. To cite only a few examples: The saga connects well with Raghuram Rajan's (1994) theory of credit erosion and dangers of too-rapid expansion in loan books (Jiménez and Saurina 2006). It is also a vivid example of the moral hazard and risk seeking triggered by explicit and implicit safety nets (Kareken and Wallace 1978), along with highlighting the dangers of bank runs in the absence of a viable lender of last resort (Diamond and Dybvig 1983).

The saga also highlights the importance of a robust supervisory authority and of having strong rules against large exposures and insider lending, connecting quite closely to the analyses of George Akerlof and Paul Romer (1993) and Simon Johnson and others (2000). Similarly, the banks' financing in foreign bond markets is an interesting example of what Markus Brunnermeier (2009) calls "regulatory and ratings arbitrage." Finally, the story of the large capital inflows leading to increased external leverage and systematic risk is an example of the mechanisms highlighted by Guillermo Calvo (1998), Paul Krugman (1999), Carmen Reinhart and Vincent Reinhart (2008), and Julián Caballero (2016). Many other connections to mechanisms identified in the literature could be highlighted further, and we attempt to provide several in what follows.

The Icelandic banks' accession into international franchises should also be interpreted in the context of a set of political ideas that became dominant in Western democracies toward the end of the last century. Their rise should be understood in the context of the Icelandic government's central focus not only on privatization and deregulation of all banks and thrifts, but also its goal to make Iceland an international financial center (Benediktsdóttir, Danílsson, and Zoega 2011). The government wanted the banks to expand, and the general attitude toward financial regulation in Iceland was that the best people to regulate the banks were the bankers themselves.

It is important to note, however, that this attitude was not a fringe view that was unique to Iceland; rather, it was part of a broader intellectual consensus among Western democracies. In his memoir, Ben Bernanke (2016, p. 70), former chairman of the Federal Reserve, a keen student of the Great Depression, and an intimate expert on banking problems, describes 
one of the key differences in views he had with Alan Greenspan, who was his predecessor as chairman of the Federal Reserve: "He did not put much stock in the ability of bank regulation and supervision to keep banks out of trouble. He believed that, so long as the banks had enough of their own money at stake, in the form of capital, market forces would deter them from unnecessarily risky lending."

At the most basic level, this paper should be read as a careful documentation of what happens when banks are left virtually unregulated and unchallenged, in a country that at the very least was perceived as having very strong democratic institutions and very low levels of corruption. ${ }^{5}$ The banks' capital, even if overstated, was above international regulatory requirements at the time of failure. As it turns out, market forces coupled with the banks' reported capital did not provide enough discipline. Meanwhile, in the United States, Greenspan came to realize that his previous views about bankers' ability to self-regulate did not hold up, stating in a congressional hearing on October 23, 2008, "Those of us who have looked to the self-interest of lending institutions to protect shareholders' equity, myself included, are in a state of shocked disbelief." The Icelandic saga is a good example from the 2008 financial crisis of the inability of bankers to regulate themselves. The lessons from the Icelandic saga seem all the more relevant now as a cautionary tale, as it appears the policy pendulum in Washington is swinging back to the precrisis consensus, toward tearing down the regulatory framework enacted following the 2008 financial crisis.

We document in detail the aggressive risk-seeking, insider lending, moral hazard, and virtually nonexistent bank supervision in Iceland leading up to the crisis. We find that about 20 percent of the banks' $€ 85$ billion loan book at the time of the failure went to only six groups of related parties, through a complex cobweb of holding companies that was largely unknown to supervisors at the time; for example, the lending of one bank to two of its principal owners was about $€ 1.5$ billion at the time of the failure, and these

5. We include the caveat "perceived" as opposed to claiming that Iceland "was" uncorrupt, because while Iceland ranked in international surveys at the time as the least corrupt country in the world, it is possible that those indicators of corruption were not picking up the right things. That it is impossible to bribe an Icelandic policeman, for example, may not be a good indicator of how hard or easy it is to avoid regulations or buy state-owned properties at subpar prices. Nepotism and cronyism are examples of corruption that is difficult to measure but may have been present. It is worth noting, however, that despite intense investigative effort into financially incentivized corruption - which included publicly releasing all bank loans to politicians and journalists - no evidence of bribery emerged and no corruption charges were issued by the special prosecutor, with the possible exception of a high-ranking employee of the Ministry of Finance who sold stocks in one of the banks after a meeting that revealed their fragile state. He was charged for insider trading and sentenced to jail by the Supreme Court. 
same owners had only invested about $€ 35$ million in equity to buy the bank five years earlier, when it was privatized (SIC, chap. 6).

The extent to which lessons from the Icelandic saga are generalizable boil down to one key point: The extent of the problems was only known ex post; after Alpingi, appointed a special investigative committee of economists, lawyers, and forensic accountants, and let them study the matter for more than a year; after Alpingi lifted bank secrecy laws and gave the investigative committee broad subpoena powers over all the main players. Furthermore, Alpingi appointed a special prosecutor to investigate the failed banks, which resulted in several charges, including against chief executives of all three of the major banks, all of whom were either sentenced to serve jail time or still have cases pending. Following the 2008 financial crisisor any other crisis for that matter-very few countries have put this amount of resources into investigating what went wrong. It is therefore very difficult to know the degree to which the Icelandic case is representative of international banking in general. Throughout this paper, we try to draw parallels to the extent possible to other known cases, such as the crises in Ireland, Italy, Mexico, and Southeast Asia, and the savings and loan crisis in the United States. But perhaps most important, we attempt to relate our findings to the economic literature developed before and after the crisis. Despite Iceland's particulars, we believe there are important lessons to be learned from our tale, which at various points may appear to be a tall one. The main lesson, which was echoed by Greenspan in his 2008 congressional hearing, is that the best people to monitor banks are not in fact the bankers themselves.

The paper proceeds as follows. In section I, we make general observations about the growth of the Icelandic financial sector. In section II, we document where and how the Icelandic banks funded their growth. This includes a discussion of the collection of Internet deposits in Britain and the Netherlands, which amounted to $€ 10$ billion at their peak, corresponding at that time to about 10 percent of the banks' balance sheets. We also discuss how the banks managed to borrow over $€ 6$ billion in collateralized funding from the European Central Bank and the Central Bank of Iceland. This involved, in part, one Icelandic bank printing a bank bond, in exchange for a bank bond issued by another Icelandic bank, and each posting that as collateral. Via this arrangement, the banks were essentially allowed to borrow money without limit and without meaningful collateral.

In section III, we discuss who received the funds. In particular, we take advantage of the unprecedented access of the SIC to loan books, derivative contracts, other lending contracts, all domestic tax returns, and other data sources. All the evidence suggests that the quality of the loan books eroded 
in the run-up to the crisis, that large exposures grew, and that the banks' owners - that is, the banks' insiders-borrowed disproportionally. Large exposures and insider borrowing posed a serious systemic risk largely unbeknownst to supervisors or other policymakers at the time. The data pinpoint the exact groups of individuals and firms that received the loans and the development of the exposure over time. We also document the form of these loans, which were more often than not loans with a single payment at the end of the loan period (that is, bullet loans), with no collateral or lax restrictions on collateral.

Section IV documents that a large share of the equity of the banks was "weak," in the sense that bank shares were funded directly by the banks themselves, with the shares themselves as the only collateral for the loans. This equity evaporated during the crisis, lowering recovery rates from the estates. In section V, we document the nature of the government's emergency laws when the banks faced a severe run on foreign currency funding, including deposits abroad. We suspect that these laws have predictive power for policy actions in time of stress in countries with a large international banking exposure, with important implications for cross-country regulations.

In section VI, we assess the recovery rate of the banks. On the basis of our estimates, we argue that it is difficult to maintain that the Icelandic banking system was solvent in 2008 and thus was not a victim of a classic self-fulfilling run. In section VII, we estimate the output cost of the banking crisis in Iceland and assess the sources of the recovery. In section VIII, we estimate the fiscal costs. In section IX, we discuss Iceland's postcrisis balance of payments problem and its experience with capital controls. In section X, we draw general implications and lessons. Section XI concludes.

\section{The Growth of Iceland's Three Largest Banks}

The three largest banks in Iceland, which accounted for over 95 percent of the country's banking system, expanded from about 100 percent of GDP in 1998 to 900 percent of GDP at the time of their failure in 2008 (see figure 1). ${ }^{6}$ This growth was often cited as evidence of the unsustainability of the Icelandic banking model. ${ }^{7}$

6. The measure used is the combined balance sheet of the three largest Icelandic banks: Kaupping, Glitnir, and Landsbanki.

7. The question of when a banking system is "too big" is an interesting and challenging one. Fitch Ratings (2006), for instance, focused on Iceland's net external debt and lack of experience with floating exchange rates as a "stress test"- as opposed to Australia or New Zealand. Other concerned observers included Merrill Lynch (Thomas 2006) and Danske Bank (Christiansen 2006). 
Figure 1. Liabilities of Glitnir, Kaupping, and Landsbanki as a Percentage of GDP, 2004-08

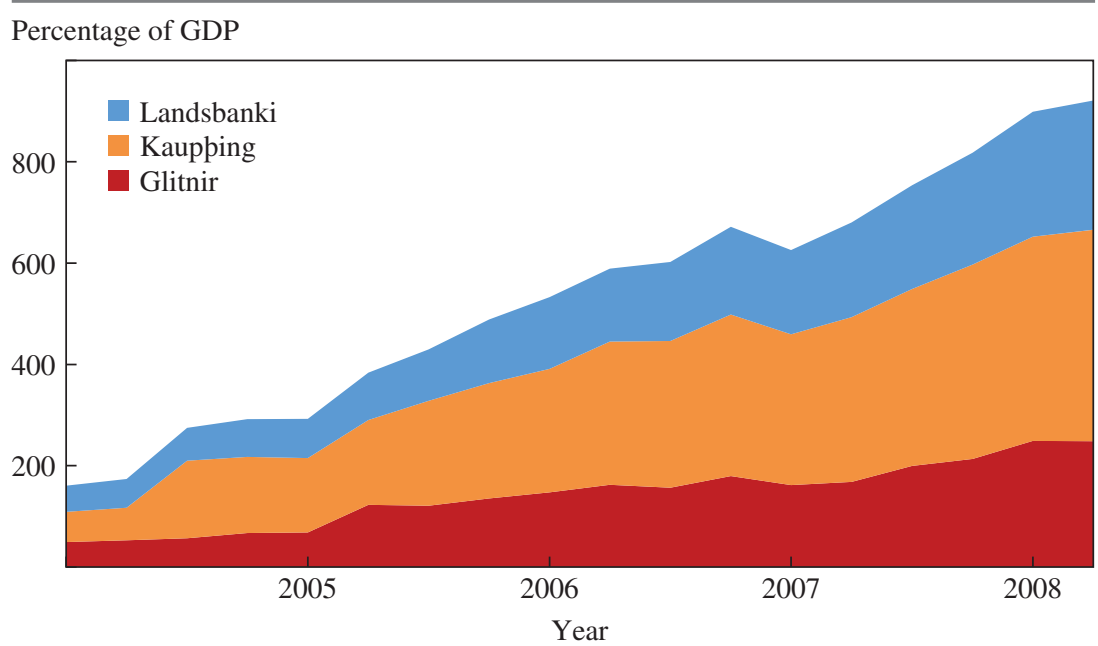

Source: SIC.

To put things in perspective, figure 2 shows the banking system's size as a percentage of Iceland's GDP in the run-up to the crisis and in comparison with selected industrialized economies with large banking sectors in 2007. The median-size banking system in this comparison is about three times GDP, which is about the 2004 level in Iceland. The three largest banks grew rapidly from 1998 to 2003 (figure 3), but their main growth spurt happened in the five years after that (figure 4), after the privatization of two of the three banks. But how did this all start, and who bought these banks?

Two groups of Icelandic investors bid for the banks in a controversial sale, whose details we will not go into here. How the purchases were financed, however, is quite relevant for the present purposes, as it seems to have set the tone for what was to come. At the risk of oversimplifying, each group borrowed money from other large banks in Iceland to fund its bank purchase, and some of the supposed foreign coinvestors turned out to be fronts for unknown Icelandic investors at the time. ${ }^{8}$

8. More precisely, Kaupping funded 70 percent of the purchase price of Landsbanki, while Landsbanki funded 35 percent of the purchase price of Bunadarbanki, which was acquired by Kaupping less than six months later. Moreover, as it turned out, a foreign coinvestor in Bunadarbanki later turned out to be a risk-free front for Icelandic coinvestors. 
Figure 2. National Banking Systems as a Percentage of GDP

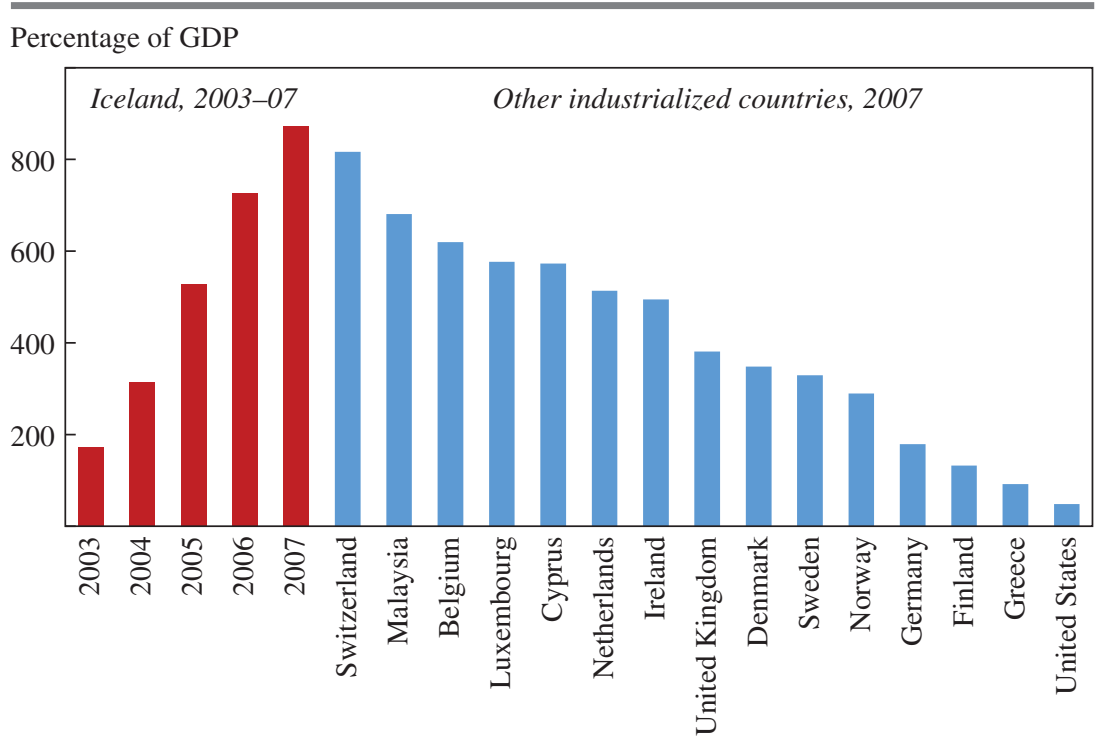

Source: CBI (2016a).

Figure 3. Combined Liabilities of Glitnir, Kaupping, and Landsbanki, 1998-2003

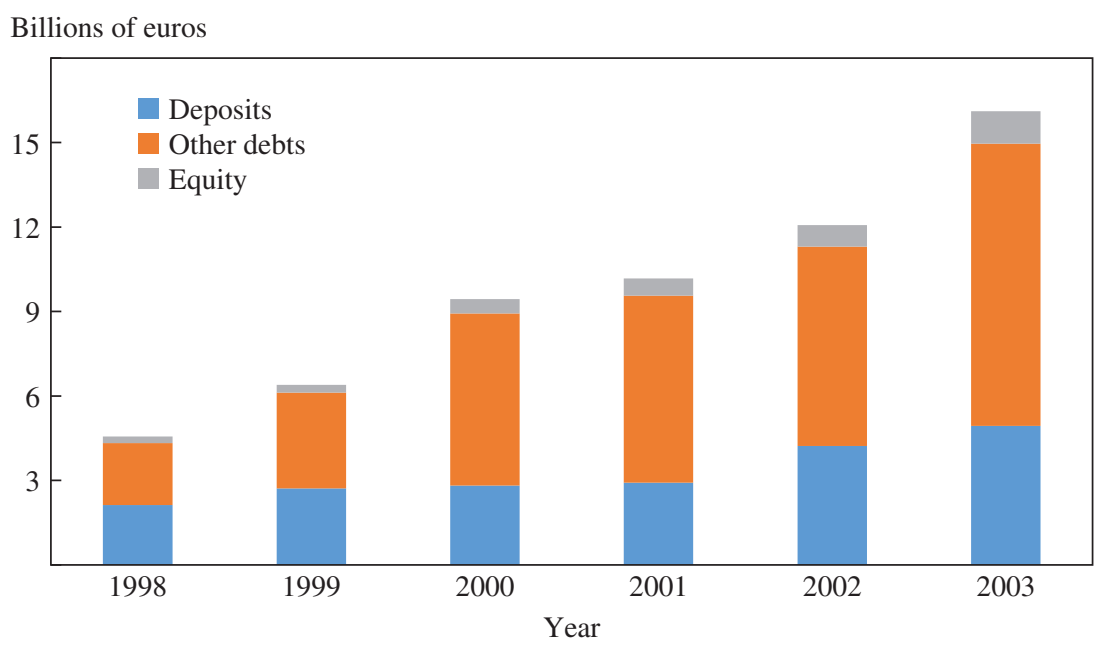

Source: SIC. 
Figure 4. Combined Liabilities of Glitnir, Kaupping, and Landsbanki, 1998-2008

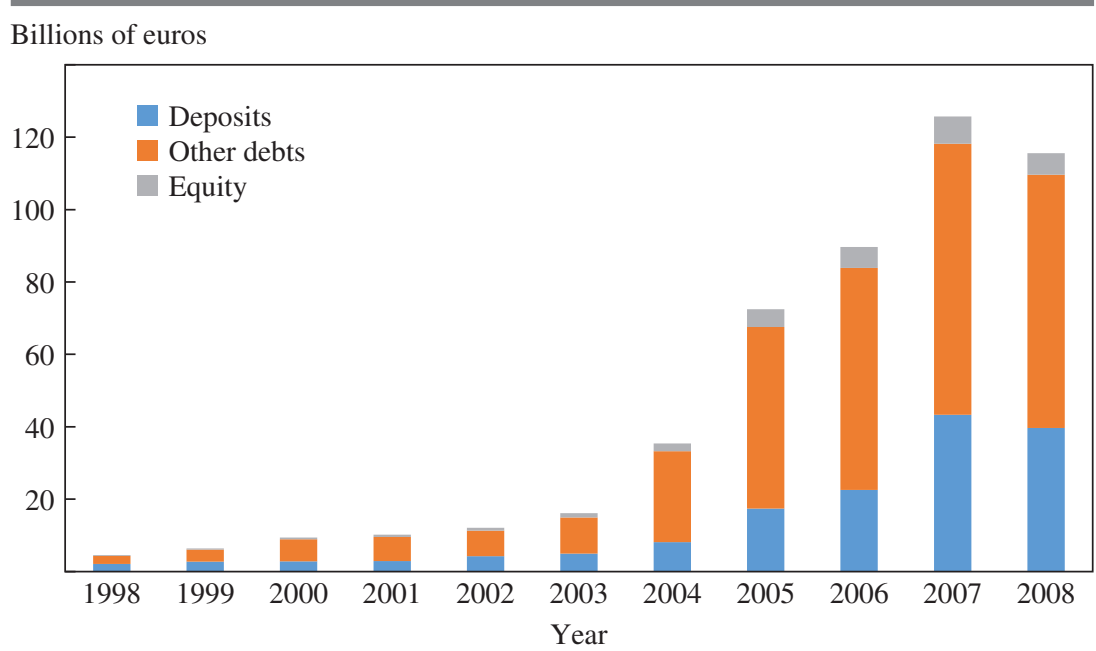

Source: SIC.

The facts about the origin of the banks' sales point to an important pattern. First, the banks' new owners were very closely connected, and they lent each other large amounts of money right from the start. Second, this kind of equity funding seriously weakened, in a nontransparent way, the banks' ability to suffer losses, and hence notably increased their systemic risk-as we further clarify in section IV. Third, from the beginning, the banks' ownership was murky, and supervisors and policymakers seemed complacent. This was the backdrop against which the banks started to expand.

Standard double-entry accounting techniques lead the way in how we answer the question, How could the Icelandic banks grow so much? First, we analyze the liability side-who was ready to lend the banks so much money? Second, moving to the asset side, where did it all go?

As shown in table 2, the largest part of the Icelandic banks' assets were loans to "customers." It is interesting to dig into who those customers were and the nature of the loans. We present evidence suggesting that the lending was disproportionally to large related parties and large owners of the banks.

It turned out that the Icelandic banks' equity was to a large extent selffunded-and hence was fictional. This is the major theme of section IV. Other important funding sources for the banks were deposits and borrowing, 
Table 2. Combined Balance Sheet of Glitnir, Kaupping, and Landsbanki, as of June 30, 2008

\begin{tabular}{lclc}
\hline Assets & Billions of euros & Liabilities & Billions of euros \\
\hline Cash and equivalents & 2 & Deposits & 45 \\
Loans to banks & 9 & Borrowings & 50 \\
Loans to customers & 74 & Other liabilities & 8 \\
Other assets & 30 & Subordinated debt & 5 \\
& & Equity & 7 \\
Total & \multirow{2}{*}{115} & Total & 115 \\
\hline
\end{tabular}

Sources: Balance sheets of Glitnir, Kaupping, and Landsbanki for 2008:Q2.

roughly in equal proportion. Where the funding originated is of considerable interest, and we go into detail on the available evidence in the next section.

\section{Where Did the Money Come From?}

This section addresses a basic question: How, exactly, did the Icelandic banking system increase its funding sevenfold in only five years?

Before the turn of the century, the Icelandic banks largely financed themselves via domestic deposits and long-term loans from foreign financial institutions. This changed, however, once the European financial market became more integrated. Although Iceland is not a member of the European Union, it is a member of the European Economic Area, giving it essentially the same access to financial markets as EU member countries. This included allowing the Icelandic banks to open subsidiaries and branches in EU member countries, which allowed the banks to collect deposits in Europe and do collateralized borrowing from the European Central Bank (ECB). Both would turn out to be quite important funding sources after the international liquidity crisis started in the middle of 2007.

The privatization of a large portion of the Icelandic banking system and its subsequent explosive growth did not occur in a vacuum. At the time, there was abundant global liquidity—what Bernanke (2005) termed at the time "the global saving glut"-and the premium on security investments in peripheral economies declined to record lows, as investors "searched for yield" (Bracke and Fidora 2008). The Icelandic banks benefited greatly from this situation, going from being a fringe investment to a highly rated mainstream investment opportunity. Capital inflows to Iceland through the banks grew greatly, elevating them to a prime example of what Reinhart and Reinhart (2008) term a "capital flow bonanza," which they show is highly 
Figure 5. Changes in Composition of Liabilities for Glitnir, Kaupping, and Landsbanki, 2004-08

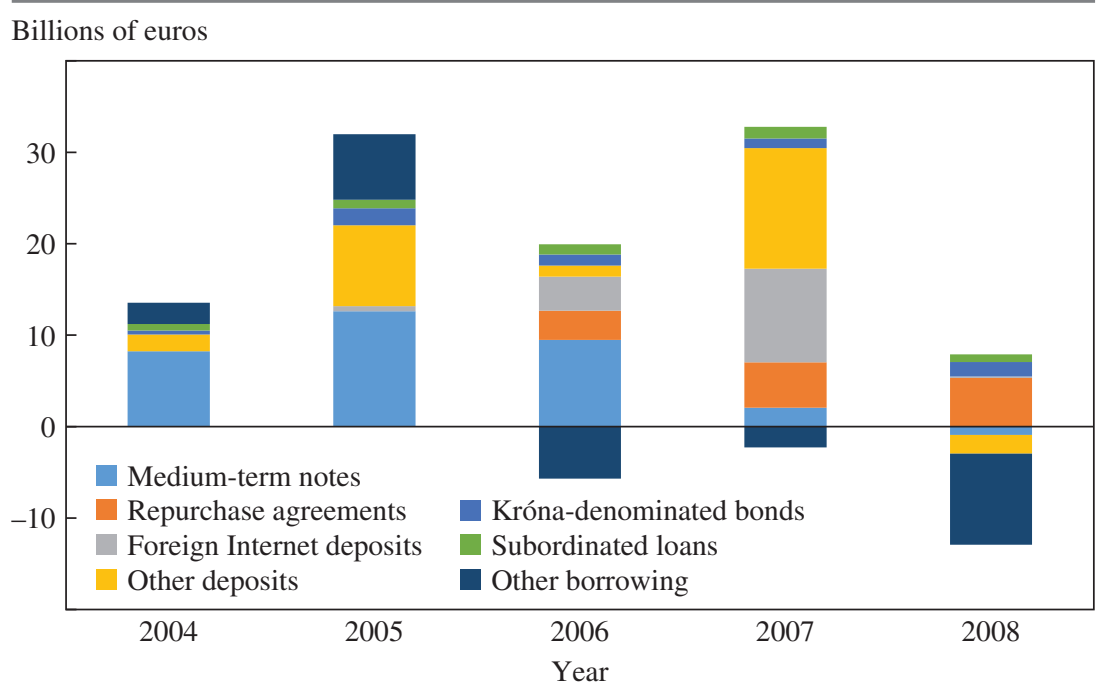

Sources: SIC; authors' calculations.

correlated with currency and banking crises. ${ }^{9}$ Meanwhile, the Icelandic economy was also set up for a boom independent of the banking expansion. In 2003, a four-year investment project began on a hydroelectric dam and aluminum smelter that amounted to about 50 percent of the tiny country's GDP (SIC, chap. 4).

We focus in the next paragraphs on the period of most rapid growth, which was after the banks were all in private hands - that is, after 2003. The banks' combined liabilities increased from a little under $€ 16$ billion to $€ 108$ billion. Roughly, we can divide this period into four stages, with the Icelandic banks entering new funding markets, as the conditions in their previous markets tightened.

Figure 5 shows how the composition of liabilities for the three banks changed from 2004 to 2008. During the first stage, in 2004 and 2005, the main source of funding growth came from the European medium-term note market. During the second stage, in 2006, an important source of funding was the U.S. bond market. And during the third stage, in 2006 and 2007, 
the banks started collecting Internet deposits in Europe. Finally, in 2007, and with increased vigor in 2008, the banks increased their collateralized borrowing, in particular from the ECB and the Central Bank of Iceland (Seðlabanki Íslands, or CBI). In its own way, each stage highlights possible problems that the economic literature has identified with the operation of modern financial markets.

\section{II.A. Stages 1 and 2: The European and U.S. Bond Markets}

Many banks moved to an "originate and distribute" model in the lead-up to the financial crisis, abandoning the model of retaining loans on their balance sheets. Banks repackaged the loans and sold them to various other financial investors, thereby offloading the risk via the "structured" products often referred to as collateralized debt obligations (CDOs). Brunnermeier (2009) gives a careful account of this process in the years preceding the crisis in the United States, which led to a weakening of credit standards and, ultimately, the crisis. A key problem with these products, according to this account, was that a substantial part of the risk was borne not by the originator but by other financial institutions that were eager to purchase these products in the environment of the "search for yields" before the crisis. This generated a classic principal-agent problem. The banks that bundled the assets into CDOs essentially only faced the "pipeline risks" of holding the assets for some period until the risks were passed on. Their incentives to evaluate the creditworthiness of borrowers were thus not sufficiently strong. Brunnermeier (2009) argues that this process was a key driver of cheap credit, declining lending standards, and the housing boom in the years preceding the severe financial crisis in the United States.

This development in financial markets helps explain the strong appetite for the Icelandic bank bonds in this period. From 2004 to 2008, the banks issued bonds, starting in the European bond market and then moving on to the U.S. bond market, that were valued at about $€ 45$ billion (see figure 6), or about 40 percent of the banks' balance sheets at the time of the financial crisis and three times Iceland's 2007 GDP.

Table 3 shows that Moody's credit ratings of the Icelandic banks in the 10 years before the financial crisis were very good. Investors had a strong appetite for Icelandic bank bonds because they were "cheap" in their rating class - that is, they had high returns relative to assets with comparable ratings. This gave rise to what Brunnermeier (2009) terms "regulatory and ratings arbitrage." The Icelandic bank bonds were a good way of increasing the credit rating of the CDOs with which they were bundled without compromising the returns (SIC, chap. 7). In early 2006, the spreads on the 
Figure 6. International Bond Issuance by Glitnir, Kaupping, and Landsbanki, 2004-08

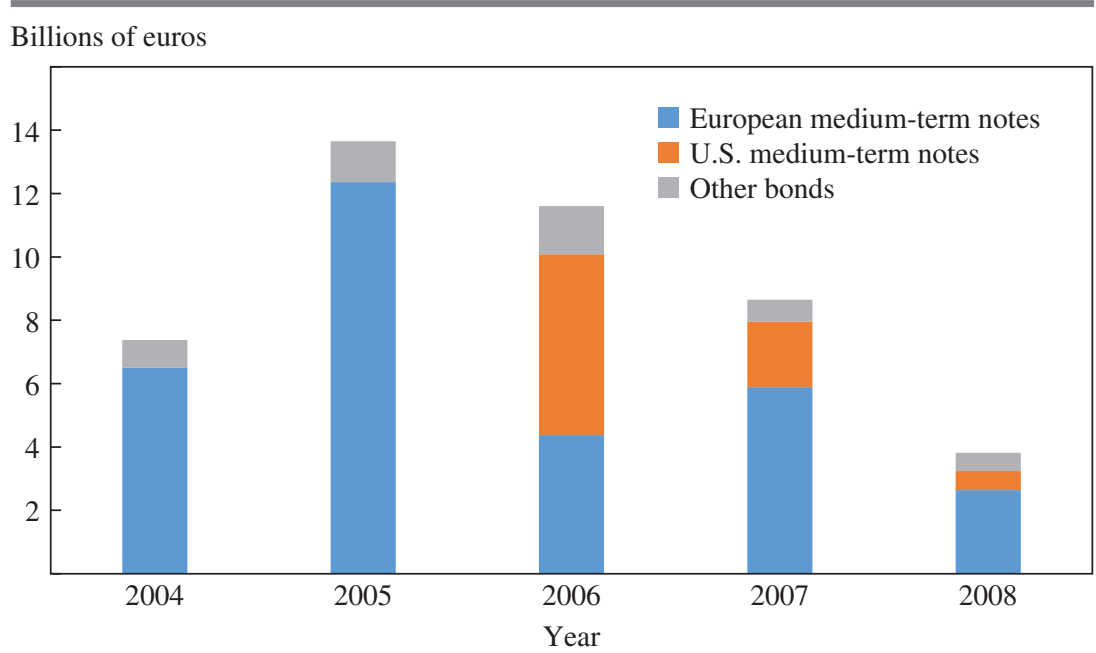

Source: SIC.

Table 3. Moody's Credit Ratings for the Long-Term Debt of Glitnir, Kaupping, and Landsbanki, 1998-2008

\begin{tabular}{llcc}
\hline Date & Glitnir & Landsbanki & Kaupping \\
\hline 1998 & A3 & A3 & \\
1999 & A3 & A3 & A3 \\
2000 & A2 & A3 & A3 \\
2001 & A2 & A3 & A3 \\
2002 & A2 & A3 & A3 \\
2003 & A1 & A3 & A2 \\
2004 & A1 & A2 & A1 \\
2005 & A1 & A2 & A1 \\
April 4, 2006 & A1 & A2 & A1 \\
February 23, 2007 & Aaa & Aaa & Aaa \\
April 11, 2007 & Aa3 & Aaa & Aaa \\
February 28, 2008 & A2 & A2 & A1 \\
September 30, 2008 & Baa2 & & \\
October 8, 2008 & Caa1 & Caa1 & \\
October 9, 2008 & & & Baa3
\end{tabular}

Source: SIC.

a. Kaupping merged with Bunadarbanki in 2003. 
Figure 7. Credit Default Swap Spreads for Glitnir, Kaupping, and Landsbanki, May 2006-October 2008

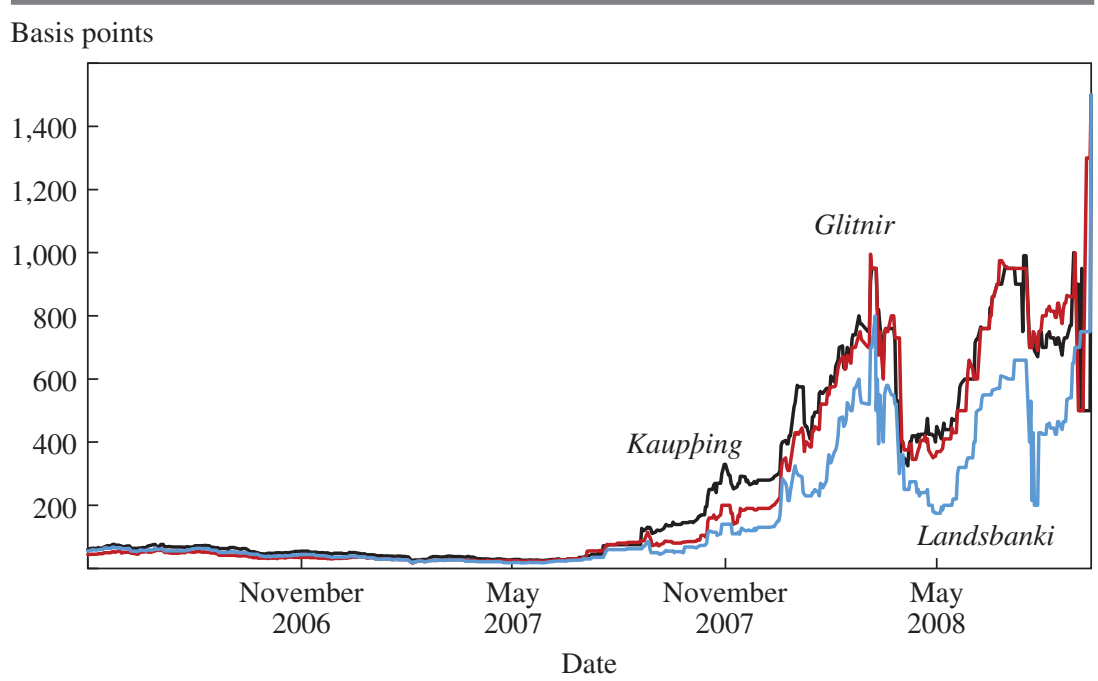

Source: SIC.

banks' bonds temporarily increased, in what was later termed the "geyser crisis," and access to the European bond market became limited. Later that same year, the U.S. bond market opened up, and the spreads lowered again and remained low until the liquidity crisis hit the international financial markets in midsummer 2007. ${ }^{10}$ At that stage, the spreads the banks had to pay in the bond market became prohibitively high, and the cost of insuring the banks' bonds peaked (figure 7). Accordingly, the banks started looking for alternative sources of funding.

\section{II.B. Stage 3: Deposit Collections}

EU law mandates a minimum deposit insurance of $€ 20,000$ per account, and many EU member countries increased this minimum during the crisis.

10. Given the close connection between European and U.S. markets, it may seem a bit surprising that the U.S. market "opened" to the Icelandic banks when the market in Europe "closed" to them. One possible explanation is that in the European case, most large investors became increasingly concerned about the health of the Icelandic banks, while the Icelandic banks could access the U.S. bond market via the regulatory and ratings arbitrage in CDOs in the United States, as we document above, where they were pooled with several other assets. 
Figure 8. Total Foreign Deposits of Glitnir, Kaupping, and Landsbanki, October 2007-September 2008

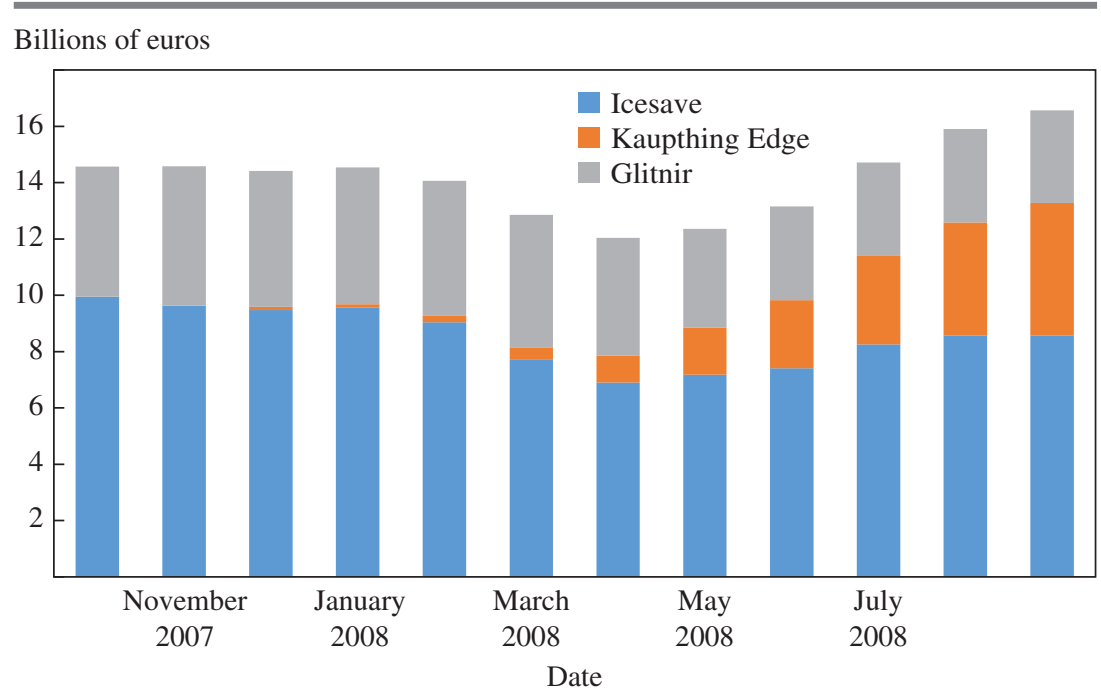

Source: SIC.

The classic problem created by deposit insurance is moral hazard-as illustrated, for example, by John Kareken and Neil Wallace (1978). It reduces the incentive for depositors to monitor banks, and hence incentivizes banks to take on higher risk than is socially optimal. The Icelandic banking saga provides a vivid example of bad incentives created by deposit insurance. The Icelandic banks repeatedly offered the highest deposit rates, according to weekly comparisons of deposit rates; and their advertisements and websites mentioned that the deposits fell under the EU-mandated deposit insurance (SIC, chap. 17, p. 262). For the Icelandic banks, obtaining deposits at relatively high interest expenses became preferred to the alternative, which was the increasingly tight bond market.

Starting in early 2006, after the so-called geyser crisis, the Icelandic banks began to collect deposits abroad. Landsbanki and Kaupping were particularly aggressive in Britain and the Netherlands. Foreign deposits increased to over $€ 16$ billion by the middle of 2008 (figure 8), corresponding to 15 percent of the banks' combined balance sheets at the time of failure. The great popularity of these accounts may appear somewhat puzzling, because at least as early as February 2006, ratings firms and 
other market observers had warned of the growth of the Icelandic banking system and its reliance on foreign funding, pointing out that the banks would most likely not be able to withstand losing access to the international financial markets. ${ }^{11}$ This was reflected in increases in credit default swaps, as shown in figure 7 .

High interest rates attracted investors to the deposit accounts. If a bank offered one of the three best deposit rates according to a list published weekly in the United Kingdom, there was a steady inflow into its accounts; but if a bank fell off the list, there was an outflow. ${ }^{12}$ Accordingly, these deposit accounts seem to have been very price sensitive. There is also some evidence that the deposit guarantee of $€ 20,000$ played a role. This can be gauged by the large number of accounts that were just below the $€ 20,000$ limit (SIC, chap. 17, p. 37).

Foreign deposit collections by the three largest Icelandic banks peaked at about $€ 14$ billion in fall 2007. Deposits then started to flow out-in particular, Landsbanki's so-called Icesave wholesale deposits, which were uninsured-until the spring of 2008, when Kaupping started collecting so-called Kaupthing Edge deposits, reinvigorating foreign deposit collections by the Icelandic banks, which then peaked at $€ 16$ billion shortly before the banks' failure (figures 8 and 9).

The behavior of the Icelandic banks in the European deposit market is reminiscent of the behavior of thrifts in 1980, which led to the savings and loan crisis, as documented by Akerlof and Romer (1993). A change in regulation meant that the savings and loan associations, which had governmentinsured deposits, could now set deposit rates at will. Akerlof and Romer (1993, p. 24) interpret this as having given the thrifts "an unlimited ability to borrow from the government" simply by making their government-insured deposits more attractive via higher rates.

\section{II.C. Stage 4: Central Bank Lending}

As the collection of deposits slowed in the fall of 2007, the banks turned to yet another funding source: the Central Bank of Iceland-and also, increasingly, the European Central Bank. Both banks' main policy tool is

11. Fitch Ratings revised Iceland's outlook to negative on widening macroeconomic imbalances on February 21, 2006 (Fitch Ratings 2006). Merrill Lynch revised its credit rating on March 7, 2006 (Thomas 2006), followed by Danske Bank on March 21, 2006 (Christiansen 2006).

12. A simple regression in the SIC report (chap. 7) shows that the inflows into the accounts were heavily dependent on where the banks were in the lists of highest deposit rates, which was published weekly. 
Figure 9. Icesave Deposits, November 2005-September 2008

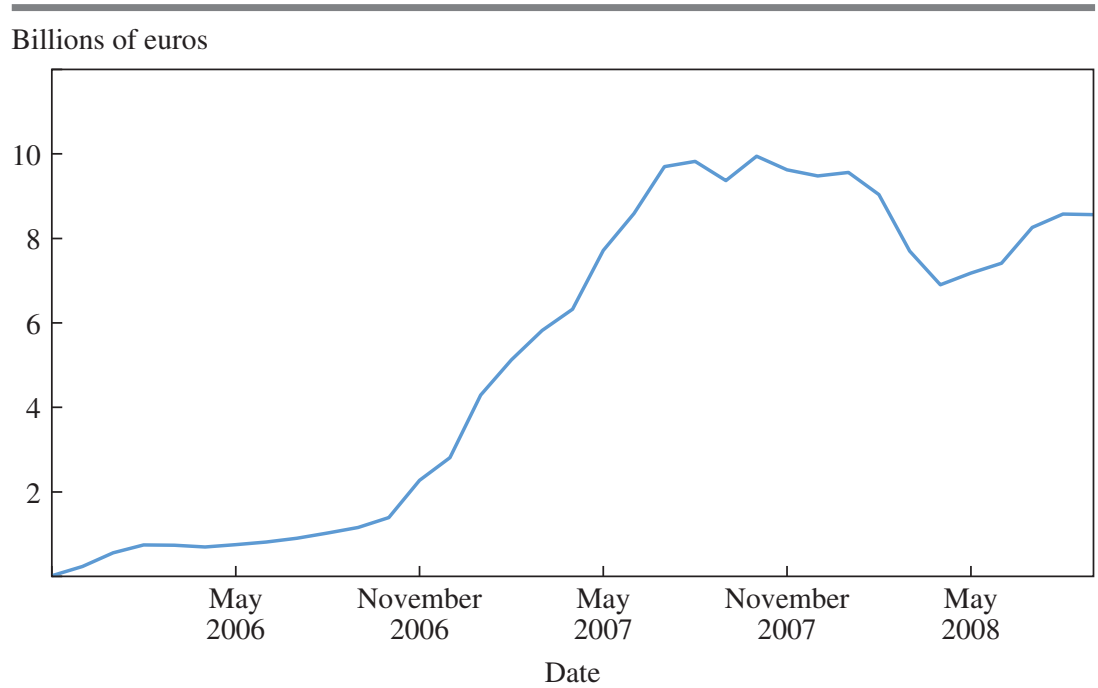

Source: SIC.

repurchasing agreements with banks, also known as collateralized lending to banks. The banks post collaterals at the central bank-with a haircutin exchange for liquidity, and then repay the loans after one week. The CBI and ECB use collateralized lending to control interbank lending rates, much in the same way the Federal Reserve in the United States uses open market operations to set the federal funds rate.

As liquidity started to tighten in mid-2007, the three largest Icelandic banks increased their collateralized borrowing from the CBI and ECB from about $€ 2$ billion to $€ 9$ billion (figure 10). The banks borrowed about $€ 3$ billion, directly or indirectly, from the CBI. The banks' collateralized borrowing from the ECB, through their subsidiaries in Luxembourg, was about $€ 1$ billion at the beginning of 2008 , and peaked at $€ 4.5$ billion in July 2008 (figure 11). The borrowing had come down to $€ 3.5$ billion when the banks failed. How the Icelandic banks funded themselves via collateralized borrowing from the CBI and ECB carries an important lesson for central banking that we suspect may be underappreciated.

Conducting monetary policy via collateralized lending and deposits is a simple way for the central bank to determine interbank rates. A key requirement for operations is that the underlying asset in the transaction is a highquality bond, to which a haircut may apply in order to minimize the central bank's credit risk. 
Figure 10. Collateralized Borrowing by Glitnir, Kaupping, and Landsbanki, June 2006-September 2008

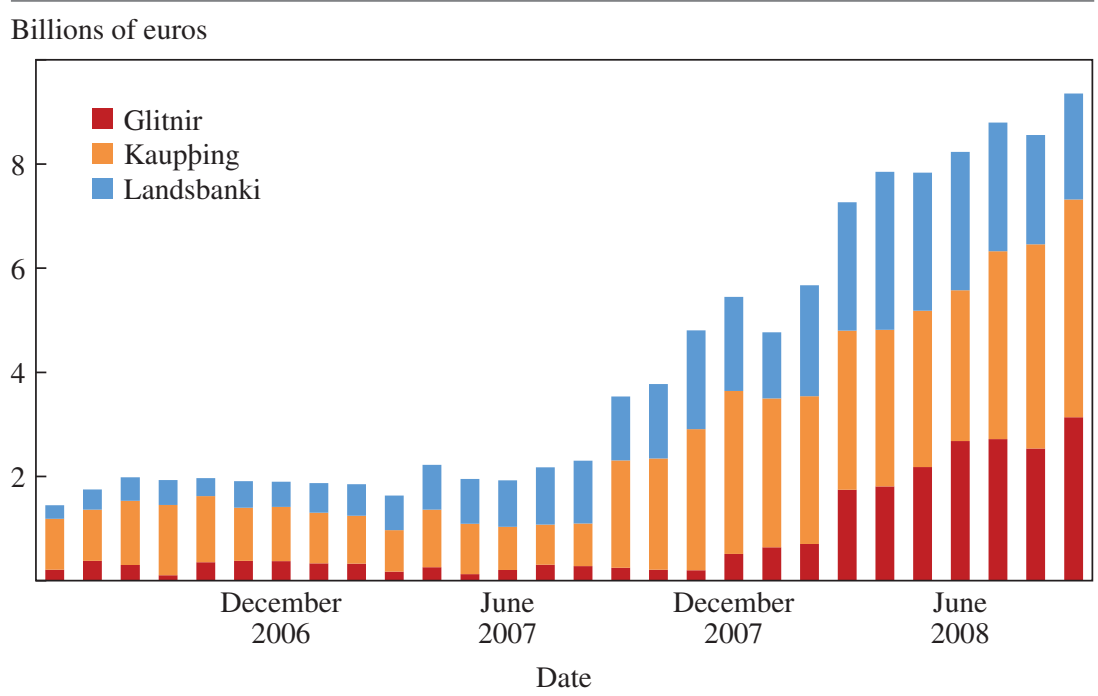

Source: SIC.

Figure 11. Collateralized Borrowing from the European Central Bank by Glitnir, Kaupping, and Landsbanki, January 2008-October 2008

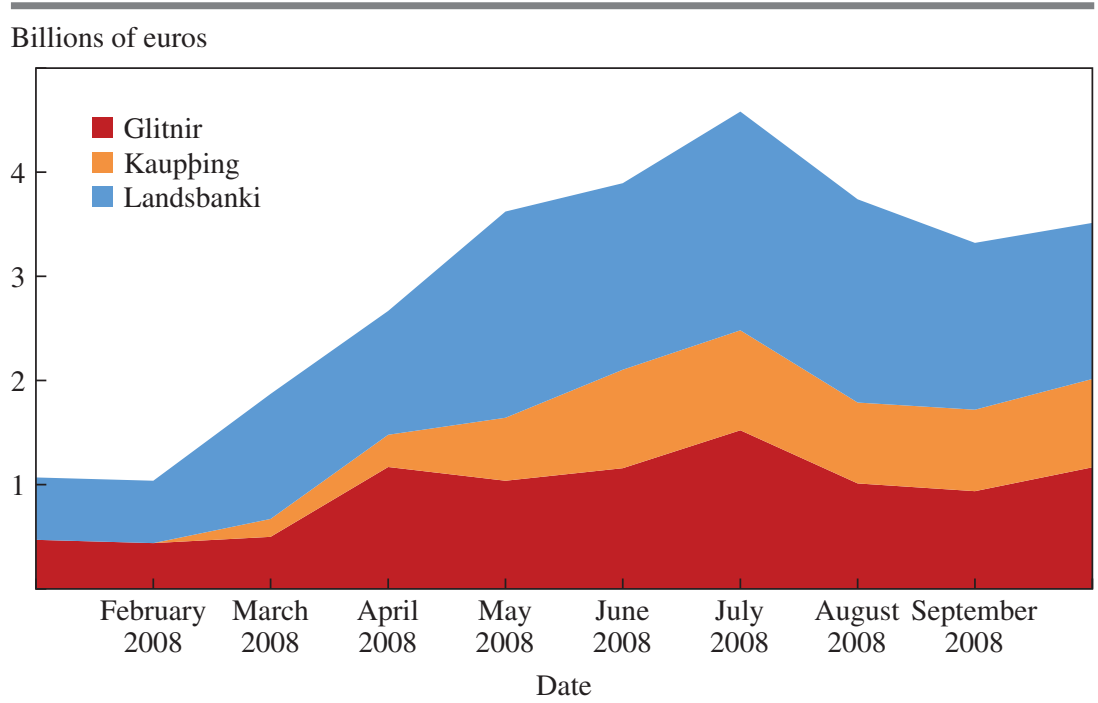

Source: SIC. 
What qualifies as a high-quality bond? As it turns out, the CBI and ECB required such bonds to be above a particular rating threshold, and the pool of eligible assets included bank bonds that met certain ratings criteria. Some central banks, including those of Switzerland and Sweden, explicitly forbid this. As table 3 shows, the Icelandic banks had an excellent credit rating. This opened the door to a straightforward strategy for the closely interconnected Icelandic banks, which became known as the "love letter" exchange.

The love letter exchange worked as follows: Two Icelandic banks issued their own bonds, which they then exchanged, often without going through the financial market. Then the banks posted the respective bonds as collateral for a loan at the CBI or ECB. Because there was no limit to how many bonds they could issue and exchange with one another, the banks essentially had unlimited access to funding from the two central banks. To some extent, this was like printing money (SIC, chap. 4, p. 165; chap. 7, p. 41). ${ }^{13}$

Icelandic borrowing from the ECB via their subsidiaries in Luxembourg increased by $€ 2.5$ billion from the beginning of February 2008 to the end of April 2008, when it amounted to over $€ 3.5$ billion, or more than 20 percent of the combined balance sheets of the Luxembourg subsidiaries of the Icelandic banks (figure 11). ${ }^{14}$ About $€ 1.5$ billion was secured with Icelandic bank bonds, the so-called love letters (figure 12). The ECB got wind of what was going on, and at the end of April 2008, ECB president Jean-Claude Trichet called the governor of the CBI and said that the ECB viewed the bonds posted as collateral as "artificial and abnormal" (SIC, chap. 4, p. 47). The love letter collateral was out of the ECB system by the end of August 2008, replaced in part with CDOs of Icelandic króna-denominated loans swapped into euros with a currency swap agreement written by the Icelandic banks. The CBI, however, continued to take the bank bonds as collateral, essentially giving the banks free access to Icelandic krónur until the bitter end. The CBI's losses were sizable, close to 15 percent of GDP, as we discuss further in section VI.

13. It needs to be noted that such a scheme is not possible in the United States, because the Federal Reserve's open market operations utilize only government securities, rather than collateral posted by banks, to control the interbank lending rate. Direct lending to banks, however, takes place via the discount window, which has strict rules about the type of collateral accepted.

14. Total ECB lending through the Central Bank of Luxembourg amounted to less than 2 percent of the total assets of Luxembourg's banking system at the time (SIC, chap. 7, p. 48). 
Figure 12. Collateral at the European Central Bank, January 2008-October 2008

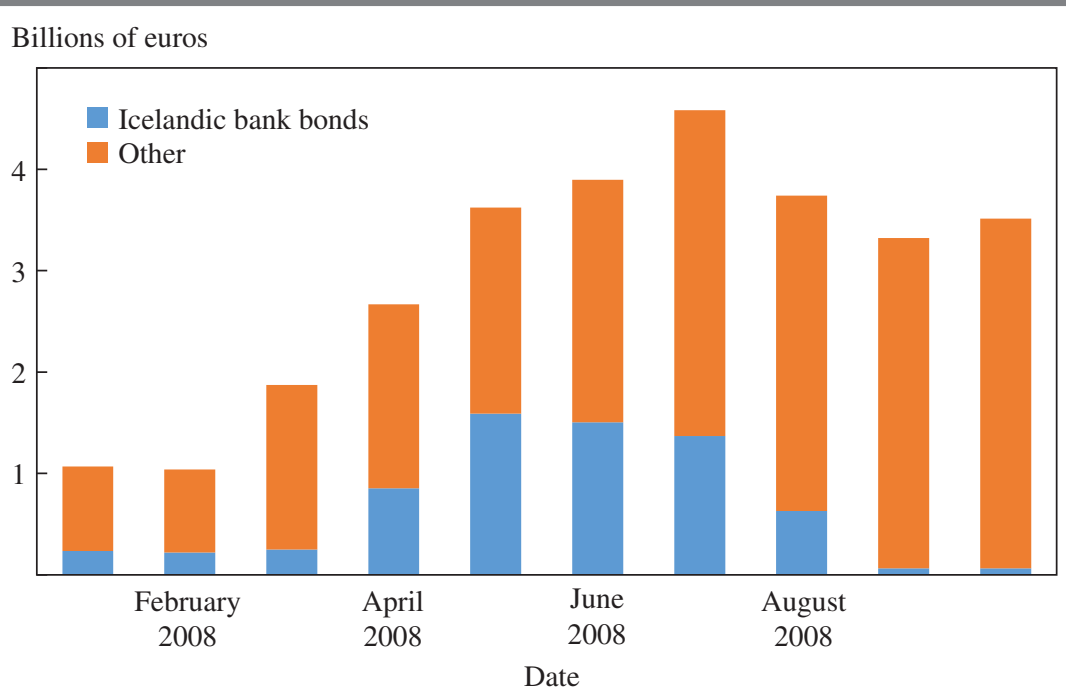

Source: SIC.

There is anecdotal evidence that other European banks engaged in similar behavior to gain access to ECB funding after the liquidity crunch began in 2007. The Icelandic banking crisis, however, to our knowledge provides the only direct evidence for and admission of collusion between banks and a direct swap of bonds to use for collateralized borrowing (SIC, chap. 7, p. 47).

\section{Where Did the Money Go?}

Getting an overview of the loan portfolio of any bank is challenging, not only because of bank secrecy laws but also due to incomplete record-keeping, the complex nature of some loan contracts, and the nontransparent ownership structures of the firms that receive the money. Any assessment will thus necessarily be incomplete and only suggestive. In the case of the Icelandic banks, this is particularly challenging because much of the lending was to holding companies with opaque ownership structures, which were sometimes registered in Iceland but also sometimes held abroad by Icelandic parties, hence connecting back to Iceland. One aspect of the Icelandic banking crisis that makes it of interest, however, is that Alpingi 
lifted bank secrecy laws and other secrecy laws to the SIC, which then made some of the underlying data and conclusions public. We rely on that evidence here, while mostly aggregating the data across all three banks to streamline the narrative.

Before going into the details of the available evidence, and some of the data gaps, it is worth sketching out at a broad level the direction of lending in the run-up to the crisis. The loans that can be explicitly documented appear to have been funneled, to a disproportional extent, to firms and companies that were tightly connected to the banks' owners. At the time of the failure, over 20 percent of the parent banks' loan books, for which reliable information exists, can be traced to only six groups of related parties, each of which had a significant ownership connection to one of the three banks. To remind the reader, what is at stake here is a balance sheet of $€ 115$ billion, or close to nine times Iceland's GDP.

Rules about large exposures stipulate that a bank can only lend up to a maximum of 25 percent of its own funds to a group of connected parties. As is shown below, and as the SIC documented, these rules seem to have been bent if not broken in the run-up to the crisis (SIC, chap. 8). The Icelandic Financial Supervisory Authority (Fjármálaeftirlitið, or FSA), however, never seriously raised the subject of large exposure lending before the financial crisis. The opaqueness of firm ownership limited the FSA's knowledge of the problem, and its narrow legal interpretation of what constituted "connected parties" also played a role. For example, the FSA allowed Landsbanki to categorize the two largest owners of Landsbanki as "not connected," despite the fact that they had purchased the bank together and were father and son (SIC, chap. 8, app. 2). ${ }^{15}$

We mostly focus on the expansion of the three largest banks' combined balance sheet from 2003 to the time of the financial crisis. During this period, their lending increased by $€ 70$ billion, or seven times Iceland's 2003 GDP. We find it useful to separate the expansion of the banks' asset side into two stages: The first stage is lending growth from 2003 to 2006, which funded both domestic and foreign investment by Icelandic investors and holding companies. The second stage was what we call the debt repatriation phase. From 2006 to 2008, Icelandic companies were facing margin calls from

15. Another stark example was that Glitnir did not connect Baugur and Gaumur to Stoðir, despite the former two being very connected and owning more than a 45 percent stake in Stoðir (SIC, chap. 8, pp. 125, 309). Documents indicate that this was done with the sole purpose of getting around rules on large exposures. 
Figure 13. Total Assets of Glitnir, Kaupping, and Landsbanki, 2004:Q1-2008:Q2

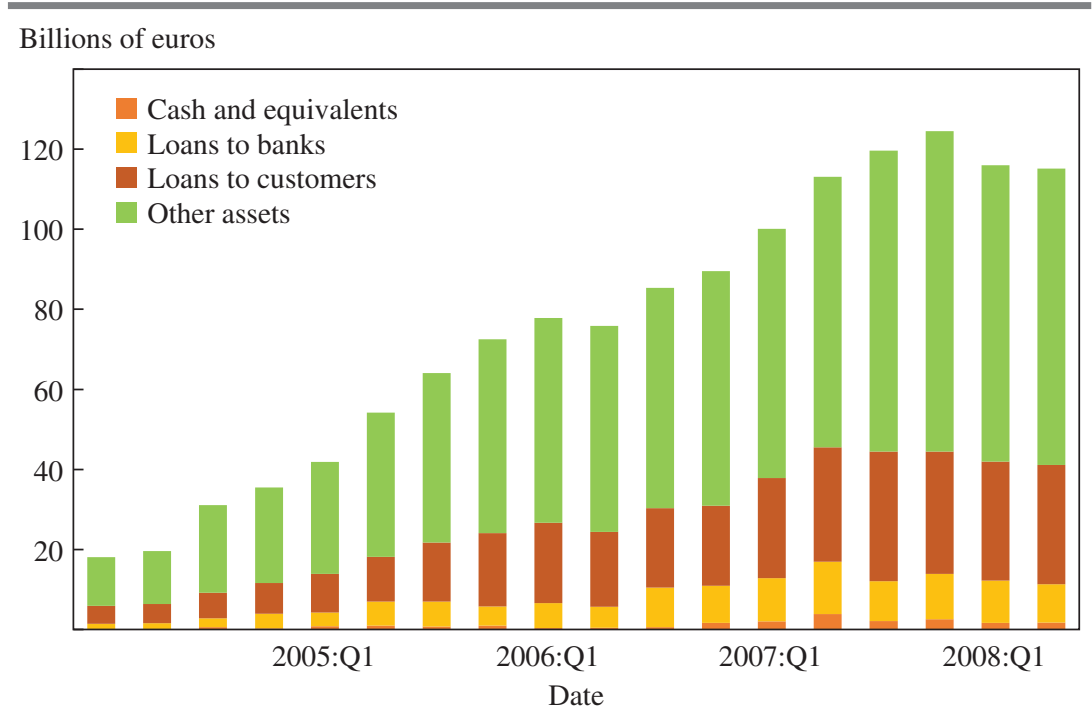

Source: SIC.

their foreign creditors, and these loans were in response refinanced by the Icelandic banks. The lending expansion phase coincides roughly with the banks' successful bond issuance in European and U.S. bond markets (phases 1 and 2, as described in section II), while the loan buyback period corresponded quite closely to the period when the banks started financing themselves with Internet deposits in Europe and with collateralized borrowing from the CBI and ECB.

\section{III.A. The Nature of the Expansion}

Figure 13 shows the evolution of the asset side of Iceland's three largest banks. Their combined assets increased from $€ 18$ billion in the first quarter of 2004 to $€ 115$ billion at the end of June 2008. The largest part of the increase was due to loans to customers, which rose from $€ 12$ billion at the beginning of 2004 to $€ 74$ billion at the time of the banks' failure. ${ }^{16}$

16. The portion of figure 13 denoted "other assets" represents mostly financial assets, securities, and derivatives, but we will mostly focus on the banks' loan books, as the growth is more concentrated there. 
During this period, the Icelandic banks acquired a number of foreign financial institutions, gaining foreign loan portfolios, a fact they used to soothe fears about their rapid growth. This does explain some of their growth, but only a small fraction. Table 4 decomposes the growth during this period. An acquisition of a foreign financial institution or seasoned loan portfolios is an example of "outer growth." Other growth in the banks' lending and other assets is defined as "inner growth." As the table reveals, the largest part of the growth is due to inner growth. Most of the growth on the asset side of the Icelandic banks, in other words, was "fresh" lendingthat is, lending done by the banks themselves, applying their own loan standards to current or new customers. The literature documents that this kind of rapid growth of banks' loan portfolios is associated with increased default risks. There is both a moral hazard effect due to the behavior of overleveraged borrowers and adverse selection in connection with the expansion of banks' customer base (Sharpe 1990; Jiménez and Saurina 2006). The subsequent sections give evidence of both.

\section{III.B. The Erosion of the Loan Books}

As we start to dig into the loan books, the data set contracts. The SIC had unprecedented access to data, but it was still mostly limited to the portions of the banks that were supervised in Iceland-that is, the parent companies, including foreign branches. Detailed information on foreign subsidiaries was limited to single snapshots, shared by foreign supervisors, which did not lend itself to the in-depth analysis given in this section. Figure 14 shows loans from the Icelandic parent companies of the three banks. This reflects about two-thirds of the loan books of the banking groups as of 2008. Some evidence is presented from subsidiaries in Luxembourg, which were the ones that seemed most connected to the operations in Iceland.

The loans shown in figure 14 are categorized into households, firms, holding companies, foreign entities, and other. The "foreign entities" are not necessarily informative about the borrower's actual ownership, because these in some cases included Icelandic investors that registered their companies abroad for a variety of reasons. What is particularly noteworthy is that in 2004, the CBI started tracking loans specifically to limited liability holding companies. There was a sharp increase in these loans in 2006 and 2007. It became increasingly common to use holding companies to fund share purchases in listed domestic firms, particularly in the banks themselves. More often than not, the collateral consisted of shares in the banks themselves, as we discuss below. As figure 15 shows, 


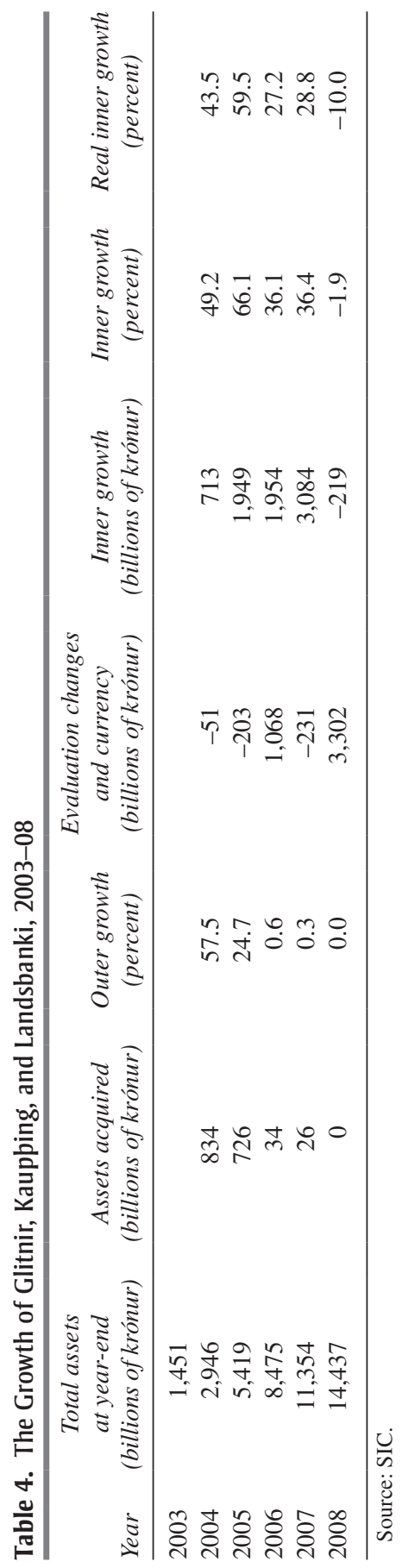


Figure 14. Loans by Glitnir, Kaupping, and Landsbanki, January 2001-September 2008

Billions of euros

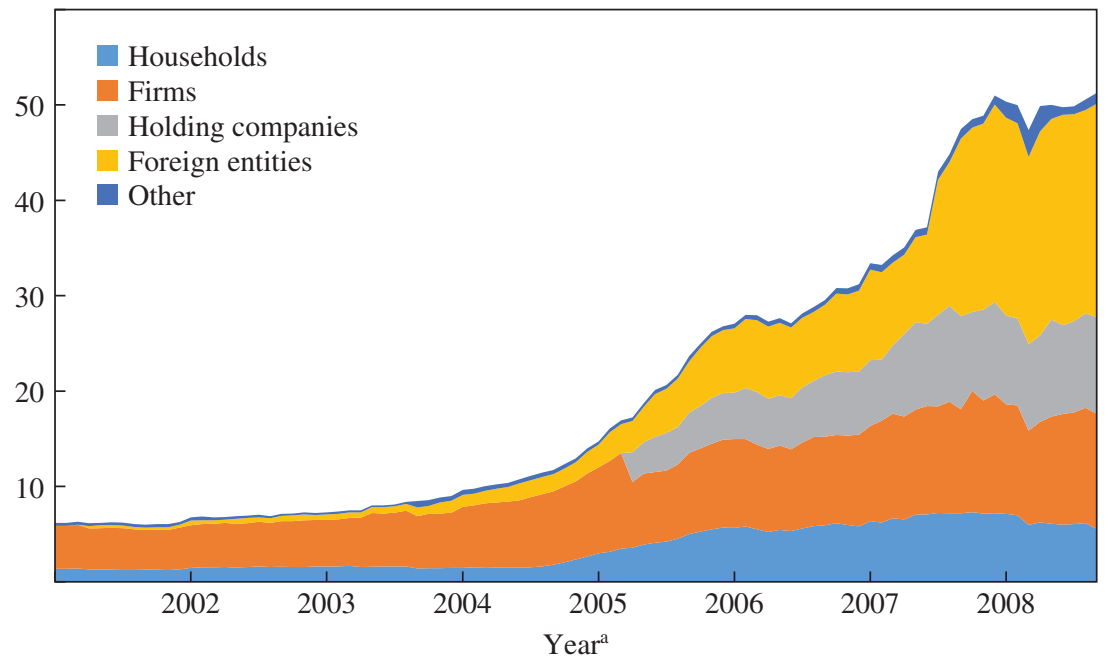

Source: SIC.

a. The data are monthly. The ticks mark January of each year.

Figure 15. Collateral for New Large Exposure Loans, 2007-08

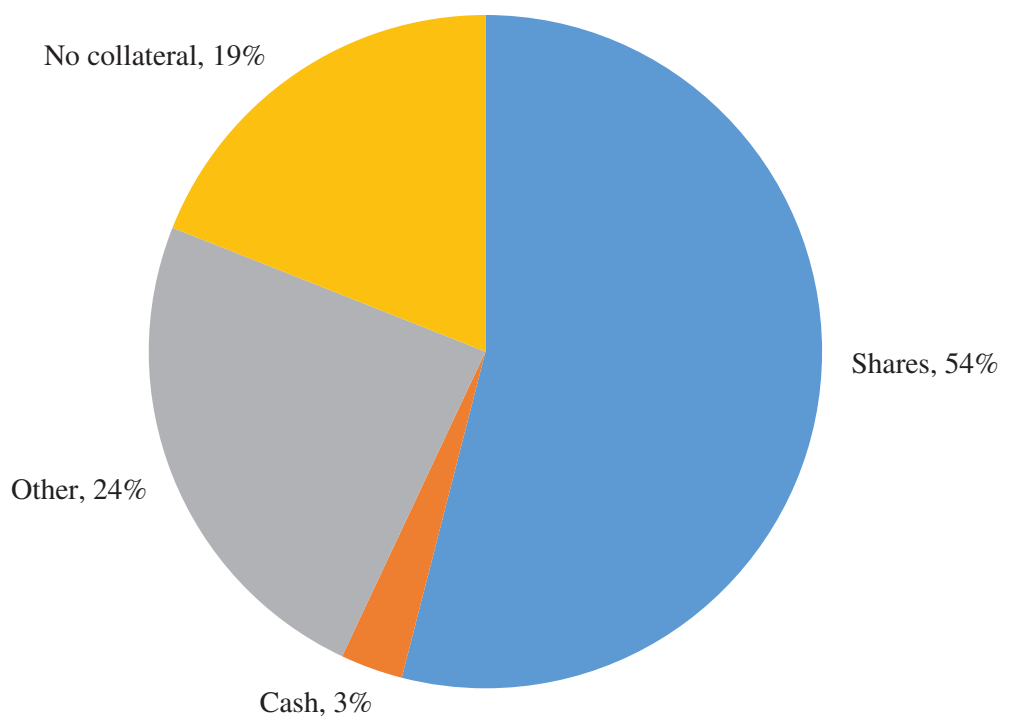

Source: SIC. 
Figure 16. Forms of Loan Repayment by Landsbanki, October 2005-September 2008

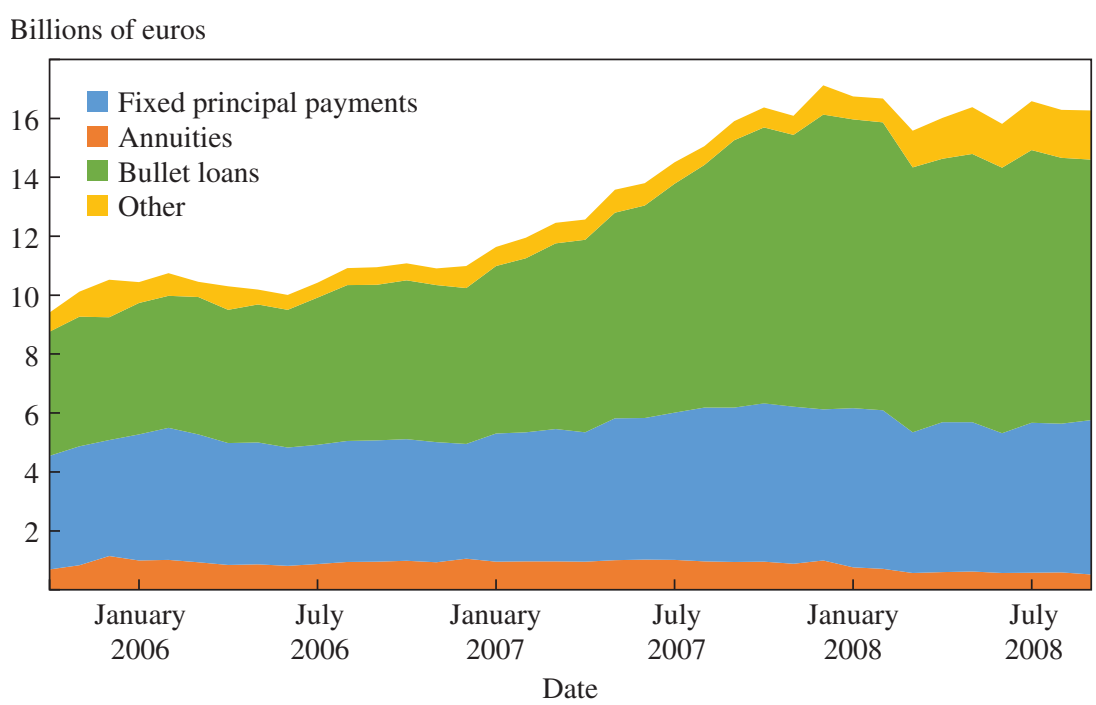

Source: SIC.

54 percent of all the new large exposure loans made from the beginning of 2007 until the collapse in 2008 were collateralized with shares. These loans were also increasingly bullet loans-that is, the entire loan was paid in one installment at the end of the loan period. The loan book of Landsbanki provides a vivid example of this. Figure 16 shows the repayment methods of loans from Landsbanki. Bullet loans doubled from 2006 until the crash, while other types of repayment forms increased only slightly. At the same time, virtually all loans to holding companies were bullet loans starting in mid-2004 (figure 17). This was in sharp contrast to lending to households, for which amortizing loans were most common during the whole period and bullet loans made up less than 10 percent of the total. Bullet loans were also the most common form of repayment methods for loans categorized as having been made to "foreign entities."

Lending that requires only a single payment at the very end of the contract is arguably riskier than the more usual form of loan contracts. The ability to make individual payments sends the banks a signal of the borrower's financial health, but this signal is lost with bullet loans. Supervisors should also view growth in bullet loans as a potential risk, because it is usually the form of loan used to evergreen loans by delinquent borrowers, 
Figure 17. Loans to Holding Companies by Landsbanki, October 2004-September 2008

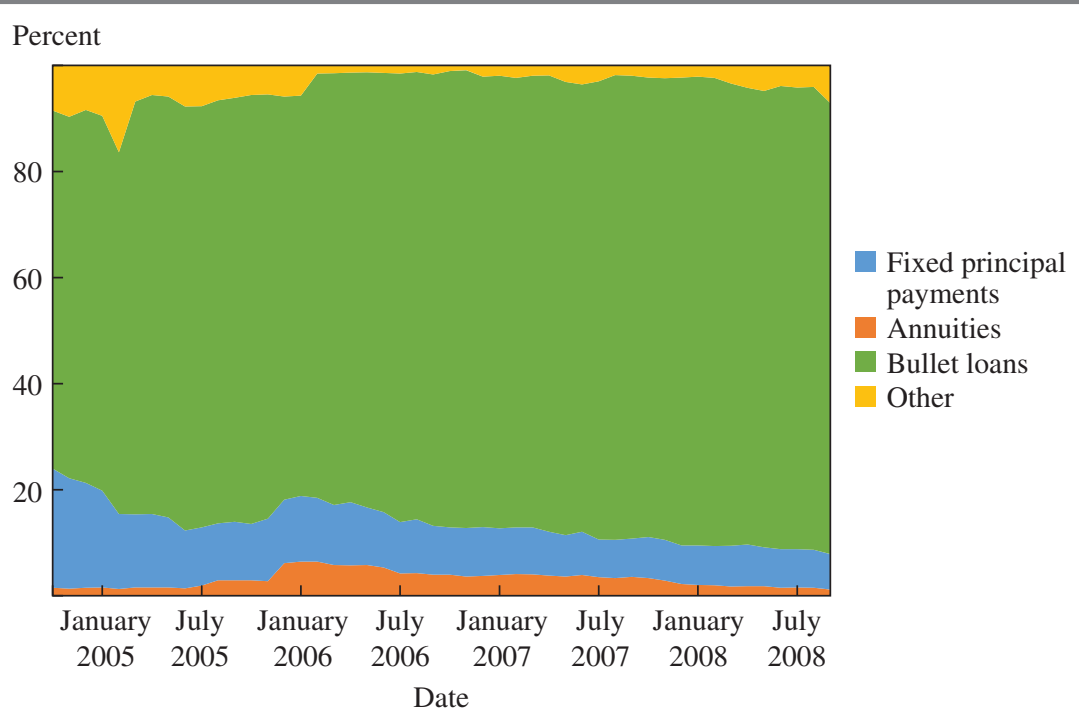

Source: SIC.

so as not to have to register losses on banks' loan books. ${ }^{17}$ The information that can be gleaned from the unwinding of the Icelandic banks after they failed does suggest that these loans were in fact very risky. The estimated recovery rate on loans to holding companies was reported in 2010 to be about 4 percent by Glitnir, while Kaupping reported 6 percent recovery and Landsbanki reported 5 percent. ${ }^{18}$

\section{III.C. Lending to Related Parties and Owners (Insiders)}

Rules about large exposures are almost universal. The Basel Committee on Banking Supervision issued standards in 1991 for measuring and controlling large exposures. The motivation for regulating large exposures is to prevent the sudden failure of a group of borrowers from causing a bank's downfall. The large exposure rules in Iceland stipulated, as they did in most other countries, that each bank could not lend an amount corresponding to more than 25 percent of its capital to one group of related counterparties.

17. The term "evergreen" refers to automatically rolling over a short-term loan.

18. Glitnir, Kaupping, and Landsbanki released this financial information in 2010. 
Figure 18. Kaupping's Large Exposure to Exista and Related Parties, January 2005-September 2008

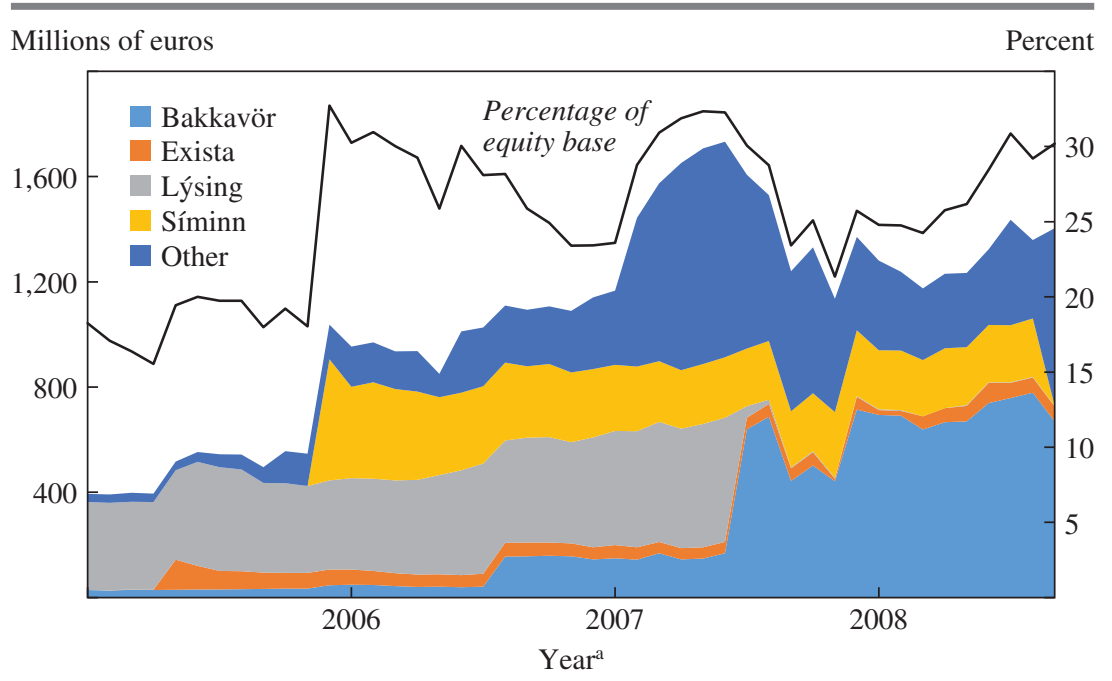

Source: SIC.

a. The data are monthly. The ticks mark January of each year.

However, the large exposure rules were bent to the point of breakage in Iceland, and commonly the owners of the large exposure groups that were able to borrow a lot were also large stakeholders in the banks.

There are two important reason why the rules about large exposures were bent in Iceland without much objection from the supervisory authority. The first is the absence of a clear definition of what constituted a "related party," in both theory and practice. And second, the banks themselves, rather than the FSA, had the last word in determining which loans were deemed to be between related parties. ${ }^{19}$

Figures 18 and 19 show lending by two of the major banks to a group of firms that we, like the SIC, define as "related." ${ }^{20}$ In the case of Kaupping,

19. In principle, the FSA could suggest that certain parties were related, but the burden of proof was on the FSA's side to make the case. This has been amended since the crash, and the FSA now has the authority to require banks to connect specific borrowers to the same exposure.

20. Underlying the two figures are data from the banks' loan books, as well as information about cross-ownership of Icelandic firms, which the SIC put together by using tax data, firm registry data, and minutes from the loan committee meetings of the banks. The SIC then connected firms into groups of related parties; the methodology is outlined by Benediktsdóttir, Bjarnadóttir, and Hansen (2016). Here, two parties are related if they own 20 percent or more of each other-directly or indirectly. 
Figure 19. Glitnir's Large Exposure to Baugur Group and Related Parties, January 2005-September 2008

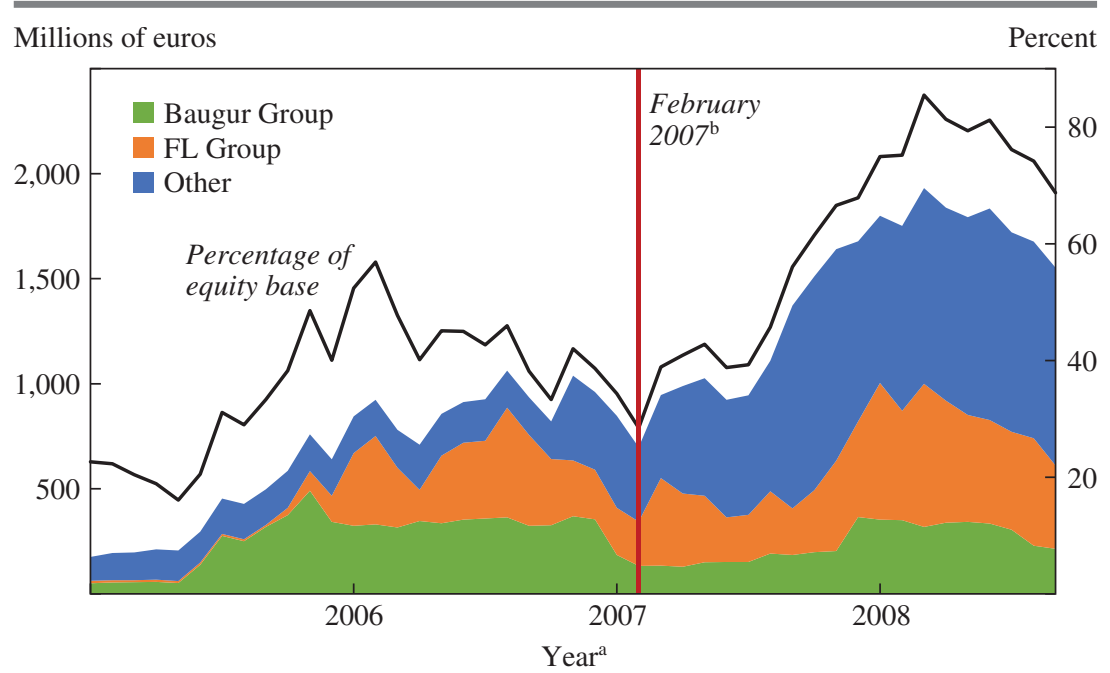

Source: SIC.

a. The data are monthly. The ticks mark January of each year.

b. The vertical line at February 2007 marks when Baugur Group bought a large stake in Glitnir.

the group of related parties exceeded the regulatory limit of 25 percent of the bank's equity base from late 2005 until the bank's failure. In the case of Glitnir, the group of related parties exceeded the regulatory maximum in 2005, and borrowing peaked at close to 90 percent of the bank's equity base in early 2008 .

The banks themselves always reported large exposures within regulatory limits. An employee of the FSA notified its director general as early as 2004 that he thought the banks were not correctly connecting together their large exposures. This employee used Baugur Group and related parties as the main example (figure 19). But the FSA did not follow up on the employee's work, and lending to the group grew exponentially in the subsequent years (SIC, chap. 8, p. 124).

Another noteworthy fact about figures 18 and 19 is that both the related parties in question were also major owners, or insiders, of the banks. ${ }^{21}$ Figure 19 gives circumstantial evidence on the role ownership had in the Icelandic banks. Baugur Group bought a large stake in Glitnir in

21. "Insiders" include executive officers, directors, principal shareholders, and the related interests of such parties. 
Figure 20. Loans to Large Companies and Related Parties That Had Significant Ownership Shares in Glitnir, Kaupping, and Landsbanki, January 2005-September 2008

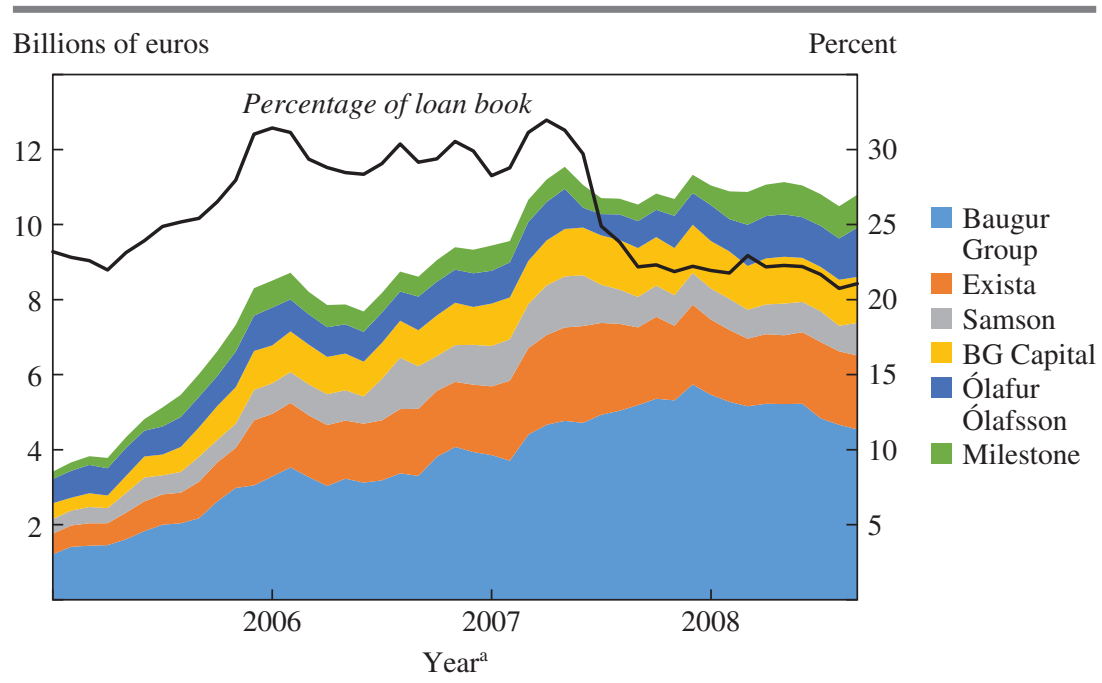

Source: SIC.

a. The data are monthly. The ticks mark January of each year.

February 2007, as shown by the vertical line. Consequently, the loans to the Baugur Group of related parties, which were now insiders, almost doubled, from $€ 1$ billion to about $€ 2$ billion in less than a year (SIC, chap. 8).

In general, the banks' major owners seemed to have had disproportionate access to the banks' funds. Figure 20 illustrates the lending of all three banks to six groups of related parties of borrowers that were also directly or indirectly owners of the banks, shown both in billions of euros (left axis) and as a portion of the total loan book (right axis). When the banks failed, lending to these six groups corresponded to over 20 percent of the parent bank's loan book.

Considerable literature exists documenting how lending to insiders weakens banks due to tunneling and looting (Akerlof and Romer 1993; Johnson and others 2000). As has been shown, it seems that lending to insiders in Iceland was on an exceptional scale. Yet it is worth keeping in mind that there are several other well-documented examples of major-owner insider lending. In the years before the Mexican banking crisis of the 1990s, for example, insider lending was estimated to be 20 percent of all loans (La Porta, Lopez-de-Silanes, and Zamarripa 2003). Insider lending was also an important factor in the savings and 
Table 5. The Ten Largest Debtors of the Icelandic Banks' Parent Companies and Their Debt in Two Subsidiaries, September 2008

\begin{tabular}{|c|c|c|c|c|c|}
\hline Rank & Name & $\begin{array}{c}\text { Debt in parent } \\
\text { company } \\
\text { (millions of } \\
\text { euros) }\end{array}$ & $\begin{array}{c}\text { Debt in } \\
\text { Luxembourg } \\
\text { subsidiaries } \\
\text { (millions of }^{\text {euros) }}\end{array}$ & $\begin{array}{l}\text { Rank } \\
\text { in loan } \\
\text { book }^{\mathrm{c}}\end{array}$ & $\begin{array}{c}\text { Total debt } \\
\text { (millions } \\
\text { of euros) }\end{array}$ \\
\hline 1 & Robert Tchenguiz & $2,105.9$ & 213.0 & $3(\mathrm{~KB})$ & $2,317.9$ \\
\hline 2 & Ólafur Ólafsson & $1,128.2$ & 49.1 & $10(\mathrm{~KB})$ & $1,177.3$ \\
\hline 3 & $\begin{array}{l}\text { Jón Ásegeir } \\
\text { Jóhannesson }\end{array}$ & 864.3 & 11.5 & $9(\mathrm{LB})$ & 875.8 \\
\hline 4 & $\begin{array}{l}\text { Björgólfur } \\
\text { Guðmundsson }\end{array}$ & 516.8 & 16.5 & $5(\mathrm{LB})$ & 533.3 \\
\hline 5 & $\begin{array}{l}\text { Björgólfur T. } \\
\text { Björgólfssson }\end{array}$ & 481.7 & 305.0 & 1 (LB) & 786.7 \\
\hline 6 & Ása K. Ásgeirsdóttir & 430.6 & & & 430.6 \\
\hline 7 & Jóhannes Jónsson & 429.7 & & & 429.7 \\
\hline 8 & $\begin{array}{l}\text { Hannes fiór } \\
\text { Smárason }\end{array}$ & 410.6 & & & 410.6 \\
\hline 9 & $\begin{array}{l}\text { Ingibjörg Stefanía } \\
\text { Pálmadóttir }\end{array}$ & 390.7 & & & 390.7 \\
\hline 10 & Jákup á Dul Jacobsen & 349.8 & & & 349.8 \\
\hline
\end{tabular}

Source: SIC.

a. Debts are tabulated from the personal holdings of the individual in the banks. Ownership is assessed from holdings at the end of 2008 .

b. Data for the Luxembourg subsidiary of Landsbanki are from October 2, 2008. Data for the Luxembourg subsidiary of Kaupping are from August 31, 2008.

c. Kaupping is abbreviated KB, and Landsbanki is abbreviated LB.

loan crisis in the United States (Calavita, Tillman, and Pontell 1997; Akerlof and Romer 1993).

\section{III.D. Lending Traced to Individuals}

Another way of characterizing lending to "related parties" is to identify it with particular underlying individuals. If firm A secures a loan of, say, $€ 100$ million from a bank, and a particular individual holds a 10 percent share in firm A, then $€ 10$ million of the loan is assigned to his or her name. The SIC traced every loan from the parent banks through firms down to individuals and made the results public (table 5).

The SIC did not have access to the loan books of the banks' subsidiaries abroad. One might suspect—and indeed, the Icelandic banks claimed this before their failure-that the loans of their subsidiaries abroad would diversify the risk. The SIC did get a snapshot of the largest borrowers from the Luxembourg subsidiaries of Landsbanki and Kaupping. Once again, it was the banks' main owners - their insiders - that were borrowing heavily, 
even in foreign subsidiaries. We add this to the parent companies' loan books in the table. Done in this way, we see that the top five borrowers are also among the largest shareholders in the Icelandic banks. Several of the others on the list are also closely related. ${ }^{22}$

\section{III.E. Debt Repatriation}

The discussion above points to a deterioration in the Icelandic banks' loan books from overexposure to certain groups of related parties and to the banks' owners. An additional mechanism of increased credit risk is worth noting. Access to international financial markets was not just opening up for the banks in the period from 2003 to 2006. Icelandic bank holding companies were also gaining increased access to funds in large international banks—such as Barclays, Citibank, Morgan Stanley, and Deutsche Bank. Often, these loans were collateralized with Icelandic publicly traded shares, in particular shares in the Icelandic banks. The loans usually included stipulations that the debtor needed to post further collateral if the shares fell enough in value (margin calls). ${ }^{23}$

This situation had major implications as the global liquidity crisis hit in the middle of 2007 and share prices of banks around the world started to decline. Foreign banks started to send out margin calls to Icelandic holding companies and investors, which turned to the Icelandic banks to refinance their loans (SIC, chap. 8). Despite the liquidity tightness they were experiencing, the Icelandic banks took on the challenge, and doubled down on lending to their customers, repatriating the credit risk that had formerly been diversified out of the country. This concentrated the risk to which the banks were exposed and increased the economy's overall systemic risk. There were a number of plausible reasons why the banks may have done this. For one, the borrowers were more often than not also large stakeholders in the banks, calling into question the principle of arm's length lending. In addition, the Icelandic banks had extended so much credit to the same holding companies that their default would have a substantial effect on the

22. Tchenguiz owned shares in Kaupping and was on the board of Exista, which was a major owner of Kaupping. Ólafsson was a major owner of Kaupping. Jóhannesson was a major owner of Glitnir. Gudmunðsson and Björgólfsson—father and son-were major owners of Landsbanki. Ásgeirsdóttir is the mother of Jóhannesson, Jónsson-a major owner of Glitnir—is his father, and Pálmadóttir was his spouse. Jacobsen had no known ownership connection.

23. The SIC gave an example of three deals with lending over $€ 600$ million. It was also common for the loans from foreign banks to have a priority claim over the Icelandic loans in case of default-for example, loans to the pharmaceutical company Actavis. 
banks' operating results. Hence, these borrowers had become "too big to fail" for the Icelandic banks, or there was a kind of "bank capture." Finally, the collateral that foreign banks would have seized and sold was in many cases made up of shares in the banks themselves, so a default to the foreign creditor would have triggered a sell-off of the banks' stocks, further reducing their stock value and complicating the banks' international funding. Thus, the Icelandic banks were left with two bad choices: doubling down on an overleveraged customer, or risking the effect of their failure. They chose the former, increasing the risk for the bank and the economy as a whole. This behavior is reminiscent of Rajan's (1994) model of credit policy under incomplete information, which explains why banks may extend loans with negative net present value. Instead of maximizing long-term performance, the bank manager is more concerned with information that is directly observable by the market, such as share prices.

\section{III.F. Transparency and Ownership Structure}

It is worth stressing that the information about lending to related parties relies upon the extensive work of untangling several holding companies with various types of cross-ownership that was possible only after bank secrecy laws were lifted and the SIC gained access to all tax returns. Few of these connections were known before the crisis. Figure 21 shows the complex cross-ownership of the 1,307 Icelandic firms with balance sheets in excess of 500 million krónur at the end of 2007. Most of these were holding companies that had little or no equity, and many were established explicitly to circumvent regulations of related parties. But even what became known, and what we have documented above, is still only a partial picture. Bank secrecy laws were only lifted in Iceland, and therefore it was often impossible to trace aspects of a financial relationship and firm ownership across borders. It is important to be able to trace firms' ownership to prevent too much interdependence, too much insider lending, and violations of rules about large exposures - all of which are crucial for financial stability and bank supervision.

\section{A Fable of Fictional Equity}

When a bank fails, those who hold equity in the bank will not get anything paid out until all other claims have been settled. Consider the stylized example of a bank's balance sheet, showing assets and liabilities, given in table 6 . This bank has a 10 percent equity-to-assets ratio, or what is termed its capital adequacy ratio, assuming 100 percent risk weights for all its 
Figure 21. The Interconnectedness of Icelandic Firms with More Than 500 Million Krónur in Assets

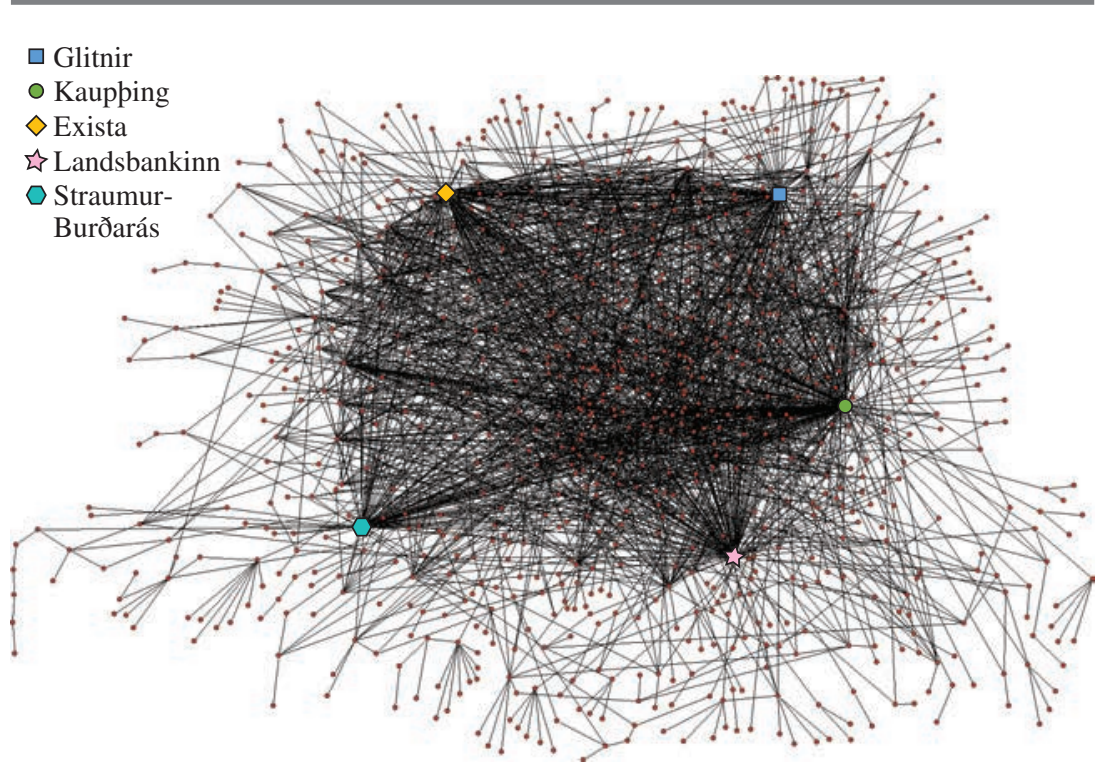

Source: SIC.

assets-or, alternatively, a 10 percent leverage ratio. Now consider a scenario in which loan defaults increase to the extent that there is a 20 percent decline in the value of the bank's loan book, which goes from $\$ 100$ to $\$ 80$, rendering the bank insolvent. Depositors and other creditors would recover 89 percent of their claims in this case, even though the loan book's value has declined 20 percent. Because the bank's main loss-absorbing buffer, its equity, has been wiped out in this example, the bank's shareholders will lose all their money. Sufficiently high equity is thus the key for a bank to remain resilient. For example, if the bank's equity had been $\$ 20$ rather than $\$ 10$, then even a 20 percent drop in the value of its assets would have left its depositors and other creditors fully protected, and the bank would still have been technically solvent.

Table 6. Example of a Balance Sheet

\begin{tabular}{|c|c|c|c|}
\hline Assets & & Liabilities & \\
\hline \multirow[t]{3}{*}{ Loans } & 100 & Deposits & 75 \\
\hline & & Other liabilities & 15 \\
\hline & & Equity & 10 \\
\hline
\end{tabular}


Figure 22. Capital Adequacy Ratios for Glitnir, Kaupping, and Landsbanki, November 2006-June 2008

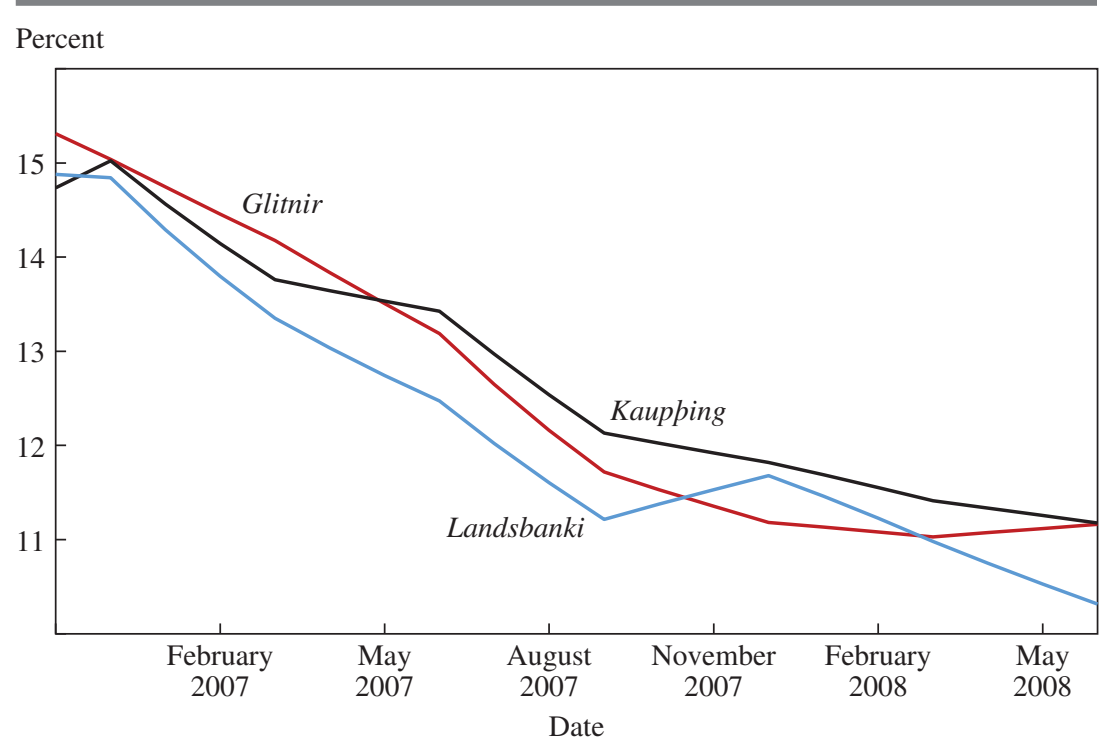

Source: SIC.

For this reason, most countries have minimum equity requirementsthat is, a bank's equity cannot go below a certain threshold relative to its total (or, more generally, risk-weighted) assets. In Iceland, the legal requirement in the years before the crisis was 8 percent risk-weighted capital, in line with Basel I. The Icelandic banks always met this requirement; even three months before their failure, they were apparently well above it. Figure 22 shows the banks' capital adequacy ratios.

Now imagine two banks, $\mathrm{K}$ and $\mathrm{L}$, with identical balance sheets, as shown in table 6 . As before, there is a 10 percent non-risk-weighted capital ratio. This provides depositors and other creditors with a cushion in case of bank failure. Now imagine that the two banks are sold at book value to two investment groups, A and B. Suppose, furthermore, that in order to finance the purchase, the new bank owners borrow from each other's banks the entire purchasing amount, or $\$ 10$. Suppose the only collateral for these loans are the shares in the bank being purchased. Now, on the asset side, $\$ 10$ out of the $\$ 100$ in the "loan book" is a loan to the owners of the other bank.

What is the problem with this arrangement? Consider a situation in which the loan book declines $\$ 20$ in value for both banks, rendering them insolvent. The value of their equity becomes $\$ 0$, and both banks then 
immediately lose another $\$ 10$ from the loans they have collateralized in bank equity. This means that an additional $\$ 20$ of the banks' combined balance sheet gets wiped out immediately. The aggregate banking system is left with no equity and higher losses for creditors. The recovery for depositors and other creditors will be 78 percent instead of 89 percent with this kind of cross-lending. Indeed, this is equivalent to the losses that would be incurre if both banks had no equity at all. ${ }^{24}$ Accordingly, cross-borrowed bank equity provides no cushion to depositors and other creditors in case of an asset value decline and system-wide bank failure.

The same principle applies, but with even more force, if a bank lends money to a person to buy its own shares if the only collateral is the share itself. In this case, the equity is not only fictional in case of a system-wide failure; it also provides no protection in the case of a failure of that individual bank. As the bank fails, the asset in the loan book corresponding to loans for share purchases immediately gets wiped out.

These simple examples are relevant in the Icelandic case. After the banks' failure, and the opening up of the loan books, it turned out that from the time of their privatization onward, their shares were heavily funded via loans from themselves and each other, as we discussed above (figure 23). This meant that, in the aggregate, the banking system had very little equity from the beginning. In addition, the three large banks did extensive lending to purchase their own shares before the crisis. By the middle of 2008, they were funding, on average, 25 percent of their own shares; and if we include cross-funding, they were funding 33 percent of the shares in the three largest banks. ${ }^{25}$ This amounted to about $€ 4$ billion. These loans became worthless when the banks failed, giving the equivalent outcome for depositors and other creditors as if that equity had never been there as a buffer against losses. The capital adequacy ratio for the banks was hence overestimated in the middle of 2008. The loss-absorbing capital buffer was only about 8 percent, rather than the 11 percent reported by the banks (SIC, chap. 9, p. 22).

One of the motivations for a bank to fund its own shares was market manipulation. Once the liquidity crisis started in the summer of 2007, the banks' share prices came under severe pressure. The banks all reacted in the same manner: They purchased about 50 percent of all trades with their shares that came through the stock exchanges. As can be seen in figure 24,

24. Assets would be $\$ 90$, deposits and other liabilities would be $\$ 90$, and equity would be $\$ 0$; so with $\$ 20$ in initial loss recovery for depositors, other liabilities would be $\$ 70$ / $\$ 90=78$ percent.

25. Subordinate debt accounted for about half the banks' capital, so this was about a sixth of the banks' total capital. 
Figure 23. The Banks' Funding of Their Own Shares and Cross-Funding of Shares, December 2006-June 2008

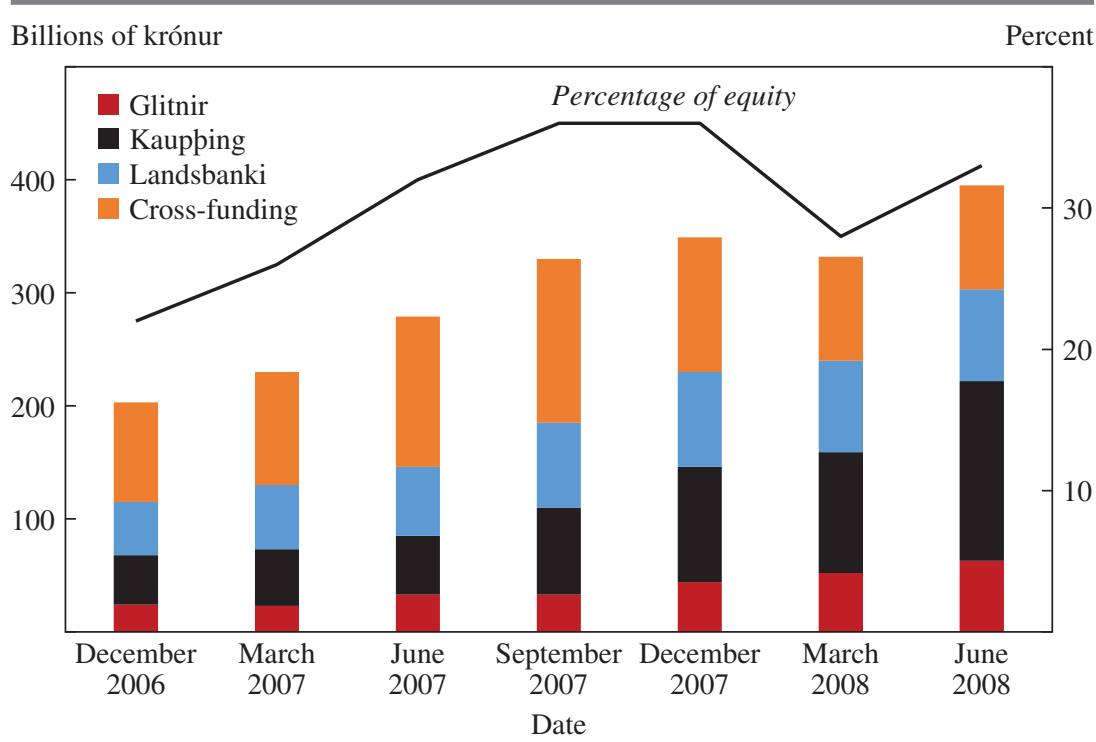

Source: SIC.

Figure 24. Kaupping's Participation in Trades Involving Its Own Shares and Kaupping's Share Price, January 2004-September 2008

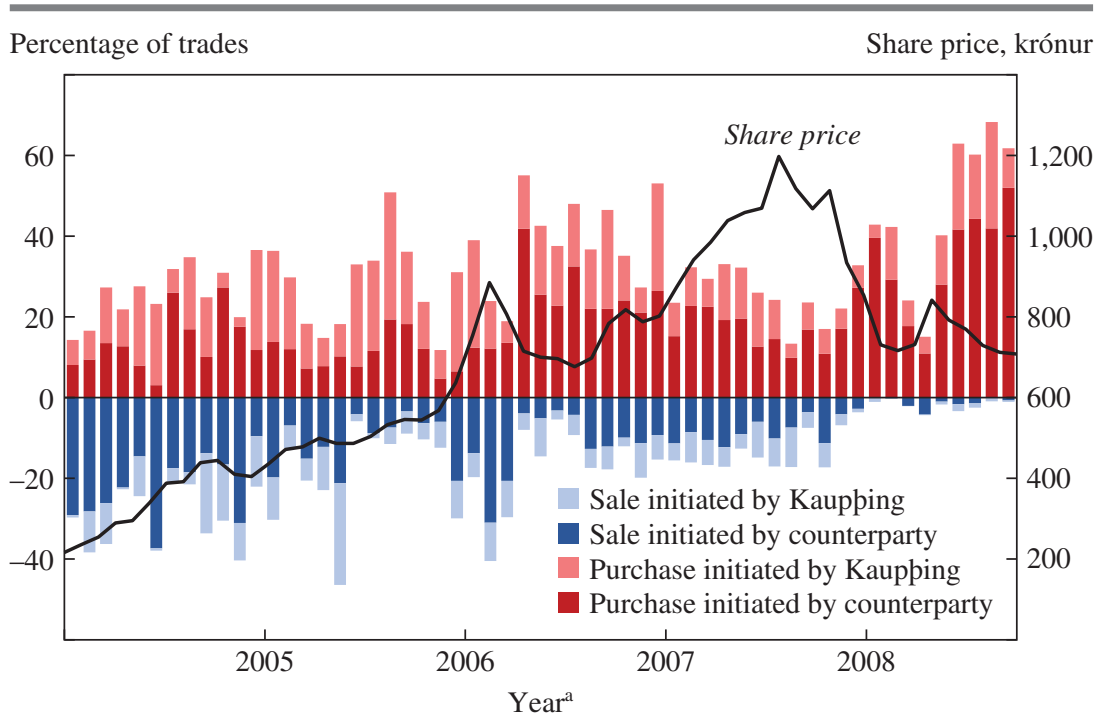

Source: SIC.

a. The data are monthly. The ticks mark January of each year. 
this reached up to 70 percent of all trades with the shares of Kaupping in the last months before the bank's failure. The same story holds for the other two banks. In total, the banks purchased their own shares on the stock exchanges for over $€ 3.5$ billion in the last 20 months before their failure, while they only sold less than $€ 0.5$ billion of their shares on the exchanges. The banks could not own these shares due to rules that limited ownership of own shares, so they sold them over the counter, outside the stock exchanges, to holding companies, which were often owned by insiders or large customers. These sales were frequently coupled with a loan amounting to the full purchase price of the shares. The only collateral for the loan were the shares themselves (SIC, chap. 12). In a subsample of the largest loans, 32 firms borrowed $€ 3.5$ billion over the same 20 -month period to fund share purchases. ${ }^{26}$ As the crisis intensified, it was clear that these loans were not handled like loans for unrelated shares. For instance, the banks repeatedly waived margin calls (SIC, chap. 12, p. 17). The SIC report goes step by step over a number of these deals, which were obviously made in an attempt to manipulate the banks' market price. Additionally, this process increased systemic risk, as the equity of the banks became fictional, and thus it lost its loss-absorbing capacity. The managers of two of the three banks have been found guilty by the Icelandic Supreme Court of market manipulation, and the third case is now being prosecuted. ${ }^{27}$

This practice of a bank lending for its own shares was not limited to Icelandic banks. In Ireland, for instance, there was a high-profile case about lending to the so-called Golden Circle, or Maple 10. Anglo Irish Bank lent $€ 450$ million to 10 investors for them to reinvest in the bank's shares to bolster its share price (Crimmins, Gergely, and Saul 2009). This amplified the Irish government's loss from the banking crisis. Similarly, Britain's Serious Fraud Office (2017) charged four senior executives of Barclays for extending loans to investors to buy its own shares so as to prop up its stock price. The investor, who was not accused of wrongdoing in this case, was also involved in a similar market manipulation trade with Kaupping.

Doubling down on overleveraged customers and manipulating share prices - as well as international credit default swap prices ${ }^{28}$ — were signs that Iceland's banks were "betting on life" or were "gambling for resurrection," a common theme in the finance literature. When a bank runs the risk of

26. These loans were not only for shares sold by the banks; some of them were also loans to refund the foreign loans discussed in the previous section.

27. The Supreme Court convicted executives of Landsbanki in case no. 842/2014 (February 4, 2016) and executives of Kaupping in case no. 498/2015 (October 6, 2016).

28. The banks did this through Deutsche Bank. 
becoming insolvent, bankers often shift their risk-taking to projects with low or negative expected returns if there is a small probability that the returns will be high. If the gamble fails, the shareholders will lose; if it succeeds, the bank may survive (Boyd and Hakenes 2014). As we have explained, the banks in Iceland increased their risk-taking in many ways, at subsequent great cost. In retrospect, this behavior became increasingly earnest—and obvious—after the liquidity crisis hit in the middle of 2007.

\section{The Failure of the Icelandic Banks}

So far, we have not much discussed the fact that Iceland has its own currency, the króna. The reason for this omission is not because we think it is unimportant. Rather, we think that the euro-denominated view gives a more precise understanding of Icelandic banks' balance sheets in the years before the 2008 global financial crisis, given that it involved the expansion of their assets and liabilities, a large portion of which were denominated in euros.

The króna, however, is critical for understanding the Icelandic banks' actual failure. The banks were increasingly operating in foreign currencies, but with no credible lender of last resort in those currencies. The CBI's foreign currency reserves were a tiny portion of the short-term foreign liabilities of the Icelandic banking system. Foreign currency deposits alone were as high as eight times the central banks' reserves (SIC, chap. 7). The banks were thus susceptible to a classic bank run, as described by Diamond and Dybvig (1983). Interestingly, the banks in fact failed with their coffers full of krónur, which, as we have documented, they could essentially print at will, via the "love letter" trade documented in section III. But the banks lacked foreign currency to service foreign depositors and claimholders once they came asking for their money back. Therefore, in documenting the collapse of the Icelandic banks, we begin by giving a snapshot of the aggregate financial flows in the years before October 2008, explaining how the banks' external debt position played a role in the financial crisis. We return to this issue in section IX.

Between 2002 and 2008, investment in Iceland increased by more than 6 percent of GDP, private consumption increased, and savings contracted by 13.5 percent of GDP, resulting in the country's current account deficit peaking at almost 25 percent of GDP in 2006, as shown in figure 25. This deficit was financed by international financial markets, mostly through the domestic banking system, as we have documented in section II. Direct borrowing in bond markets, collateralized borrowing, and deposits, as 
Figure 25. Iceland's Current Account Balance, 1997-2016

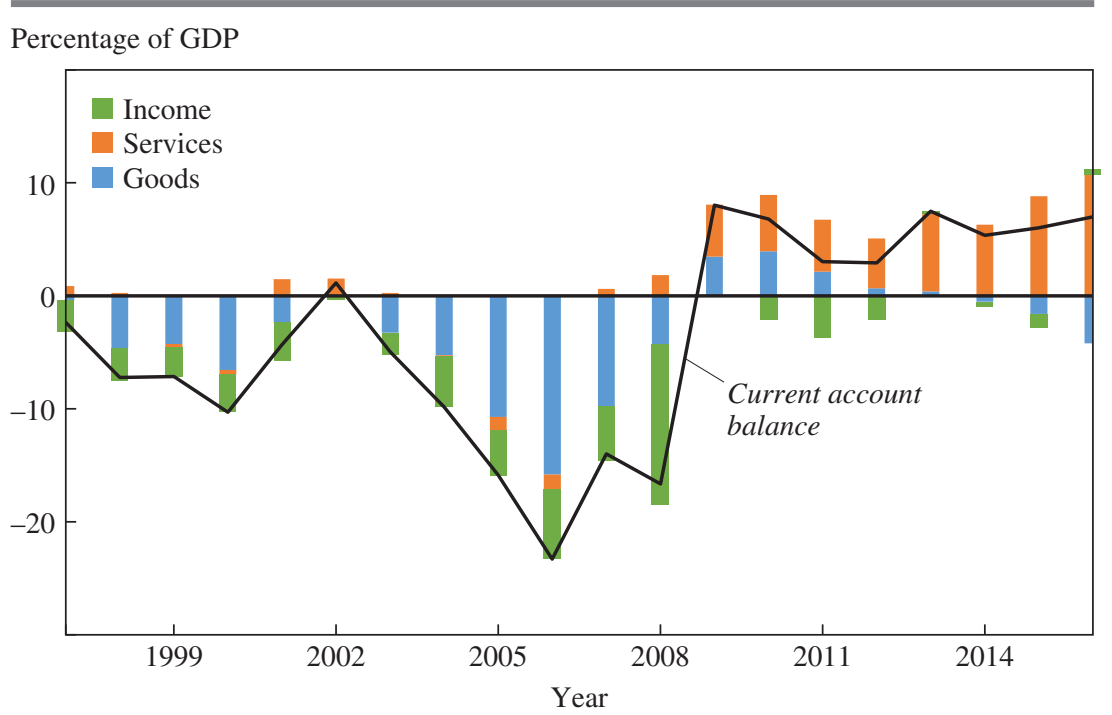

Source: CBI (2017b).

mentioned above, funded loans in foreign currency to Icelandic households and firms, which sometimes had neither assets nor income in foreign currencies. The portion of loans to households that were denominated in foreign currency rose from virtually zero in 2004 to close to 18 percent at the time of the banks' failure (figure 26). On the firm side, it rose from 55 percent in 2004 to over 60 percent at the time of the failure.

Another source of capital inflows was the carry trade, which was attracted by a wide interest rate differential and investors' expectations of a currency appreciation. By mid-2007, the stock of outstanding "glacier bonds"bonds issued abroad in Icelandic krónur, and hedged with domestic liabilities, including bonds and derivatives — amounted to about a third of Iceland's GDP. Iceland looked like a classic example of a "capital flow bonanza," as described by Reinhart and Reinhart (2008). The likelihood of capital flight was far from trivial.

In this respect, the Icelandic financial crisis looked much like the Asian financial crisis of the 1990s. There was an economic upswing, inducing an increase in interest rates to combat inflation. Interest rate differentials became quite high, capital inflows increased quickly, and the Icelandic banks borrowed heavily abroad to funnel funds to domestic firms and households. The capital inflow bonanza increased the likelihood of a financial crisis, 
Figure 26. Loans to Firms and Households in Foreign Currency, 2004:Q1-2008:Q3

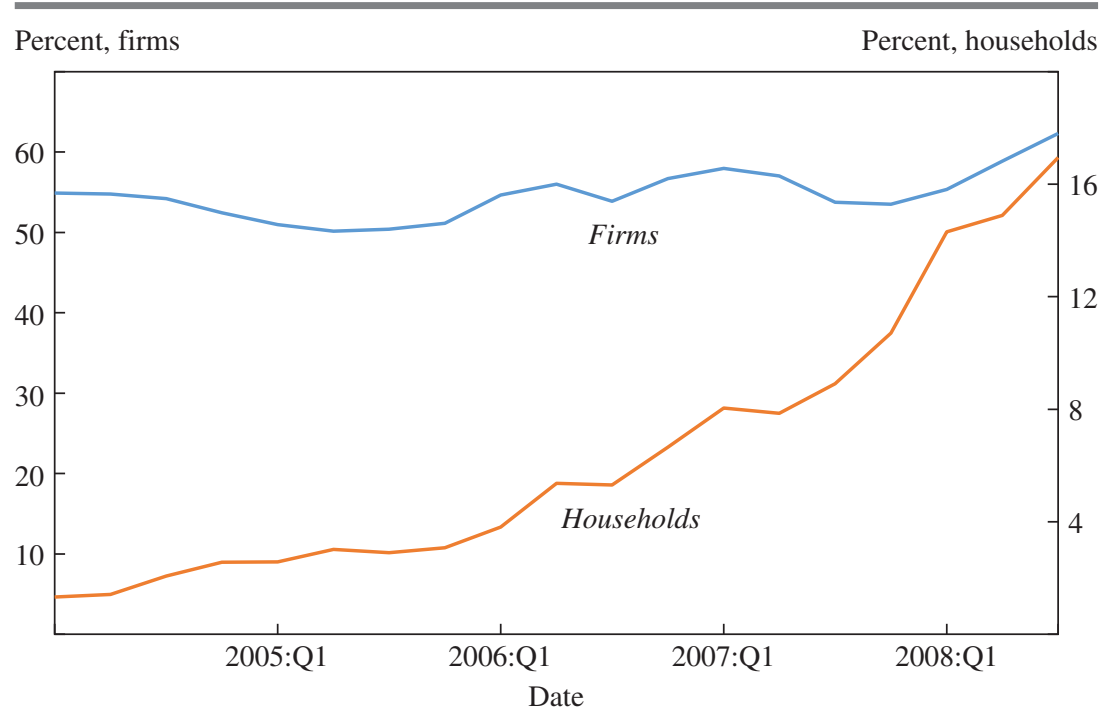

Source: CBI.

which would then threaten the solvency of overleveraged local governments, firms, and households.

As the liquidity crisis struck in 2007, it became harder for the banks and other Icelandic firms to secure foreign funding, and the Icelandic króna started to give way. In about the middle of September 2008, after many months of trying to find foreign funding, it became clear that Glitnir would not be able to pay off a large loan maturing in October. The head of Glitnir's board requested assistance from the CBI on September 25. On September 29, it was publicly announced that the government was taking over 75 percent of Glitnir's equity (BBC 2008). This rattled the international financial markets, which had already been plenty rattled after the failure of Lehman Brothers. The markets did not see this move by the Icelandic government as credible, given the size of the banking system and the currency in which it operated. A full-fledged capital flight from Iceland ensued. Share and bond markets were in free fall, as both domestic and foreign investors ran for the door. The banks' share prices declined, margin calls were coming in for collateralized borrowing, liquidity lines turned out to be not liquid at all, and a run on foreign deposit accounts was growing increasingly intense. The banks were fast becoming illiquid in foreign currencies (SIC, chaps. 4 and 20). 
On October 6, 2008, Alpingi passed the Emergency Act. ${ }^{29}$ The act had two major features. First, it changed the order of priority for claimholders by giving depositors first priority. Before the law, depositors had the same priority as other unsecured claims, such as bondholders. Second, the act granted the FSA broad-based and unprecedented authorization to intervene in various ways in the operations of financial undertakings. The FSA took over all three banks that same week..$^{30}$

The FSA split each bank in two, as illustrated in figure 27. It created a domestic bank that took over all deposits in Iceland, which were guaranteed in full. Most of the Icelandic assets were transferred to the new banks, at a hefty discount, as we discuss in section VI. The government refinanced the new banks with equity injections and subordinated loans, amounting to about 12 percent of GDP. The government then took partial ownership of the new banks, according to the amount of refinancing that it had provided. The rest of the assets and liabilities were left in three holding companies, usually called the "old banks," which were directed by resolution committees tasked with protecting creditors' interests; and winding-up boards were appointed to file claims. As a consequence, the operation of the banks in Iceland was never interrupted.

An immediate issue of contention in these very first days was the demand by the British and Dutch governments that the Icelandic government guarantee the EU-mandated deposit insurance for all depositors-both in domestic and foreign branches, not just domestic, which they considered discriminatory. They also argued that the government was responsible for guaranteeing at least the minimum deposit insurance amount, because anything else would be a breach of obligation. The position of the Icelandic government was that this was the role of the Icelandic Depositors' and Investors' Guarantee Fund, which had clearly become insolvent with the systematic failure of the Icelandic banking system. The Icelandic government also cited the Emergency Act stipulation that depositors were prioritized in front of other creditors, which increased the likelihood of a full recovery of the deposits. This dispute was settled in the European Free Trade Association's court a few years later; the court dismissed the case of discrimination between domestic and foreign depositors on technical grounds,

29. There had been little preparation for the failure of the banks. Policymakers had prepared a few draft paragraphs for emergency legislation, but little else. The first written document outlining the idea of the split is from September 30, and in it the motivation is said to be "to insure bank service for the general public and firms in Iceland and additionally limit the government's risk from the extensive foreign operations of the banks" (SIC, chap. 20).

30. It took over Landsbanki and Glitnir on October 7, and Kaupping on October 9. 
Figure 27. How the FSA Split the Banks' Balance Sheets into New and Old Banks

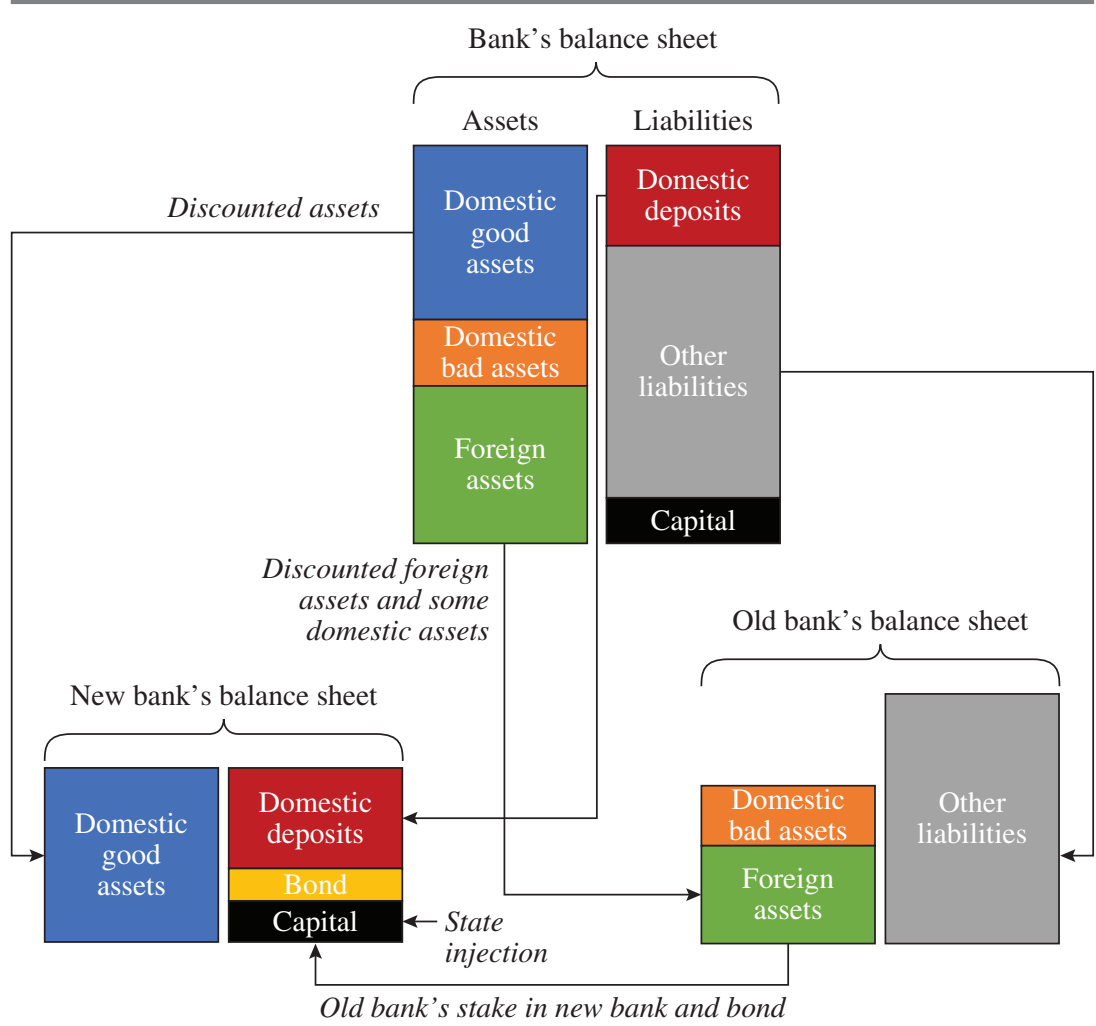

Source: Hafliðason, Valgeirsson, and Marinósson (2009).

and the case concerning breach of obligation was dismissed on the grounds that deposit guarantees are not set up to cope with a systemic banking failure of the scope that occurred in Iceland. ${ }^{31}$

Bank failures are typically considered a very costly affair, and the government has a strong incentive to ex post bail out depositors, and sometimes also other creditors (Chari and Kehoe 2016). The Icelandic government had a strong ex post incentive to bail out deposits in the domestic portion of the banks, and it did so. But the Icelandic government had little incentive to risk taxpayers' money to bail out depositors in foreign branches. ${ }^{32}$ There

31. The European Free Trade Association's ruling can be found at http://www.eftacourt.int/ fileadmin/user_upload/Files/News/2013/16_11_Judgment.pdf.

32. A foreigner with a deposit in a domestic branch was bailed out, and an Icelander with a deposit in a foreign branch was not. 
were high political costs domestically from doing so; much of the political turmoil in Iceland after the crisis came from the strong opposition of Icelandic voters to any law that was seen as bailing out foreign depositors or creditors at taxpayers' expense. Aside from the government's incentive, it is furthermore unlikely that any attempt to bail out the foreign branches would have been credible. ${ }^{33}$

Following the failure of the banks, the króna continued to depreciate. This posed two major problems. First, devaluation fed straight through to foreign currency loans, threatening Icelandic households and firms with no income or assets in foreign currency. Second, the currency depreciation fed into inflation, which then fed into loans tied to the consumer price index, which included almost all mortgages in Iceland at the time. More defaults by households and firms threatened to substantially worsen the ongoing financial crisis. The CBI had few options to support the currency, because its efforts to strengthen foreign currency reserves had already failed earlier that spring, and higher interest rates seemed to do little to stop the outflow.

Capital controls were adopted on November $28,2008 .{ }^{34}$ At that point, the króna had declined about 35 percent in value against the euro in 3 months, and by over 50 percent in 12 months (figure 28). The capital controls were put in place to stem the ongoing capital flight and continuous drop in the value of the currency. Also, the controls provided shelter to different sectors of the economy. The newly established banking sector could retain its important deposit funding without foreign competition. The government got time to regain control over public sector finances and maintained access to domestic funds that were available on good terms because investors were restricted from exiting the economy. And finally, the controls created breathing room for households and firms that had debt in foreign currencies but all their revenues in krónur, whose continuing decline in value threatened to make them insolvent.

The capital controls were implemented in conjunction with the International Monetary Fund's economic program for Iceland, which was also initiated in November. The program included vital financing of $\$ 4.4$ billion,

33. The CBI and the Icelandic government did not have access to foreign financial markets and the CBI's reserves were at that point meager compared to the foreign currency deposits in foreign branches (SIC, chaps. 7, 17, and 20.)

34. The capital controls did allow for purchase of foreign exchange for the imports of goods and service to Iceland. Additionally, as indicated above, any scheduled repayments of foreign loans were permitted. Foreign currency income from exports was subjected to repatriation requirements. The controls put in place broad-based restrictions on investments in any type of foreign asset, such as financial instruments and real estate, and prevented foreign investors who held assets in krónur from recovering their investments (CBI 2012). 
Figure 28. The Euro-Króna Exchange Rate, 2003-17

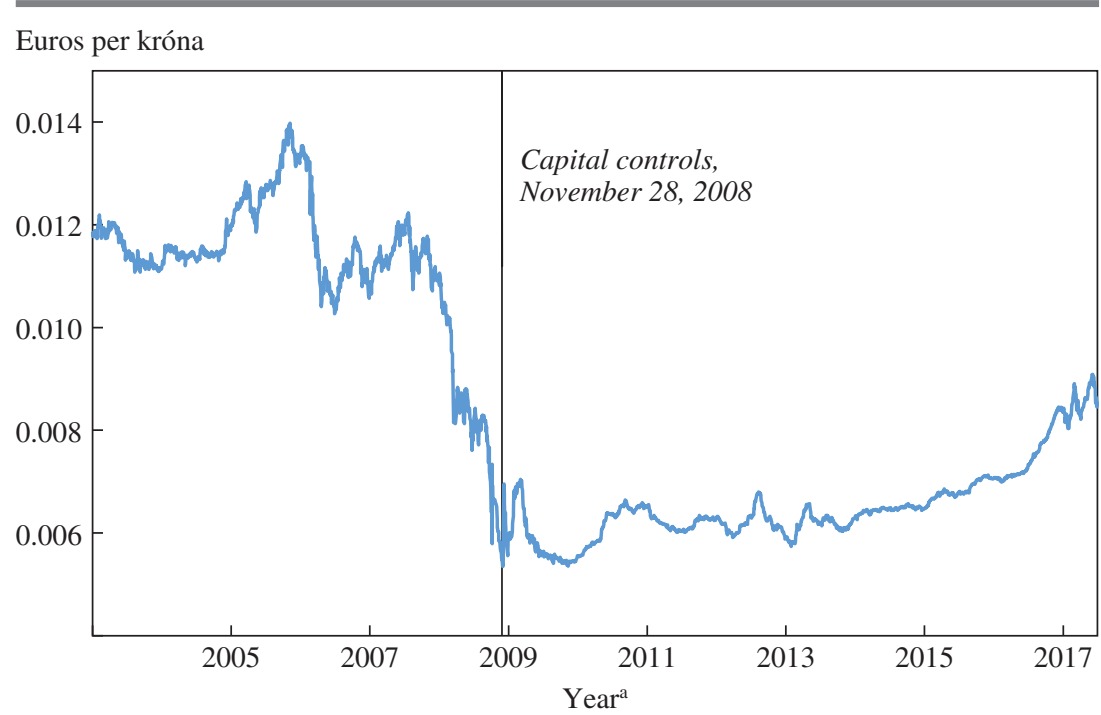

Source: CBI.

a. The data are daily. The ticks mark January 1 of each year.

with $\$ 2.1$ billion coming from the IMF and the rest consisting of bilateral loans from the Nordic countries and Poland (CBI 2010). This financing allowed the CBI to bolster its foreign currency reserves, which was an important first step in the recovery that was sure to take a long time. We discuss the implementation and eventual lift-off of the capital controls in section IX.

\section{Were the Icelandic Banks Solvent?}

It is sometimes said that the model of Diamond and Dybvig (1983) is the bankers' favorite model, because it gives them a reasonable claim for arguing that governments should provide emergency liquidity during a crisis. The model formalizes the notion that even if a bank is "solvent"- that is, the value of the bank's assets exceeds the value of its liabilities-it can still fail if all its depositors demand their money at the same time. This is because banks have long-term assets but short-term liabilities; and their long-term assets, usually in the form of loan contracts, often cannot be sold for their book value in a timely fashion, resulting in fire-sale prices. A bank run can thus be self-fulfilling, because a fully solvent bank can 
become insolvent just because its depositors and other creditors all ask for their money at the same time, forcing the bank to sell its assets prematurely at a discount. The fact that the assets of a failing bank are typically sold at a discount makes it exceedingly hard to assess ex post whether the bank was truly insolvent or was a victim of a self-fulfilling run. With this caveat in mind, it is still interesting to look at the asset recovery rates of the Icelandic banks and to gauge their solvency at the time of their failure.

\section{VI.A. Losses in the Eye of the Storm}

Figure 29 gives a graphic outline of how the assets of the three banks were split up following the crisis. ${ }^{35}$ Collateralized assets were seized immediately by central banks, financial institutions, and other investors that owned secured claims on the banks (the "pledged assets" in figure 29). These assets include loans and securities that had been bundled into assetbacked securities and used as collateral at the ECB and CBI. There is little available information on how large a fraction of the banks' assets was pledged and seized in this way. ${ }^{36}$

In the initial days of the crisis, the Icelandic banks' foreign subsidiaries, which were under foreign supervision, were appropriated by the respective supervisory authorities in various European countries. Some of these subsidiaries were later merged with other financial institutions, while others were liquidated. Toward the end of 2007, these subsidiaries accounted for about 40 percent of the banks' total assets, or more than $€ 45$ billion (CBI 2008a). In the subsidiaries, losses were fully absorbed by equity and subordinated debt, which was fully held by the parent banks in Iceland. However, general senior unsecured debt and deposits were in most cases fully honored. Some subsidiaries issued their own debt instruments, and those rare cases for which we can get some estimation of recovery by respective general claimholders support this. ${ }^{37}$ Once pledged, assets and subsidiaries had been purged from the three banks' balance sheets, each had its own domestic operations, and assets and liabilities were spun off into three

35. The figure was constructed using three different points in time. Because the value of the assets and currencies changed rapidly during this period, there are some discrepancies.

36. One hint of the magnitudes involved was that the SIC estimated that on September 30, collateralized lending amounted to about $€ 5$.2 billion, excluding loans between the Icelandic banks. In some cases, the pledged assets were worth somewhat more than the underlying loan principal due to haircuts, in which case the remainder was paid back to the old banks (SIC, chap. 7, p. 43). The value of pledged assets was falling fast in September.

37. Notable exceptions were the entities in Luxembourg, which were tied more closely to their parent companies; most of their losses in the general liquidation process wound up in the parent companies. 
Figure 29. Assets of Glitnir, Kaupping, and Landsbanki before and after Their Failure

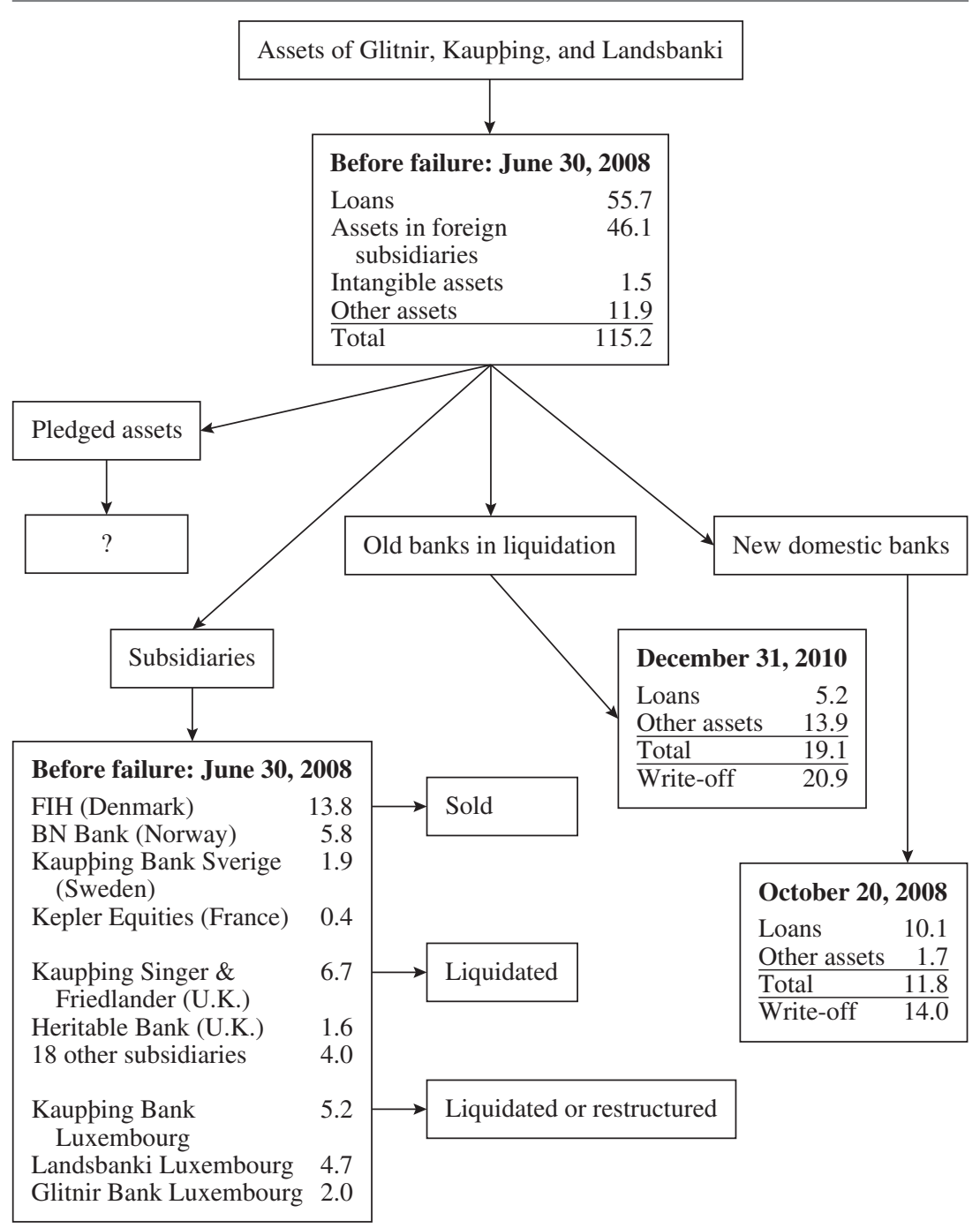

Sources: Annual reports of Glitnir, Kaupping, Landsbanki, Íslandsbanki, Arion banki, and Landsbankinn; financial statements of Glitnir, Kaupping, and Landsbanki; CBI (2008a).

a. The units are billions of euros. 
Table 7. Loan Performance of Glitnir, Kaupping, and Landsbanki as of December 12, 2010

\begin{tabular}{lcccc}
\hline Institution type & $\begin{array}{c}\text { Carrying } \\
\text { value (billions } \\
\text { of euros) }\end{array}$ & $\begin{array}{c}\text { Fair value } \\
\text { (billions of } \\
\text { euros) }\end{array}$ & $\begin{array}{c}\text { Fair value as } \\
\text { a percentage } \\
\text { of carrying } \\
\text { value }\end{array}$ & $\begin{array}{c}\text { Fair value as } \\
\text { a percentage } \\
\text { of total fair } \\
\text { value }\end{array}$ \\
\hline Holding companies & 8.6 & 0.5 & 6 & 10 \\
Other companies & 8.2 & 4.1 & 50 & 78 \\
Financial institutions & 3.3 & 0.6 & 20 & 12 \\
Total & 20.1 & 5.2 & 26 & 100 \\
\hline
\end{tabular}

Sources: Financial statements of Glitnir, Kaupping, and Landsbanki.

separate financial institutions, while the rest was left in a holding company, creating the "new banks" and "old banks," respectively. As explained in section $\mathrm{V}$, the new banks took over domestic deposits, which were fully guaranteed by the government, as well as nearly all domestic loans to firms and individuals. The old banks took over what was left of the banks' assets and liabilities, with the objective of maximizing the assets' value.

The assets of the new banks were estimated at $€ 11.8$ billion at the end of 2008. These assets had a face value of $€ 25.8$ billion, meaning they had been transferred to the new banks at a 60 percent discount. ${ }^{38}$ Similarly, the first complete financial statement of the old banks after their failure, which became available in 2010 , evaluated their assets at $€ 19.1$ billion. The face value of those assets was $€ 40$ billion before the banks' failure, indicating an estimated loan loss of $€ 20.9$ billion, or over 50 percent of the assets' precrisis value. To put these initial assets and write-downs in context, they amounted to $€ 34.9$ billion, or about five times the banks' reported equity before the failure. To the extent that these estimated losses were accuratesomething we revisit just below-the banks were insolvent.

Table 7 reports the estimated loan losses of the old banks at the end of 2010, separated into loans to holding companies, other companies, and financial institutions. In section III, we already discussed loans to holding companies; as the table reveals, these loans were estimated at only 6 percent of face value. As we noted above, parts of the loans to holding companies were extended to purchase shares in the banks themselves, with the only collateral being the shares themselves, in which case the loan was fully lost.

38. It is worth pointing out that it would likely be more difficult to transfer assets and loans with such a large discount in a partial financial system failure due to the implied information about asset values in other, still solvent, financial institutions. Such discounts would likely cause a domino effect of losses on similar or perceived similar institutions. 
Table 8. Estimated Recovery in the Parent Companies as of December 2015, before Payments of the Stability Contribution and Taxes

\begin{tabular}{|c|c|c|c|}
\hline Assets & Billions of euros & Liabilities & Billions of euros \\
\hline $\begin{array}{l}\text { Assets transferred to new banks } \\
\text { against domestic deposits }\end{array}$ & 9.8 & $\begin{array}{l}\text { Domestic } \\
\text { deposits }\end{array}$ & 9.8 \\
\hline $\begin{array}{l}\text { Priority claims paid in the } \\
\text { winding-up proceedings }\end{array}$ & 9.4 & $\begin{array}{l}\text { Paid priority } \\
\text { claims }\end{array}$ & 8.7 \\
\hline Assets in estates & 14.6 & $\begin{array}{l}\text { Accepted general } \\
\text { claims }\end{array}$ & 39.5 \\
\hline $\begin{array}{l}\text { Total } \\
\text { Estimated recovery: } 58 \text { percent. }\end{array}$ & 33.8 & Total & 58.0 \\
\hline
\end{tabular}

Sources: Financial statements of Glitnir, Kaupping, and Landsbanki; annual reports of Íslandsbanki, Arion banki, and Landsbankinn; authors' calculations.

\section{VI.B. Losses through the Cycle at Parent Companies}

The write-offs realized in 2008 and 2010 and reported in figure 29 appear to have been a reasonable approximation for the actual losses as estimated at the end of 2015 in the old and new banks' financial statements. Table 8 summarizes the new and old banks' financial statements for 2015, in which the assets turned out to have appreciated slightly in value. Table 8 is the basis for our recovery estimate, which is 58 percent of accepted claims in the old banks, assuming that both deposits and bonds had the same priority. ${ }^{39}$

Table 9 gives an overview of the latest estimate of ex post recovery rates for types of claims according to their priority. Depositors recovered 100 percent of their claims, both at home and abroad. The recovery rate of general liabilities in foreign subsidiaries were also very close to 100 percent. Recovery of equity and subordinated loans was zero. General creditors of the parent companies-most of which had bought Icelandic bank bonds between 2005 and 2007-also lost a considerable portion of their claims. The eventual write-off for general creditors totaled €28.1 billion,

39. This excludes special bank taxes imposed on the old banks in liquidation and the stability contribution (discussed further in section IX). It is worth noting that this rate only accounts for accepted claims, which were only about half the total claims submitted to the winding-up boards. Some claims were netted out against assets during the winding-up proceedings, some were withdrawn, and others were rejected. The amount paid to accepted priority claimholders is higher than the claim value shown in table 8 , due to exchange rate movements, because claim values are based on the exchange rate on April 22, 2009, per Icelandic law, while payments are based on the spot exchange rate at the time they are made. This result is in line with the findings of Jónsson and Sigurgeirsson (2016), taking into account the special bank taxes, stability contribution, and exchange rate difference between April 22, 2009, and the year-end 2015 spot rate. 
Table 9. Recovery Rate for Liabilities after Stability Contribution and Taxes

\begin{tabular}{lcc}
\hline Assets and liabilities & $\begin{array}{c}\text { Value before } \\
\text { failure } \\
\text { (billions of euros) }\end{array}$ & $\begin{array}{c}\text { Recovery rate } \\
\text { (percent) }\end{array}$ \\
\hline $\begin{array}{l}\text { Deposits from customers in parent company } \\
\text { Deposits from customers in foreign }\end{array}$ & 18.8 & 100 \\
$\quad$ subsidiaries & 14.5 & 100 \\
Asset-backed securities & $>0$ & $29<x<100$ \\
Borrowings and wholesale deposits in & $>52.8$ & 29 \\
$\quad$ parent company & $10<x<20$ & $\approx 100$ \\
$\quad$ Borrowings and wholesale deposits in & & 29 \\
$\quad$ foreign subsidiaries & 8 & 0 \\
Other liabilities & 5 & 0 \\
Subordinated loans & 6.7 & \\
Equity & 115.8 & \\
Total & &
\end{tabular}

Sources: Financial statements of Glitnir, Kaupping, and Landsbanki; authors' calculations.

or approximately twice Iceland's 2007 GDP. ${ }^{40}$ The total equity in the banks before the crisis was $€ 7$ billion, that is, a fourth of the accrued losses. Although there may have been considerable losses due to the assets' firesale prices, as well as a feedback loop between the failure of the banks and the adverse consequences for Icelandic firms, this nonetheless is suggestive of the fact that the Icelandic banks were not solvent at the time of their failure. As such, the Icelandic banking crisis was not an example of a self-fulfilling run, which could have been prevented with a better lender of last resort or alternative funding in foreign currency. Rather, the evidence indicates that the banks were insolvent.

Were the recovery rates poor in the international context? As table 9 reveals, the recovery rate of senior unsecured claims was about 29 percent for general creditors of the Icelandic banks (for example, a typical bank bondholder), which appears low. Although we are not able to do an extensive analysis of recovery across countries and over time, a paper by Viral Acharya, Sreedhar Bharath, and Anand Srinivasan, (2007) offers hints. They compute recovery rates for senior unsecured claims between 1982 and 1999, based on bonds, loans, and other debt instruments. The recovery rates are estimated as 56 percent for all industries and 59 percent for financial institutions. Put in this context, the recovery rate of senior unsecured

40. This figure includes approved claims on the Iclandic banks, after-tax payments, and the stability contribution, and excludes accrued interest for over six years, from the time of the failure until the payments were or will be made. 
creditors was therefore poor in the case of the Icelandic banks. One element that makes this comparison tricky, however, is that all deposits were granted priority in Iceland. In the case of the United States, however, only insured deposits have full priority, while those deposits above the insurance limit become general senior unsecured claims. The numbers are thus not fully comparable, given that there were large, uninsured deposits in the Icelandic banking system that gained priority at the expense of other creditors. $^{41}$

\section{The Output Cost of the Icelandic Banking Crisis}

A major cost associated with a banking crisis is aggregate production forgone. Given the enormous size of the Icelandic financial crisis, the output effects appear relatively modest in the international context, and the recovery seems to have been relatively brisk, at least when taking into account the size of the failed banks relative to Iceland's GDP. Here, we update and extend two well-known metrics of output losses from banking crises-that of Laeven and Valencia (2012), who study 147 crises after 1970; and that of Reinhart and Rogoff (2014), who study 100 crises that span 150 years. The passage of time allows us to update these estimates with longer date series and longer time horizons. The updated assessments suggest that Iceland's output losses, though significant, were not as large as previously thought. We discuss several theoretical possibilities that may help explain the relatively rapid recovery.

\section{VII.A. Extending the Output Loss Metric Proposed by Laeven and Valencia}

Figure 30 shows real GDP normalized to 100 in the year preceding a banking crisis for the 22 advanced industrial economies that are listed in table 10, using the definition of a banking crisis proposed by Laeven and Valencia (2012). Icelandic GDP is depicted by the solid black line. Other countries that are categorized as having experienced a banking crisis in 2008 are shown with solid lines, while dashed lines depict the four other banking crises: Finland in 1991, Norway in 1991, Japan in 1997, and South Korea in 1997. Output fell in Iceland by about 10 percent in the first two years of the crisis; only Greece contracted more during the same period in this sample. If we look toward the end of the period (using the IMF's

41. One can thus think of 29 percent as a lower bound on the recovery rate in the case of the Icelandic banks when compared with the United States but think of 58 as an upper bound. 
Figure 30. The Response of Iceland's GDP to the 2008 Crisis $^{\mathrm{a}}$

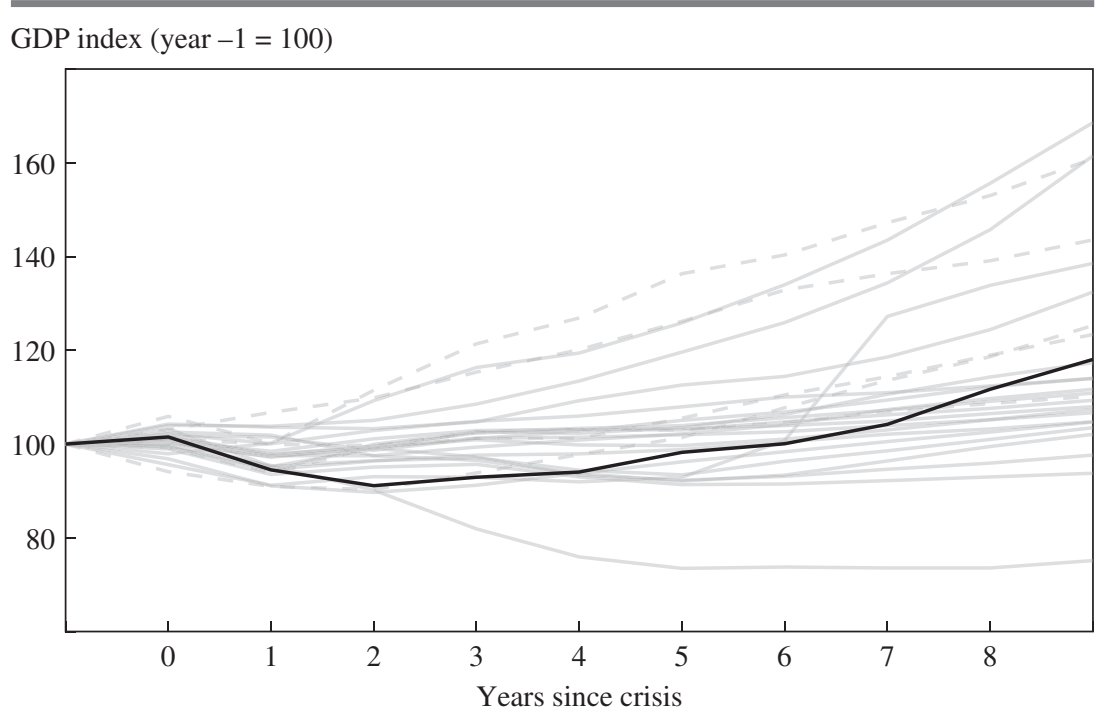

Sources: International Monetary Fund; authors' calculations.

a. The figure shows GDP growth indexed to crisis years for the 22 advanced industrial countries listed in table 10. Iceland is shown as the solid black line, and is indexed to 2008. Finland, Japan, Norway, and South Korea, whose crises occurred in the 1990s, are shown as dashed gray lines. The remaining 17 countries, whose crises occurred in 2007 and 2008, are shown as solid gray lines.

estimate of 2017 GDP), however, Iceland has recovered to beyond precrisis levels, and it has the third-highest level of output of the countries hit by the crisis, relative to 2007.

Laeven and Valencia (2012) estimated the output loss in the three years after the start of a crisis as a fraction of annual production at the start of the crisis. According to their metric, Iceland faced a sizable output loss of 40 percent of GDP, which is comparable to the cost of the Japanese crisis in 1997 and ranks as the 34th-costliest crisis of the 147 crises they consider. It is considerably smaller, however, than many well-known banking crisessuch as those of Argentina in 2001 and Thailand in 1997-where output losses were estimated at about 70 and 100 percent of GDP, respectively.

Figure 31 shows the evolution of Icelandic GDP from 2003 to the IMF's latest estimate of 2017 GDP. The estimated difference between "potential output" and actual output is represented by the first shaded area in the figure. This is scaled to be a fraction of GDP precrisis, that is, in 2008. We now have access to more data, so we also compute the same statistic for six and nine years after the crisis's start, in each case adding the shaded region 
Table 10. Output Loss as a Percentage of GDP over a Period of Years

\begin{tabular}{lcccr} 
Country & Crisis year & $\begin{array}{c}\text { Loss over } \\
\text { 3 years }\end{array}$ & $\begin{array}{c}\text { Loss over } \\
6 \text { years }\end{array}$ & $\begin{array}{r}\text { Loss over } \\
\text { 9 years }\end{array}$ \\
\hline Austria & 2008 & 0.13 & 0.31 & 0.57 \\
Belgium & 2008 & 0.11 & 0.28 & 0.51 \\
Denmark & 2008 & 0.22 & 0.54 & 0.89 \\
Finland & 1991 & 0.48 & 1.02 & 1.44 \\
France & 2008 & 0.15 & 0.37 & 0.67 \\
Germany & 2008 & 0.16 & 0.32 & 0.51 \\
Greece & 2008 & 0.35 & 1.34 & 2.55 \\
Iceland & 2008 & 0.29 & 0.67 & 0.86 \\
Ireland & 2008 & 0.33 & 0.79 & 0.42 \\
Italy & 2008 & 0.26 & 0.75 & 1.40 \\
Japan & 1997 & 0.14 & 0.41 & 0.75 \\
Luxembourg & 2008 & 0.19 & 0.34 & 0.27 \\
Netherlands & 2008 & 0.14 & 0.41 & 0.72 \\
Norway & 1991 & -0.01 & -0.15 & -0.37 \\
Portugal & 2008 & 0.17 & 0.63 & 1.20 \\
Slovenia & 2008 & 0.20 & 0.64 & 1.09 \\
South Korea & 1997 & -0.09 & -0.66 & -1.57 \\
Spain & 2008 & 0.18 & 0.64 & 1.14 \\
Sweden & 2008 & 0.17 & 0.34 & 0.41 \\
Switzerland & 2008 & 0.06 & 0.12 & 0.21 \\
United Kingdom & 2007 & 0.12 & 0.35 & 0.54 \\
United States & 2007 & 0.11 & 0.27 & 0.39 \\
Average & & 0.18 & 0.44 & 0.66 \\
\hline & & & &
\end{tabular}

Sources: International Monetary Fund; authors' calculations.

Figure 31. Iceland's Output Loss over a Period of 3, 6, and 9 Years after the Crisis, 2003-17

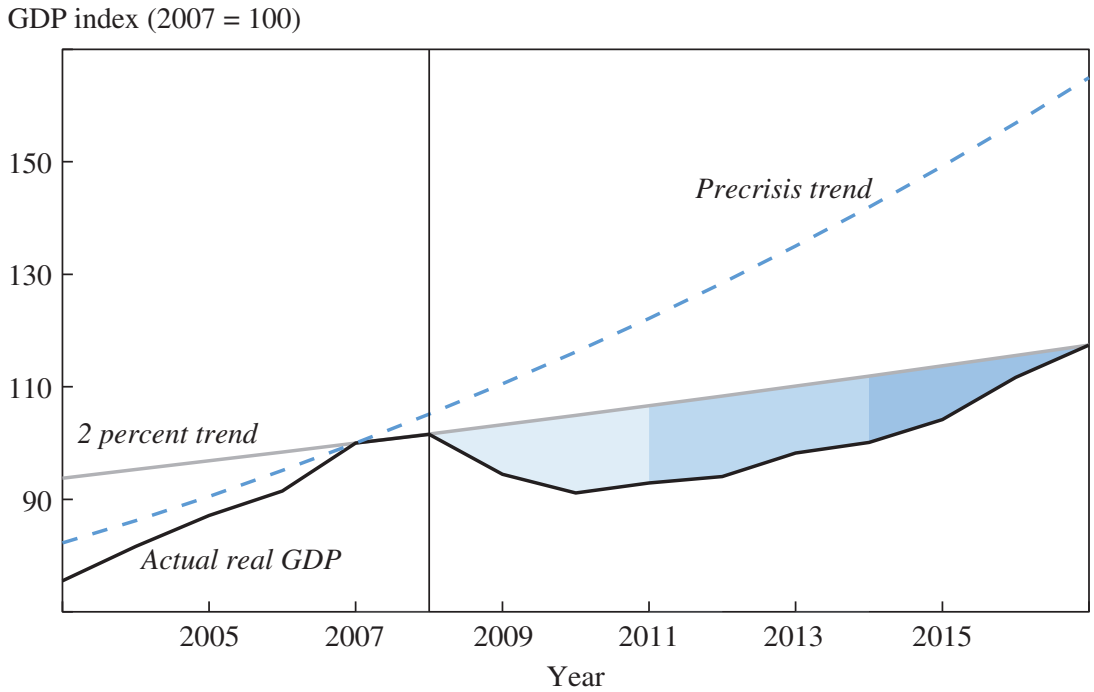

Source: Authors' calculations. 
to the right in the figure. The results are shown in table 10 for a selected number of industrial economies, assuming their potential output is growing at the same rate. Considering a longer horizon reduces the cost of the crisis in Iceland relative to other countries on account of the strength of the recovery. Although the output cost is the fourth-highest according to the three-year horizon, it goes down to eighth place for the six- and nine-year horizons. $^{42}$

As an alternative check on the output cost and the strength of the recovery, we can look at the relative ranking of Icelandic GDP in this period. Iceland was the fourth-richest country in the world in terms of GDP per capita in 2007, and it dropped to 21st place in 2010, according to the International Monetary Fund. It climbs back to fourth place in 2017, the same year that Iceland is assumed to be back at its potential in figure $31 .{ }^{43}$ We will not comment in detail on the other countries in the table, yet it is worth cautioning the reader that there has recently been a debate on the reliability of the GDP data for Ireland, due to its role as a hub for global tax management. ${ }^{44}$

42. Laeven and Valencia (2012) assume that potential output grows at a different pace in different countries. We instead assume that output potential grows by the same amount across all countries (by a constant 1.62 percent per year). Although this makes little difference in the relative ranking of countries at the three-year horizon, it matters more for the six- and nine-year horizons. Though our benchmark has its own problem, we think it gives a more accurate picture of the relative output losses across countries for the six- and nineyear horizons in advanced industrialized economies. The reason is that Laeven and Valencia estimate potential by computing a trend using a Hodrick-Prescott filter for each and every country over 20 years and extrapolate it. The problem is that economic growth is often unsustainable in the time preceding a banking crisis. This is particularly obvious in the case of Iceland, where growth was amplified by large capital inflows, lending growth, and an asset price bubble, giving an estimated potential growth of 5.13 percent per year using Laeven and Valencia's suggested methodology, shown by the steep line in figure 31 . This assumption would clearly exaggerate the estimated output loss for Iceland-especially at the six- and nine-year horizons, even if it matters less at the three-year horizon on which Laeven and Valencia focused.

43. If we instead used the country-specific Hodrick-Prescott trend, the counterfactual growth shown by the line in figure 31 would have made Iceland's GDP per capita the highest in the world today by a wide margin.

44. This debate gathered momentum in 2016, when it was reported that that the Irish economy grew by 26 percent in 2015. Following this, Ireland's Central Statistics Office started presenting "modified gross national income," which it suggested was only 70 percent of GDP, an estimate mostly reached by excluding profits from U.S. companies with considerable operations in Ireland, such as Google and Microsoft. It is beyond our scope to go into the details of this debate, but it is worth noting that we are not aware of any similar possible sources of mismeasurement of Iceland's GDP. For details of the Ireland case, see Boland (2017). 


\section{VII.B. The Output Loss Metric Proposed by Reinhart and Rogoff}

Reinhart and Rogoff (2014) compare the output cost of 100 major banking crises that span 150 years. One advantage of their methodology is that it does not make any assumptions about underlying trends of potential GDP, which we have seen can be important. They construct a severity index for each financial crisis as the sum of the absolute value of the fall in per capita GDP and how long (in years) it takes to get back to the precrisis peak. ${ }^{45}$

We report in table 11 our reestimation of the 11 banking crises in Reinhart and Rogoff's (2014) data set, for which new data exist relative to their paper, and report the difference. Of the cases we reevaluate, the new estimates change most significantly for Iceland and Ireland. Iceland's severity index drops from 23.2 to 18 , resulting in a 14-place drop in its overall ranking of the 100 crises studied by Reinhart and Rogoff. This is below the mean of Reinhart and Rogoff's crisis index, but slightly above the median ${ }^{46}$ The main reason for the change in the assessment for Iceland's GDP in 2017 relative to the earlier assessment is that the current estimate of GDP in 2017 is 15 percent higher than in 2013, while the IMF estimates used by Reinhart and Rogoff predicted it would be only 6 percent higher. ${ }^{47}$ To give perspective on the magnitude of this index, the costliest crisis is that of Chile in 1926, at 62.6, while the value of the index for the Great Depression in the United States is 38.6.

\section{VII.C. A Snapshot of the Icelandic Recovery}

A series of influential papers by Reinhart and Rogoff have made it a stylized fact of macroeconomics that recoveries from a banking crisis are slow. Given the size of the Icelandic banking system once it failed, a reasonable conjecture is that the recovery should have been long and painful. Although the output loss was substantial, we have now presented several measures indicating that the Icelandic banking crisis is quite far from being the costliest such event in economic history in terms of output loss, despite being the largest measured by the size of the banking system relative to GDP.

45. Observe that Reinhart and Rogoff (2014) use real GDP per capita, while Laeven and Valencia (2012) use real GDP; for further discussion, see Reinhart and Rogoff (2014).

46. The aggregate statistics, which we report in the table, are not very different from those reported by Reinhart and Rogoff (2014).

47. Like Reinhart and Rogoff (2014), we rely on the IMF's World Economic Outlook estimate of future output. The new estimation shortens the duration of the crisis by two years. In addition, data revisions make 2008 the precrisis peak rather than 2007, which accounts for one year; and revised data from the IMF put the peak output decline in Iceland at 10 percent, while the data on which Reinhart and Rogoff (2014) relied had it at 12.2 percent. 


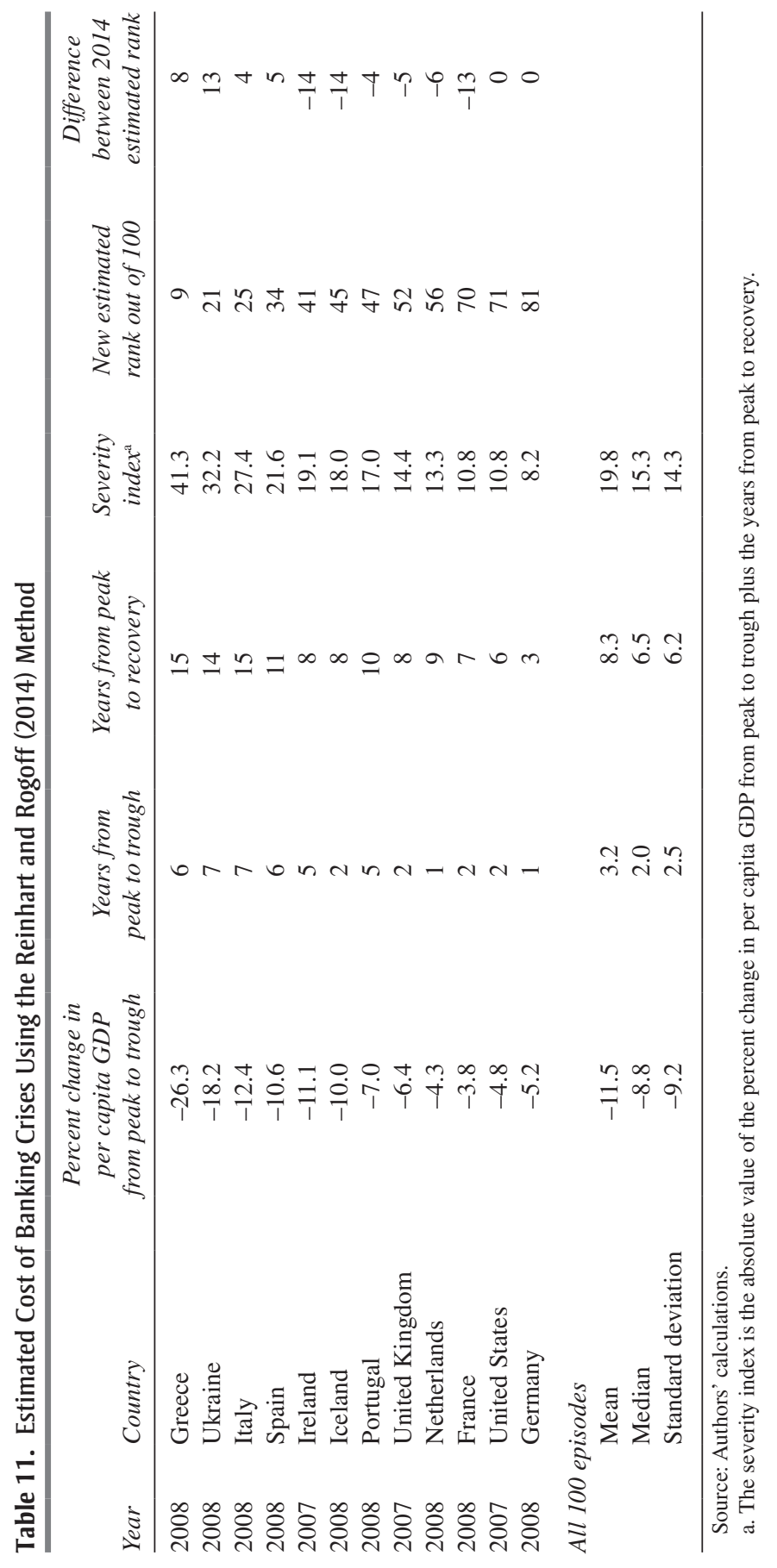


Figure 32. GDP Index at Constant Prices for Iceland and Selected Countries, 2004-17

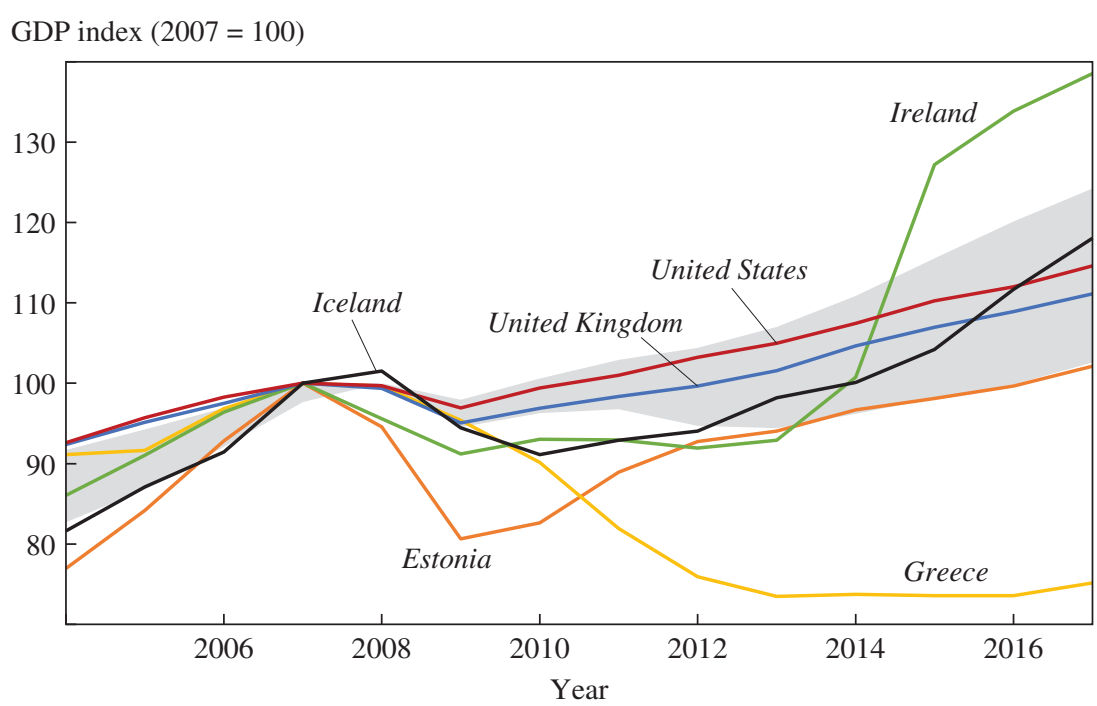

Source: International Monetary Fund.

a. The shaded area denotes the interquartile range of the distribution of indexed GDP for 38 industrialized countries.

The output costs we have documented, when compared across countries and time, may even somewhat overstate the output cost in the case of Iceland, because most advanced economies were also in a recession during Iceland's recovery. South Korea's recovery after the 1997 crisis, for instance, occurred during a time of robust global economic growth. Figure 32 shows GDP in Iceland compared with that in 38 industrialized economies, normalized to 100 in 2007, from which we have extracted a few special cases. The shaded area represents the interquartile range of the distribution. Laeven and Valencia's (2012) data set identifies 20 of these 38 countries as having gone through a banking crisis in this period. As of 2017, the index for Icelandic GDP is above the U.S. index and above the sample median. The evolution of employed workers, as shown in figure 33, shows an even stronger Icelandic recovery. Here, we offer a possible explanation for the strength of the recovery, relating it to the literature on the possible output cost of a financial crisis. We leave a detailed, model-based analysis to future work.

One common explanation for the slowness of the recovery of countries from banking crises is the presence of "zombie firms" on banks' balance sheets, which keep lending to insolvent firms to avoid necessary write-offs in their loan books, in which case banks may not satisfy capital adequacy 
Figure 33. Employment Index for Iceland and Selected Countries, 2004-17

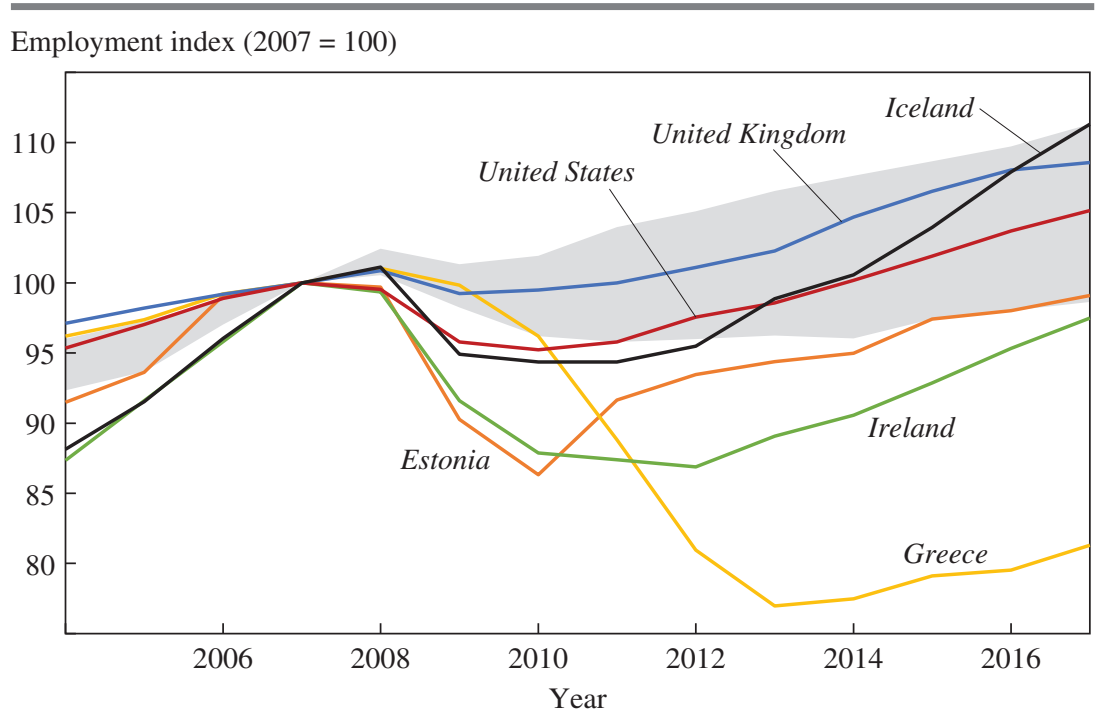

Source: International Monetary Fund.

a. The shaded area denotes the interquartile range of the distribution of indexed employment for 38 industrialized countries.

regulations (Caballero, Hoshi, and Kashyap 2008). This leads to capital misallocation, as the zombie firms starve new and more promising firms from securing funding. We saw some evidence of this type of behavior in the lead-up to the financial crisis in Iceland, when some borrowers became "too big to fail" and were likely funded beyond what was optimal (see section IV). However, the incentives for the banks changed after the establishment of the new banks. Loans to Icelandic firms and households were transferred to the new banks at a 60 percent discount of the claim value, on average, and equity was injected into the new banks. In contrast to the Japanese banks analyzed by Ricardo Caballero, Takeo Hoshi, and Anil Kashyap (2008), the new Icelandic banks had the scope and incentives to restructure corporate and household debt, and little incentive to keep zombie firms afloat.

Figure 34 shows that the actual default ratios of corporations and households in Iceland were significantly higher in 2009 and 2010 relative to many industrialized economies at that time. However, these ratios fall off fast after that, suggesting that the new banks were more aggressive in going through debt restructuring. Because the reported ratios represent defaults from the newly reevaluated loan books in Iceland, the solid black line in the 
Figure 34. Default Ratios for Corporations and Households in Iceland and Selected Countries, 2007-16

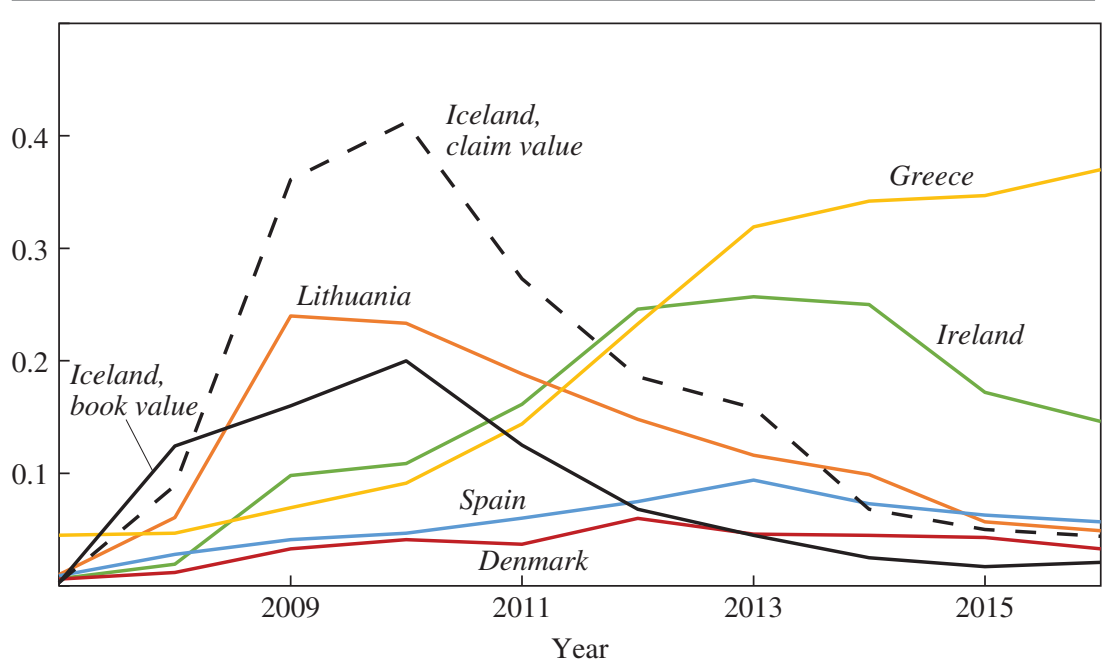

Source: CBI (2017b).

figure is an underestimate of loans in default, while the dashed line, which shows the actual default on the precrisis book value of the loans, is an overestimate. ${ }^{48}$ Nonperforming loans rose from being less than 1 percent to over 40 percent of the initial claim value of the loans. The new banks supported the firms they assumed were viable, while other firms were wound up at a relatively high frequency in the initial years. Figure 35 shows that reorganization was successful in more than tripling firms' equity ratios, from about 12 percent in 2008 to over 40 percent in 2015.

A second popular explanation, closely connected to the first, is that the crisis itself is triggered by agents accumulating "too much debt" and the recovery is slow because of forced deleveraging-following what is often referred to as a "Minsky moment" (Eggertsson and Krugman 2012; Mian, Rao, and Sufi 2013; Guerrieri and Lorenzoni 2017). As those overextended agents are forced to pay down their debt, there is a slowdown in spending and someone else must pick up the slack. The shorter the deleveraging

48. To the extent that other countries did not reevaluate their loan books in a similar manner, the dashed line is more comparable to what we report in other coutries. But it is beyond our scope here to make a similar correction for the comparison countries, because this is likely to have differed from country to country. 
Figure 35. Icelandic Firms' Equity Ratio, 2002-15

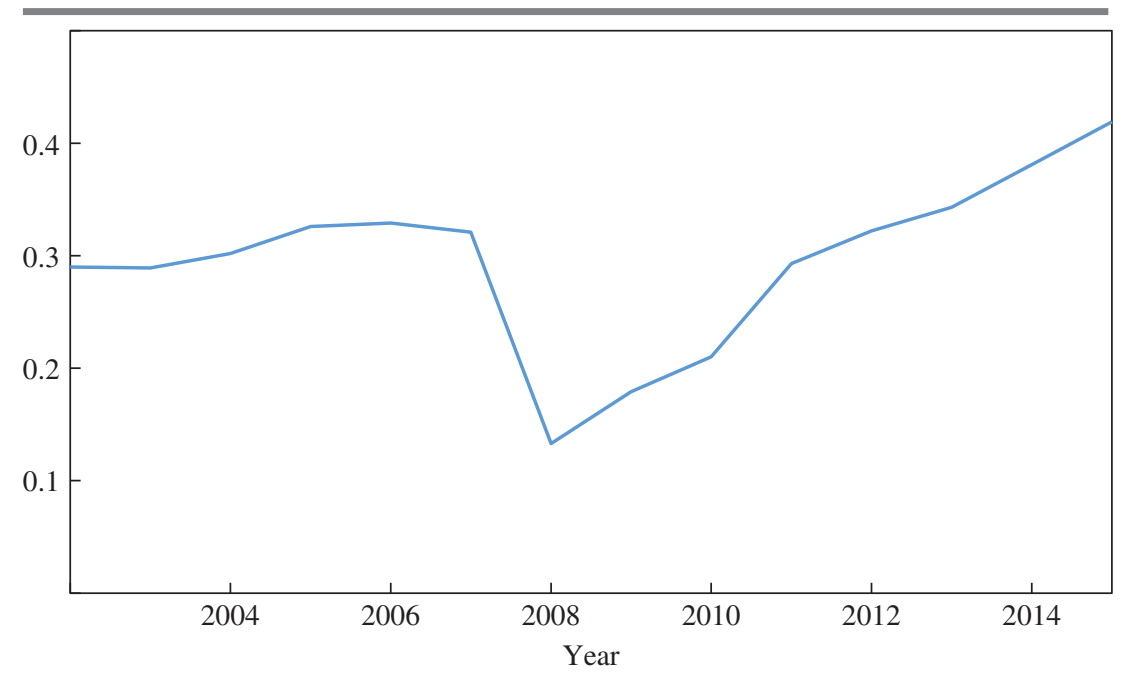

Source: CBI (2017b).

process, the stronger the recovery will be (Benigno, Eggertsson, and Romei 2014). Figures 36 and 37 show household and firm debt as a percentage of GDP, illustrating the sharp decline in debt following the crisis in comparison with a selected number of countries. A significant part of this sharp decline was the aggressive debt restructuring, made possible by the initial asset write-off when the new banks were founded. Another important factor was specific government policies, including household debt writedowns and giving individuals access to pension savings to pay down loan principals. Moreover, the Supreme Court determined that the loan contracts linked to foreign currency offered by the banks before the crisis were illegal, which markedly reduced the value of outstanding debt (CBI 2012) ${ }^{49}$

The central banks' ability to cut interest rates is a key element emphasized by Gauti Eggertsson and Krugman (2012) and Veronica Guerrieri and Guido Lorenzoni (2017) to speed up debt deleveraging, and thus speed up recovery from a financial crisis. A key constraint identified in this literature is the problem of the zero lower bound on interest rates, which became a

49. For households, about 60 percent of the debt deleveraging was due to illegal loans linked to foreign currency, about 20 percent was due to policy put in place soon after the crisis, and another 20 precent was due to the so-called indexed loans principal reduction policy (Forsætisráðuneytið 2013). Firms' debt reductions were more due to write-offs, restructurings, and loan paybacks. 
Figure 36. Household Debt for Iceland and Selected Countries, 2003-16

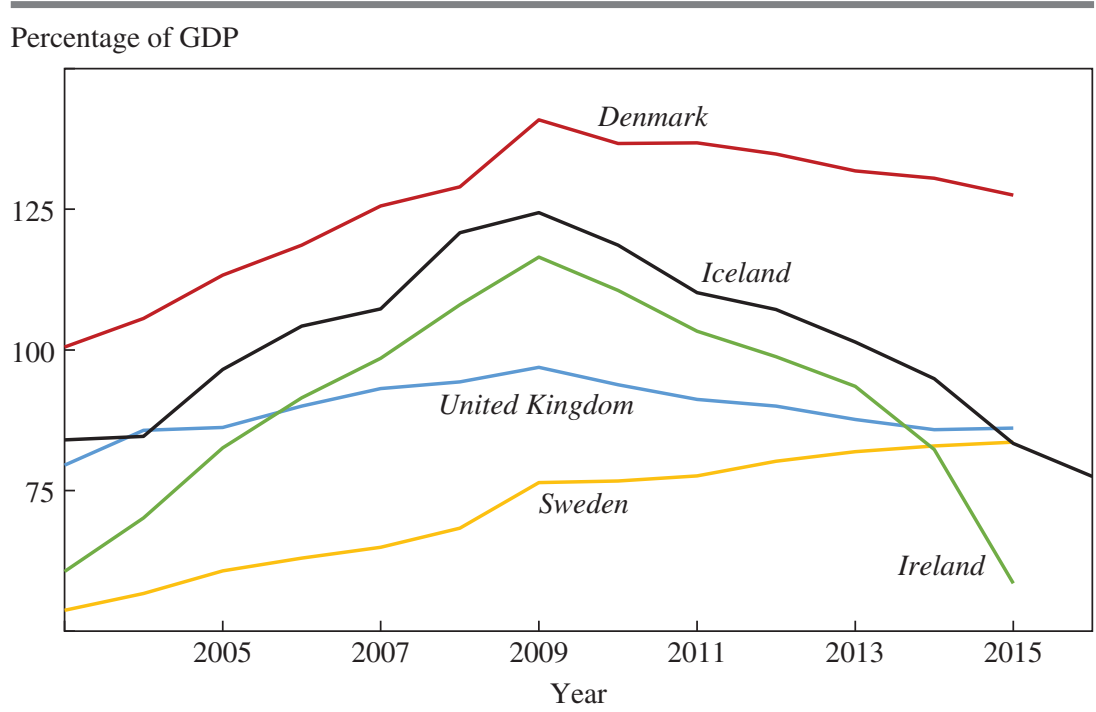

Source: CBI (2017b).

Figure 37. Corporate Debt for Iceland and Selected Countries, 1995-2016

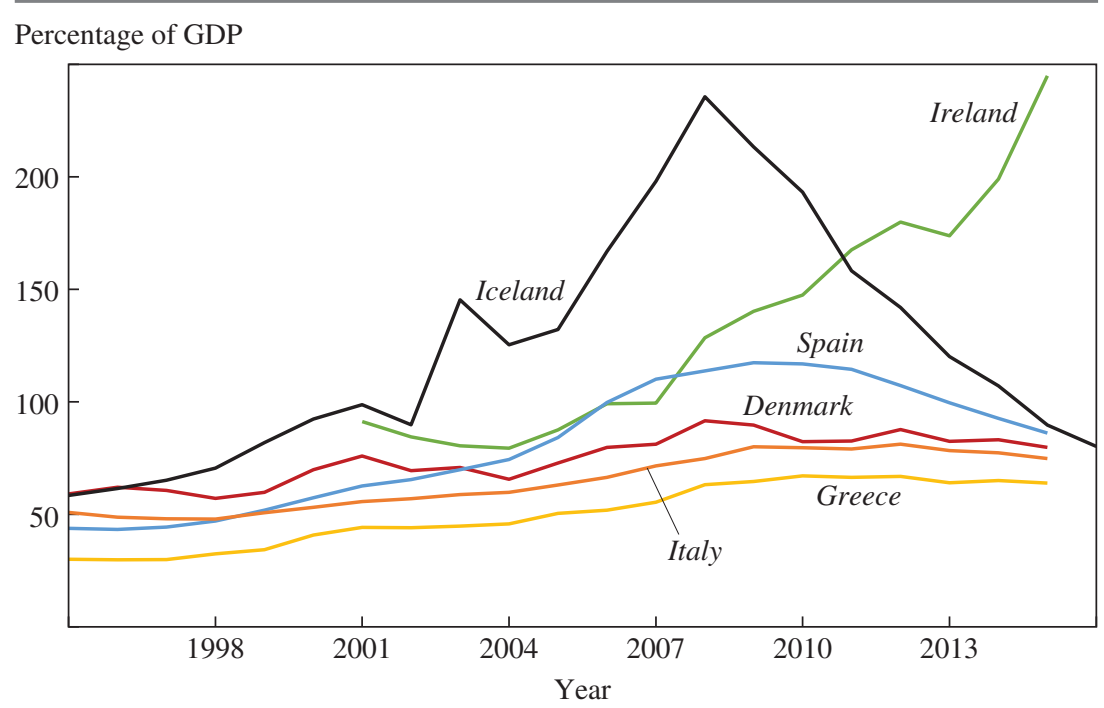

Source: CBI (2017b). 
major constraint for the ECB, Bank of Japan, and Federal Reserve during the crisis. The CBI, however, never faced the zero lower bound, partially due to higher inflation during the downturn driven by the large currency devaluation at the time of the crisis (which is discussed in greater detail in section IX). The Icelandic króna depreciated against the value of the euro by about 50 percent over the 12 -month period before capital controls were implemented in fall 2008. The combination of capital controls and the large devaluation may thus have contributed to easier monetary conditions than other countries were able to provide-because they were either constrained by the zero lower bound or were part of a larger currency area and thus could not flexibly devalue their currency. It also insulated the Icelandic government from the sovereign debt crisis that shook Europe in 2012. Iceland's freedom to devalue the króna during the crisis, to the extent it helped the recovery, lends some credence to the provocative claim by Krugman (1991) that Iceland was an optimal currency area, an idea we do not try to formally evaluate.

One hint of the importance of devaluation in the recovery is the large reversal of the current account shown in figure $38 .^{50}$ The current account surplus has been on average 6 percent of GDP since 2008. The reversal of the trade balance was driven by a sharp turnaround in the terms of trade and a decline in domestic demand for, in particular, foreign investment goods and foreign consumption goods. The financial account also improved markedly as interest expenses declined by 14 percent of GDP from 2008 to 2009 due to delinquent failed bank debt. Adding to the reversal in the trade balance has been a massive explosion in tourism. The tourism boom was partially triggered by the large initial devaluation, but a well-coordinated effort by the government and firms starting in 2010 to attract tourists could also have played a role. ${ }^{51}$ Applying a wider definition of tourism (including airline transportation), tourism now makes up about 40 percent of Iceland's total exports (figure 39).

There is also evidence of external debt deleveraging. Although the presence of the large Icelandic banks greatly complicated computation of Iceland's net international investment position, especially right before

50. The current account balance for Iceland shown in figure 38 is the so-called underlying current account, which excludes the effect of the failed banks in winding-up proceedings starting in 2008:Q4.

51. For example, in 2010, a collection of firms together with the government and local authorities launched an advertising campaign called "Inspired by Iceland" (Arena, Bhattachaya, and Böwer 2017). Google searches for Iceland also peaked in April 2010, after the Eyjafjallajökull eruption. 
Figure 38. Current Account Balance for Iceland and Selected Countries, 2004-17

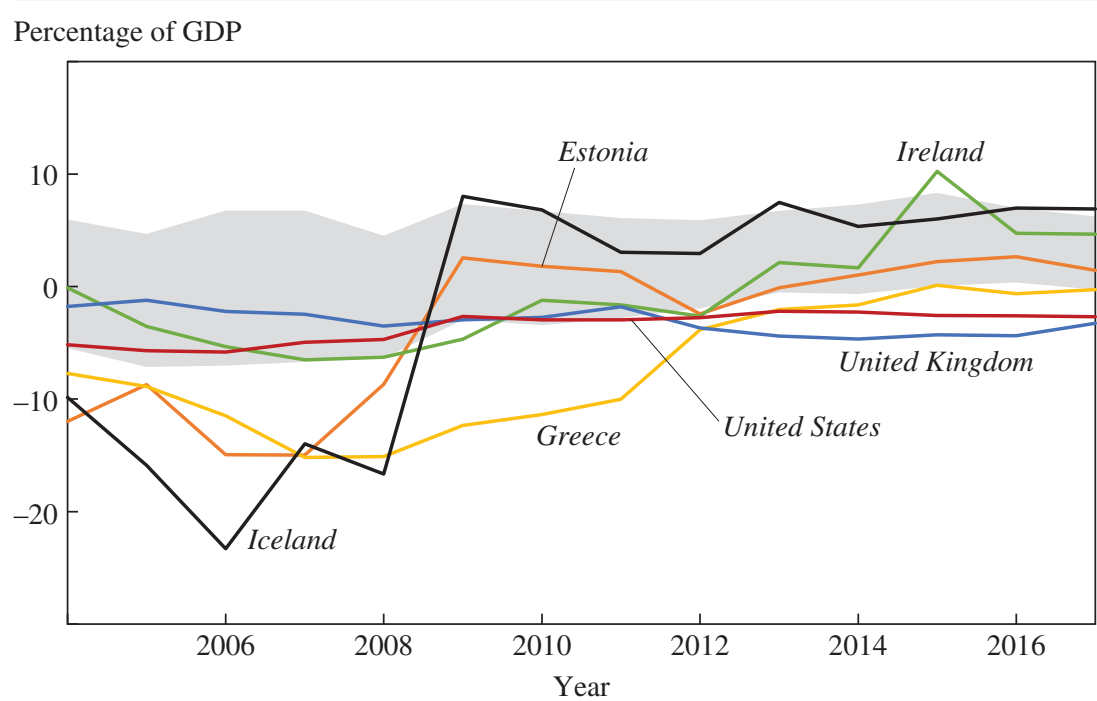

Sources: International Monetary Fund; CBI (2017b).

a. The shaded area denotes the interquartile range of the distribution of current account balances as a percentage of GDP for 38 industrialized countries.

Figure 39. Iceland's Exports of Goods and Services, 2003-16

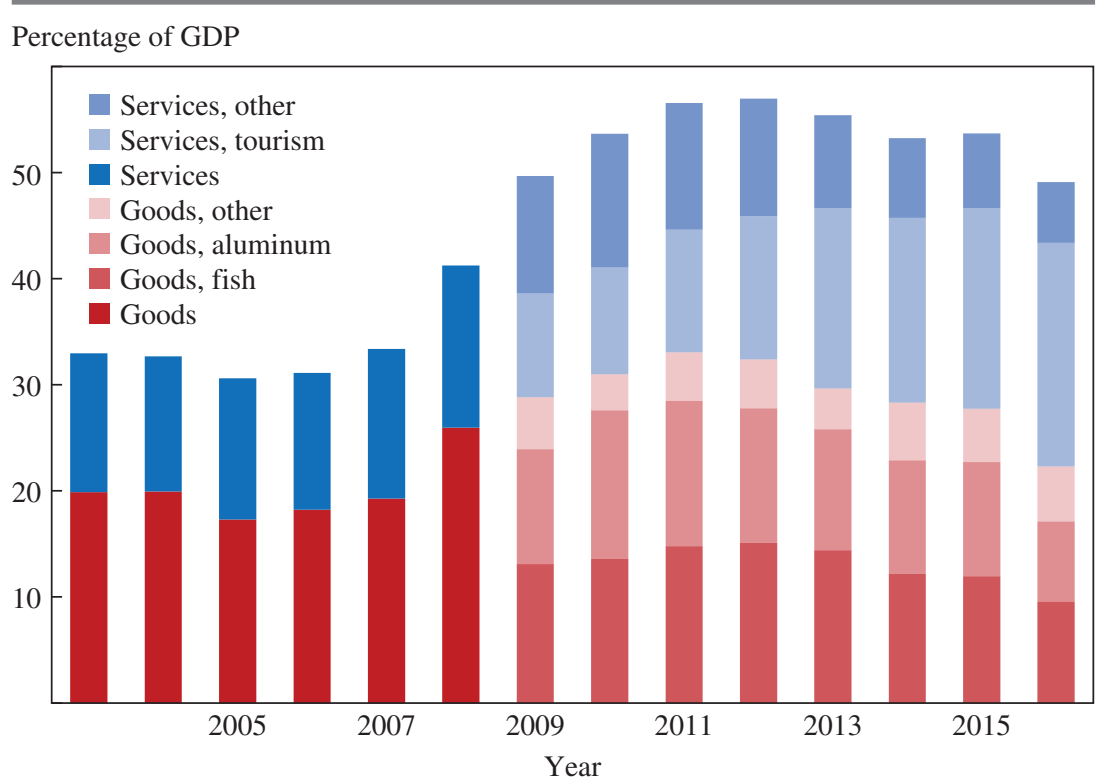

Source: Statistics Iceland. 
Figure 40. Iceland's Net International Investment Position, 1995-2016

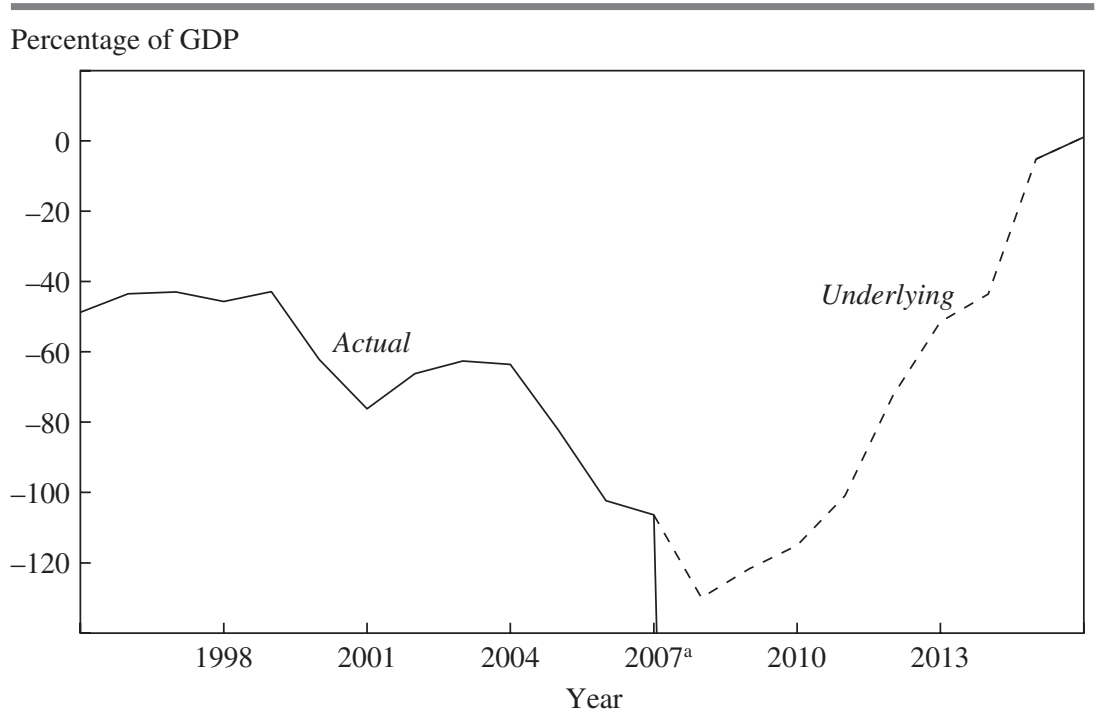

Source: CBI (2017b).

a. Between 2007 and 2008, the actual net international investment position dropped to -663.5 percent of GDP.

and around the time of the banks' failure, there is reason to believe that the CBI's computation of this statistic gives a reasonable estimate of the underlying net international investment position; see the dashed portion of the line in figure 40. Since the failure of the banks, the net international investment position of the Icelandic economy has changed dramatically, and now stands at 1 percent of GDP. The rapid improvement of the external positions since 2008 is mainly due to three factors. First, the external debt of failed firms has been written down by foreign creditors. Second, the current account surplus has made it possible for other firms and entities to pay down their foreign debt quite rapidly. Third, the stability contribution of the old bank estates alone improved Iceland's external position by about 20 percent of GDP. We document this key element of the recovery in the next two sections.

\section{The Fiscal Cost}

The Icelandic banking crisis is sometimes cited as one of the costliest on record from the perspective of government finances. This is based on two measures relative to GDP: gross fiscal outlays, and the net increase in 
Figure 41. The Gross Fiscal Cost of Banking Crises for Iceland and Selected Countries

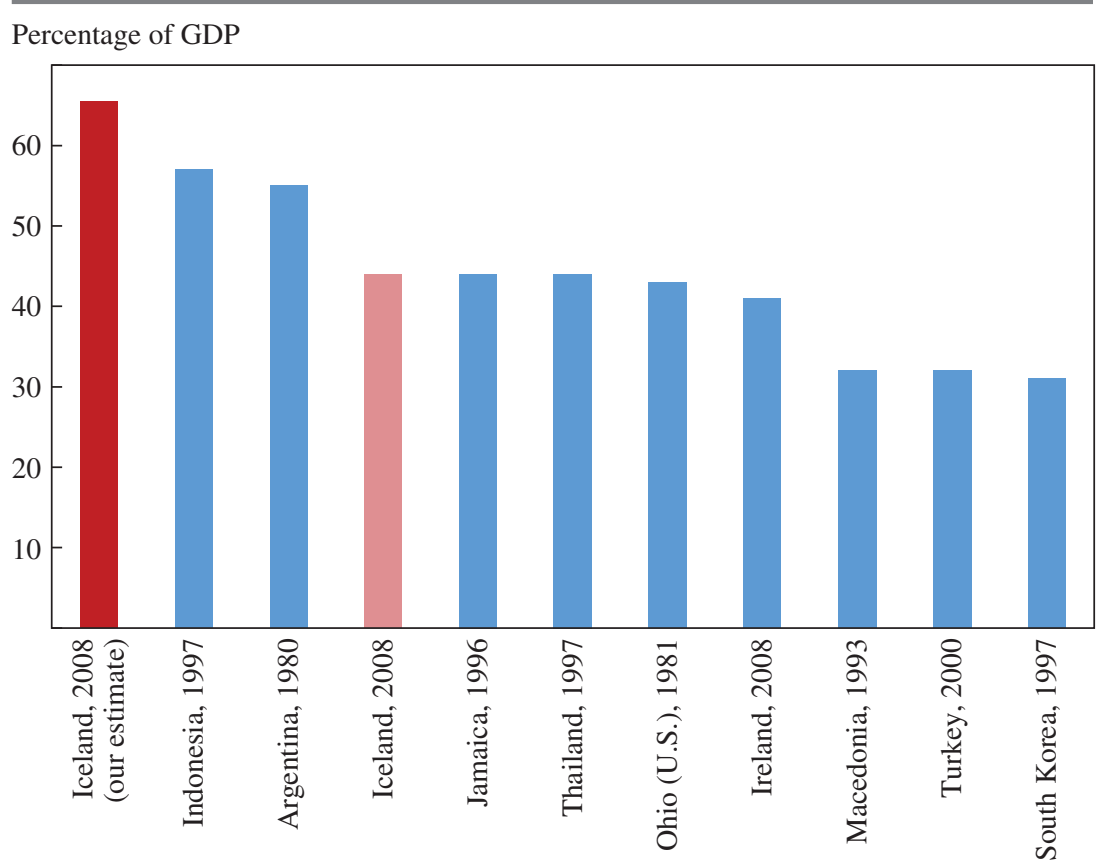

Country, year of the crisis

Sources: Laeven and Valencia (2012); authors' calculations.

a. Except where noted, all estimates are from Laeven and Valencia (2012).

public debt. Measured by gross fiscal cost, Iceland's banking crisis was the third-costliest of the 147 crises in Laeven and Valencia's (2012) sample, while it was the seventh-costliest measured by the increase in government debt (figures 41 and 42, respectively, excluding the columns labeled "our estimate," which is discussed below).

Here we present new evidence on the fiscal cost of the Icelandic crisis. According to our calculations, the fiscal cost is notably lower than estimated in 2012. There are also scenarios, which do not look too unreasonable, under which the Icelandic government's net cost is negligible or even turns into revenues. It should be emphasized, however, that this estimate is still subject to uncertainty, given that it depends significantly on the market value of the government's stake in the new domestic banks.

There are two main reasons why the outlook for the fiscal cost is now much better than in 2012. First, the outcome shown in figure 41 is gross cost, which does not net out the value of the assets the government acquired 
Figure 42. The Increase in Debt from Banking Crises for Iceland and Selected Countries

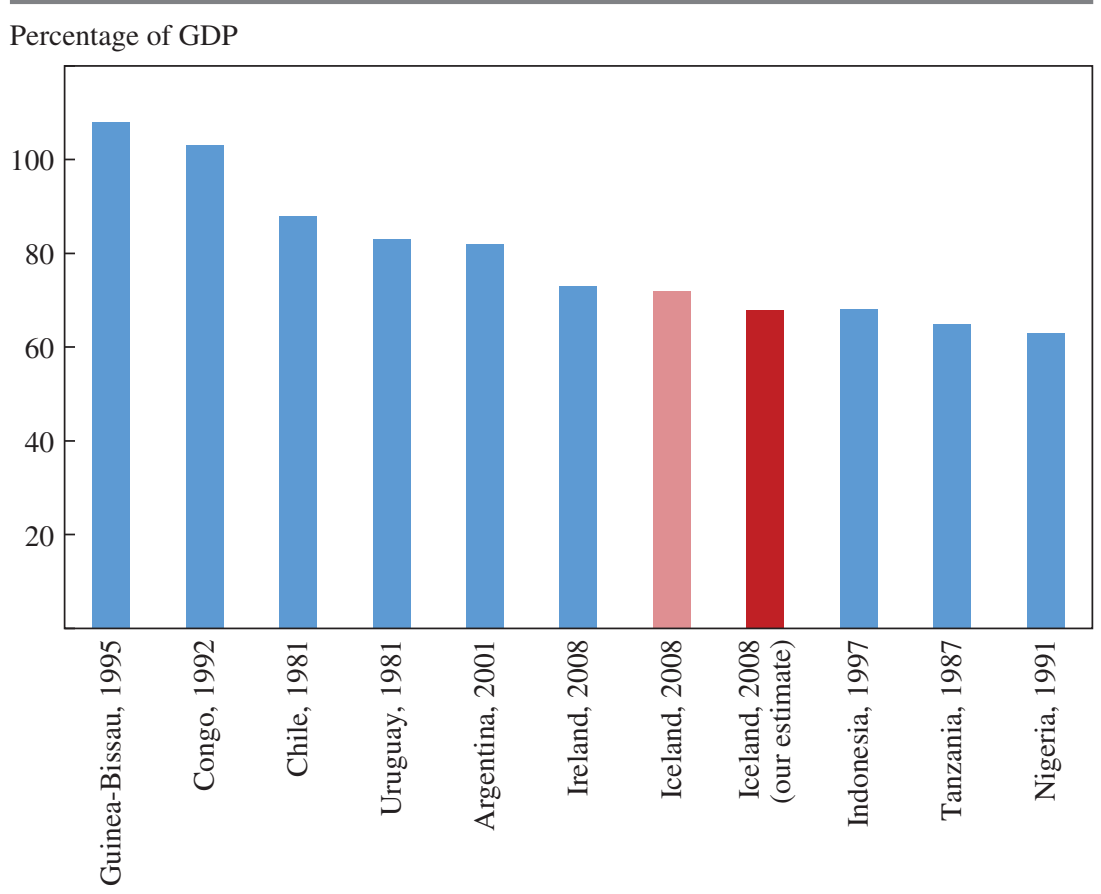

Country, year of the crisis

Sources: Laeven and Valencia (2012); authors' calculations.

a. Except where noted, all estimates are from Laeven and Valencia (2012).

concurrently. Laeven and Valencia (2012, p. 6) choose to "focus on gross fiscal costs instead of net because the gross amount reflects the intensity of the intervention." The precrisis size of the Icelandic banking sector alone implies a very intense intervention; but as we will see, a significant portion of this intervention is likely to be recovered. The second reason is the stability contribution, amounting to 18 percent of GDP and paid by creditors of the failed banks to fulfill so-called stability conditions in exchange for exemption from the capital controls for the estates (see section IX).

Table 12 shows the gross and net costs of the crisis by dividing the nominal cost in each year by the nominal GDP of that year, the same methodology as used in the IMF's (2012) assessment.

The largest outlay is attributed to the CBI Holding Company, amounting to -53.5 percent of GDP gross cost, or -17.2 percent of GDP net. This 


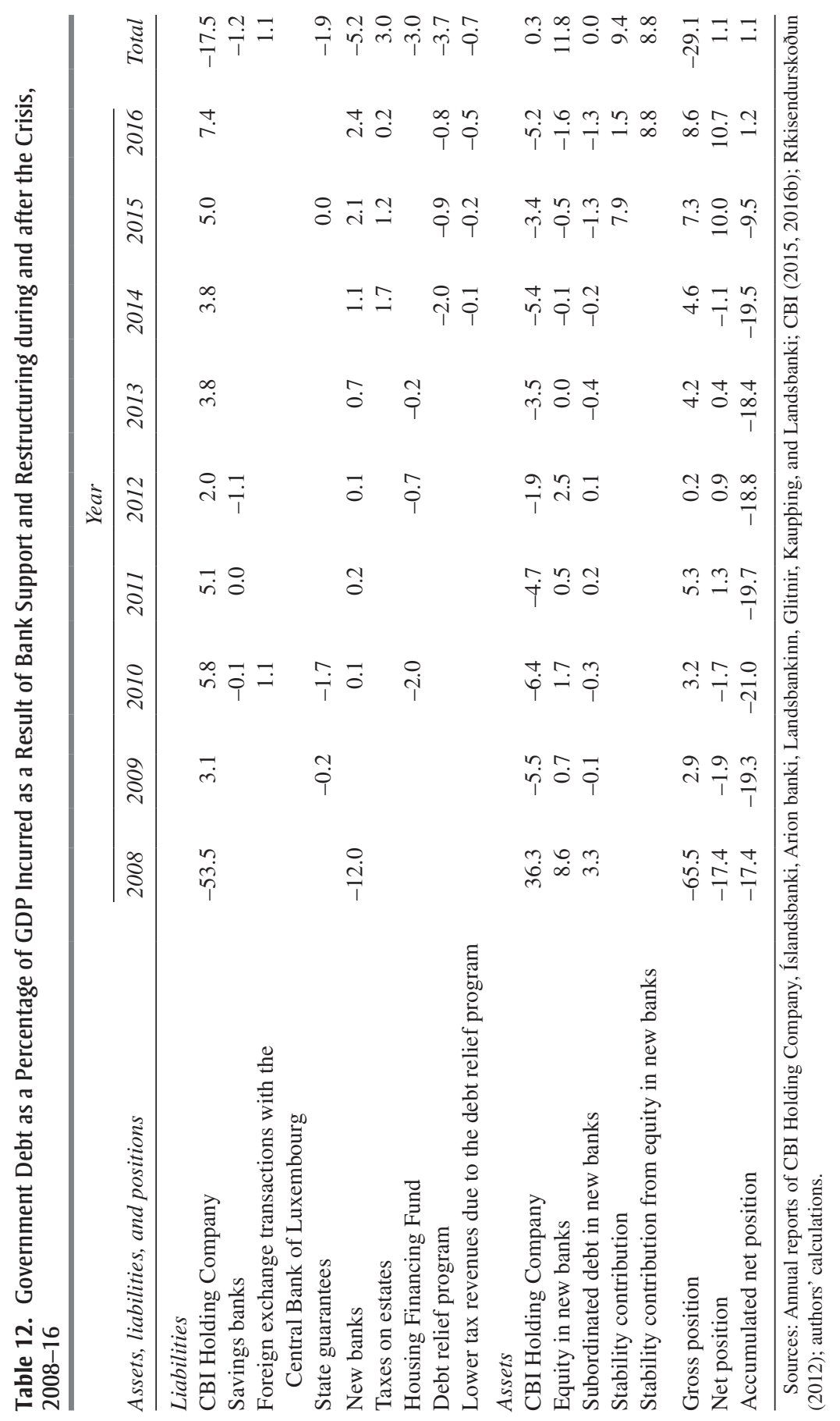


company was established to unwind assets that the CBI and the Treasury took over during the crisis. ${ }^{52}$ Most of the assets were repossessed by the CBI on account of its collateralized lending to the failed banks - the love letter trade we discussed in some detail in section II. The write-offs due to the love letter claims were estimated at 17.2 percent of GDP in 2008 and an additional 1.4 percent of GDP in 2009, although the eventual write-offs due to collateralized lending by the CBI ended up closer to 14.5 percent of GDP. This is the largest portion of the net fiscal cost of the crisis. Additional write-downs of other assets were also necessary, most notably the one of about 2.5 percent of GDP on the Danish bank FIH. A subsidiary of Kaupping, FIH was accepted as collateral on an emergency liquidity funding loan of $€ 0.5$ billion extended to Kaupping two days before the bank's failure. The CBI only recovered about half the emergency loan when FIH was sold in 2010, resulting in a loss of about 2.5 percent of GDP. The CBI Holding Company also further wrote down some claims against savings banks, an insurance company, and other smaller assets. In 2016, most remaining CBI Holding Company assets were sold, so there is good reason to believe that the current estimate is close to being accurate.

The second-largest cost is the state's refinancing of the new domestic banking system, with a gross cost of 12 percent of GDP in 2008. The refinancing was in the form of equity injection and subordinated loans. Since 2008 , the recovery of these assets-in the form of dividends, interest payments, and installments-has been 6.8 percent of GDP. The net cost still outstanding is 5.2 percent of GDP. Additionally, the government's stake in the new banks, based on the crisis equity injection, has a book value of 11.8 percent of GDP. The market value of the equity is uncertain, however, and is discussed in more detail just below.

Other government expenses that were incurred in connection with the crisis were much smaller. Outlays due to smaller savings banks are included in the CBI Holding Company line in table 12. The recapitalization of the Housing Financing Fund was necessary to offset losses on mortgages. Finally, there is the net fiscal gain in 2010 due to a transaction between the Central Bank of Luxembourg and the CBI. The Central Bank of Luxembourg

52. The CBI Holding Company was formally established in late 2009, with a balance sheet book value of 490.6 billion krónur. The claim value was 289.1 billion krónur higher, which is the amount of the initial write-offs. In 2009, the CBI and the Treasury recovered 72.1 billion krónur in assets from collateralized lending. This was added to the initial opening balance sheet of the CBI Holding Company. This method involved a slight overestimation of the gross position because a small portion of the assets on the CBI Holding Company's opening balance sheet were claims that came about in 2009 , after the failure of a few smaller banks. 
was at this time the largest holder of the offshore króna position (for more details, see section IX), which was wound down in this transaction. ${ }^{53}$

The aftermath of the crisis involved more fiscal revenues that countered the initial outlays. The single most important was the so-called stability contribution from the creditors of the failed banks, amounting to 18.2 percent of GDP (see section IX). Half the stability contribution was directly or indirectly connected to ownership stakes in two of the new banks, which resulted in the state now owning over 99 percent of Íslandsbanki (formerly Glitnir), and the dividends and sales proceeds of Arion banki (formerly Kaupping) were split between the state and claimholders. ${ }^{54}$ This added an estimated 8.8 percent of GDP in the state's ownership of banks, which resulted in it owning what amounted to 20.6 percent of GDP in bank equity at book value at the end of 2016. Other postcrisis revenues include a tax on the estates of the failed banks amounting to 3 percent of GDP.

The fiscal cost of the Icelandic crisis critically depends on the assumed market value of the new banks. In table 12, we appraise them at book value. This resulted in an accumulated fiscal gain of 1.1 percent of GDP at the end of 2016. This estimation is subject to uncertainty, however. ${ }^{55}$

The actual sale price of the new banks relative to their current book value affects the fiscal gain or losses through two channels. First, it affects them directly through the shares the government holds, shown in the row labeled "equity in new banks" in table 12. Second, it affects the stability contribution, shown in the last row of assets in table 12. If the banks are sold at a 10 percent discount from book value, this results in an increase in fiscal cost amounting to over 2 percent of GDP. Figure 43 and table 13 show the sensitivity of our estimate to different values of the price-to-book ratio, as of the end of 2016. A price-to-book ratio ranging from 0.25 to 1.25 gives a fiscal gain or loss of between -14.8 and 7.2 percent of GDP. ${ }^{56}$

53. This relates to lending from the ECB and the collateral that one Icelandic bank posted before its failure, in part to replace the love letters that the ECB had rejected. In 2010, the CBI took over this collateral and paid the ECB the nominal amount owed in full. Yet because the ECB had applied significant haircuts to the collateral, the CBI was able to resell these assets to Icelandic pension funds 12 days later at a profit. The price reflected a 25 percent discount from the listed price, but this trade resulted in a profit corresponding to 1.1 percent of GDP at that time.

54. The state already held a 99 percent stake in Landsbankinn (formerly Landsbanki).

55. The government injected about 12 percent of GDP into the banks, and it has recouped about 6.8 percent of GDP in repayments of subordinated debt and dividend payments, leaving 5.2 percent of GDP. The current book value of the government's stake in the banks is 11.8 percent.

56. The CBI (2015) used a slightly more conservative range of 0.5 to 1 for the price-tobook ratio. 
Figure 43. The Net Fiscal Cost of the Icelandic Crisis at the End of 2016

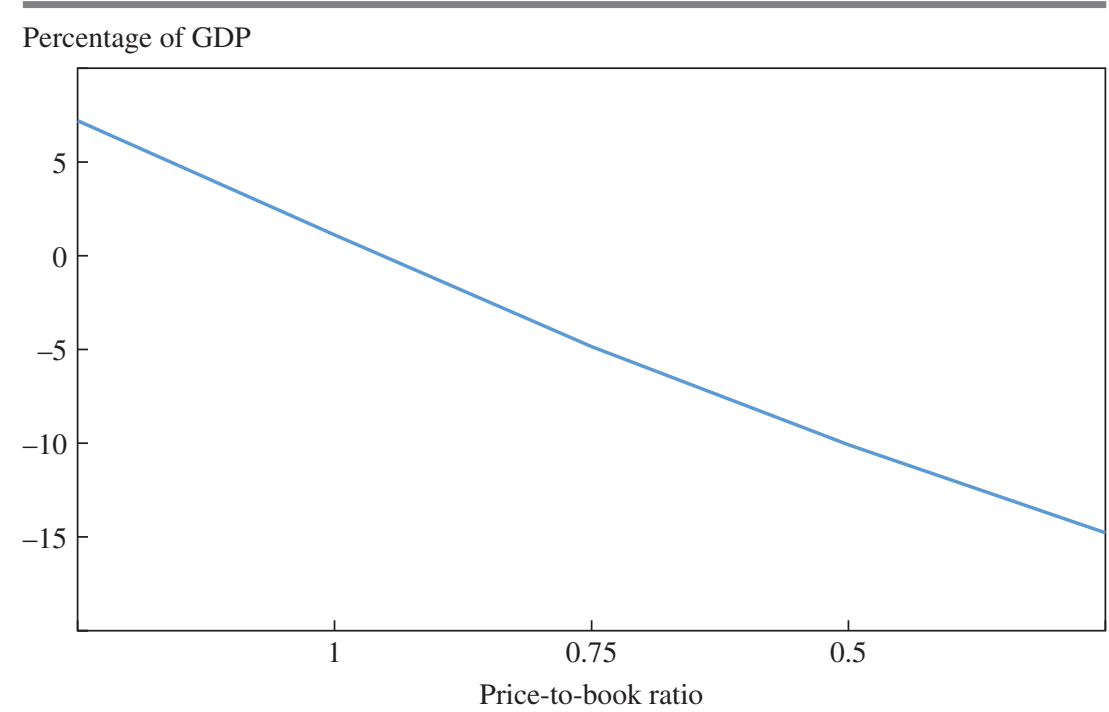

Source: Authors' calculations.

Our conservative baseline scenario is a price-to-book ratio of 0.75 , which results in an accumulated fiscal loss of 4.9 percent of GDP. There are a number of reasons we choose this relatively conservative baseline. First, in February 2017, a 30 percent stake in Arion bank was sold in a private placement at a price-to-book ratio of close to 0.8 (Arion banki 2017). Other things could also affect the price of the banks, including relatively high capital requirements and a heavy tax burden compared with banks in other countries. The banks also operate in one of the smallest currency areas in the world, and hence they have limited growth opportunities. Rules and regulations put in place following the crisis, based on the understanding that there is no lender of last resort in foreign currency, further limit

Table 13. Net Position of Fiscal Cost based on the Price-to-Book Ratio for the Government's Share in the New Banks

\begin{tabular}{lccccc}
\hline & \multicolumn{5}{c}{ Price-to-book ratio } \\
\cline { 2 - 6 } Net position & 1.25 & 1 & 0.75 & 0.5 & 0.25 \\
\hline Billions of krónur & 127 & -20 & -165 & -291 & -405 \\
Percentage of 2016 GDP & 5.3 & -0.8 & -6.8 & -12.0 & -16.7
\end{tabular}

Sources: Annual reports of Íslandsbanki, Arion banki, and Landsbankinn; CBI (2016b); authors' calculations. 
international growth. We therefore assume that a conservative price for the Icelandic banks is more likely.

The fiscal costs amassed in the aftermath of the crisis are limited to the debt relief program for households. This program involved direct write-downs of inflation-indexed household mortgage loans and tax relief on private pension fund withdrawals used to pay down mortgage loans. The direct government expenses to compensate financial institutions for loan write-downs was 3.7 percent of GDP, and income tax losses from 2014 to 2019 are estimated at 0.7 percent of GDP (assuming a 30 percent income tax on an average pension).

In the last line of table 12, we report the accumulated net loss, evaluating at book value both the equity of the new banks and the assets of the CBI Holding Company. In 2010, the accumulated net loss of the banking crisis peaked at 21.0 percent of GDP, and it was 19.7 percent at the end of 2011, according to our estimate. This is slightly higher than the estimated fiscal cost reported by the IMF (2012) in April 2012, which was 19.2 percent, and slightly lower than the 23.7 percent cost estimated by Laeven and Valencia (2012). ${ }^{57}$

In 2012, Laeven and Valencia estimated gross fiscal outlays of 44 percent of GDP and a net increase in public debt of 72 percent of GDP. Our estimate in table 12 is that the gross fiscal outlay amounted to 65.5 percent of GDP, which means that the Icelandic crisis is the most expensive crisis in gross terms in Laeven and Valencia's data set (figure 41). The net increase in public debt was 67.7 percent of GDP from 2007 to the peak in 2011. This moves Iceland's ranking one place back in the comparison of net increases in public debt, from the seventh to eighth place (figure 42). It is important that this measure of fiscal cost only looks at the increase in debt four years after the crisis. Significant costs have been recouped since then, which, coupled with the robust recovery of GDP, puts government debt as a percentage of GDP at 45.5 percent, down 50 percentage points from its peak and only 18.1 percentage points above the precrisis level. ${ }^{58}$

For robustness, we also use a method suggested by the Congressional Budget Office (2016) for estimating the cost of the U.S. Treasury's Troubled Asset Relief Fund. It involves computing the payment and income streams connected to the crisis, with appropriate discount rates. Using this

57. It is worth noting that at the start of the crisis, when Iceland entered a standby agreement with the IMF, the cost was estimated at -40 percent of GDP (IMF 2012).

58. Another example of a large difference between gross and net fiscal costs was seen in the Swedish banking crisis, where the gross fiscal outlay was 3.6 percent of GDP (Laeven and Valencia 2012), while the net fiscal loss was 2 percent or less (Englund 1999; Ingves and Lind 1997). 
Figure 44. The Icelandic Government's Debt, 1998-2017

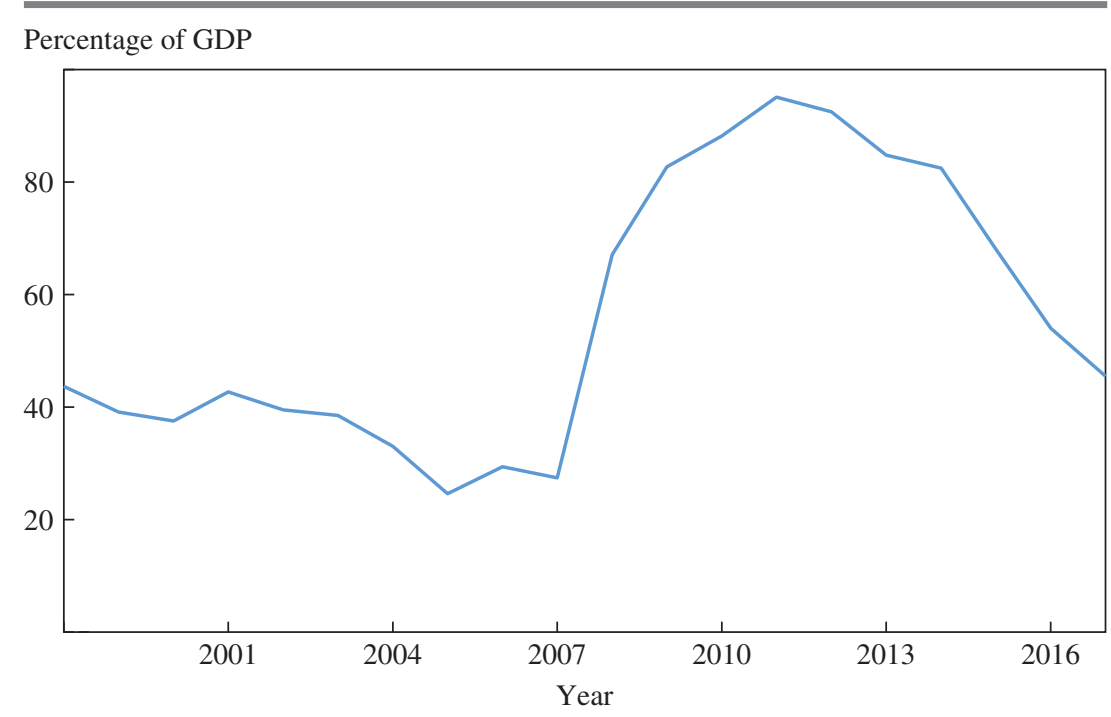

Source: Statistics Iceland.

method, and with the five-year government bond rate in Iceland as the discount rate, our estimated fiscal cost of the crisis is 0.8 percent of 2016 GDP, when we use the book value of the equity in the new banks (see table 13). Using our baseline price-to-book ratio of 0.75 , the fiscal cost of the crisis is 6.8 percent of 2016 GDP. Table 13 shows the sensitivity in these calculations with respect to the price-to-book ratio, ranging from a 16.7 percent of 2016 GDP fiscal loss to a 5.3 percent of 2016 GDP fiscal gain for priceto-book ratios between 0.25 and 1.25 . This is almost identical to the result using the IMF methodology.

These estimates of the fiscal cost do not take into account a few items. One is possible gains or losses from the settlement of the stock of offshore krónur. This settlement was closely linked to the buildup of foreign currency reserves at the CBI following the crisis, which was also costly. This estimation also does not account for potential output losses and the degree to which they could affect the government's budget. There was a substantial loss in tax revenues, and there were also increases in crisis-related costs, such as unemployment benefits. As shown in figure 44, public debt is currently about 18 percent of GDP-higher than it was before the crisis in 2008 - and much of this can be accounted for by the drop in government revenues in the aftermath of the crisis. 


\section{The Role of Capital Controls and the Balance of Payments}

As explained in section $\mathrm{V}$, capital controls were adopted in Iceland on November 28, 2008, and they remained in place until the winter of 2016-17, when they were gradually lifted. The loosening of the controls followed the fulfillment of stability conditions by foreign creditors of the old bank estates. In 2008 the capital controls, in conjunction with an IMF program, stabilized the currency within a few months, fulfilling their main objectives.

The capital controls restricted capital movement and placed repatriation restrictions on foreign currency export revenues. They were quite effective in achieving the former, in part due to the simplicity and low connectivity of Iceland to the international financial system. In the first months following the banks' failure, and the subsequent closure of their payment lines, the CBI served as the intermediary in all payments to and from Iceland (CBI 2008b). ${ }^{59}$ This simplified the supervision of the capital controls greatly. Connectivity increased over the period, but only modestly and only through the largest banks, which were well supervised.

Repatriation of export revenues was, however, not satisfactory until all ambiguity concerning the prohibition on unilateral importation of offshore krónur was removed in October 2009. ${ }^{60}$ The effectiveness of these capital controls may be difficult to replicate in larger, more complex, and highly connective economies (Guðmundsson 2012). In these first years of the capital controls, the króna was trading on the offshore market with at least a 20 percent discount, suggesting outflow pressures that the controls were aimed at containing. ${ }^{61}$

Why were the capital controls kept in place for so long? A key reason was that to lift them would mean risking capital flight, leading to a balance of payments crisis, currency depreciation, and a potential risk to financial stability. The main source for these concerns was the old banks in liquidation. It may seem surprising that private banks that failed posed a significant risk to financial stability years after their failure. But considering the details of why this assessment was made provides an interesting case study of a possible balance of payments crisis and the application of capital controls, relating quite closely to the economic literature on this topic,

59. Today there are still only seven lines connecting Iceland to the international financial system, through the CBI, four commercial banks, and two payment solution firms.

60. Before that, exporters sold their foreign currency for krónur offshore to investors, mostly carry traders, who owned krónur (CBI 2012).

61. "Offshore market" refers to trade between nonresidents abroad. 
Figure 45. Foreign/Domestic Breakdown of Assets and Claims of the Old Banks at the End of 2014

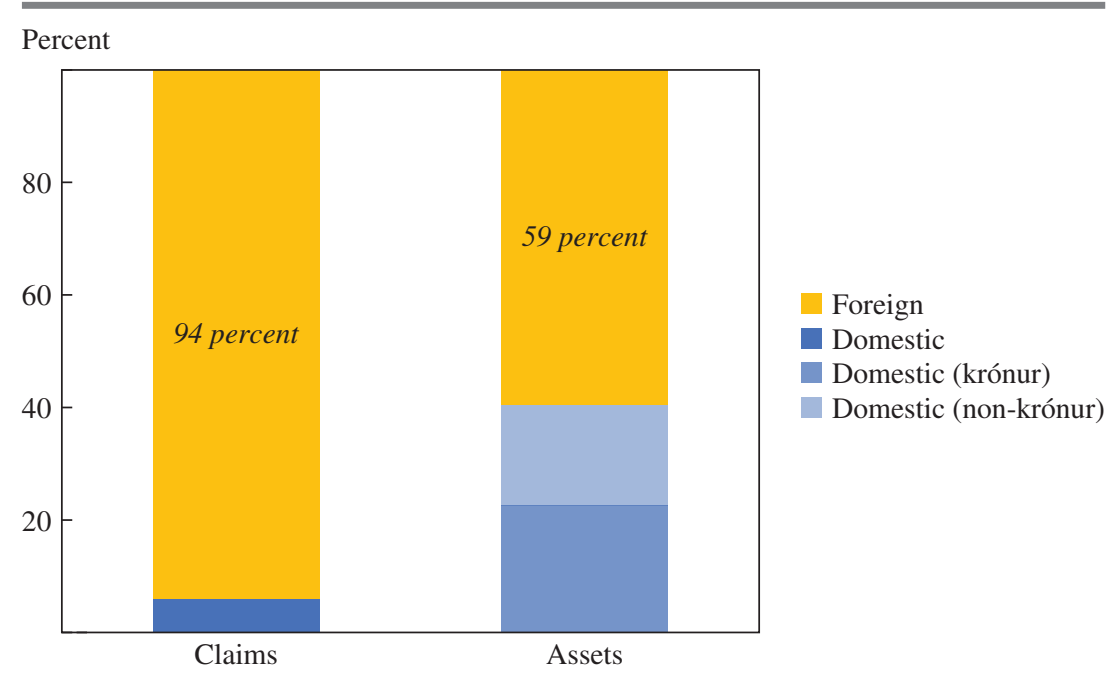

Source: CBI (2015).

such as Calvo (1998), Krugman (1999), Reinhart and Reinhart (2008), and Caballero (2016), all of which highlight problems with sharp reversals of capital flows.

To better explain this problem, it is useful to look at the sources of possible capital flight. It mainly had three sources. First, at the end of 2015, the total remaining assets of the estates of the three large banks amounted to well over 100 percent of Icelandic GDP. The problem is that only 6 percent of the claims on the estates were from domestic creditors, while 41 percent of the assets of the estates were domestic (see figure 45). This meant that many domestic assets, mostly denominated in krónur, would be liquidated, converted into foreign currency, and distributed to foreign creditors. It was estimated in 2015 that this settlement of the failed banks' estates would have a negative effect on Iceland's strained international investment position, amounting to nearly 18 percent of GDP. ${ }^{62}$ Additionally, there were deep concerns about the effect on the already fragile domestic currency.

62. This estimate, based on the position in 2015:Q3, is the difference between the value of domestic assets that would have reverted to foreign creditors and foreign assets that would have reverted to domestic creditors, taking into account that some of the domestic assets were already collateralized or prefunded with underlying foreign assets (CBI 2016a). 
Figure 46. Offshore Króna-Denominated Assets, 2009:Q1-2016:Q2

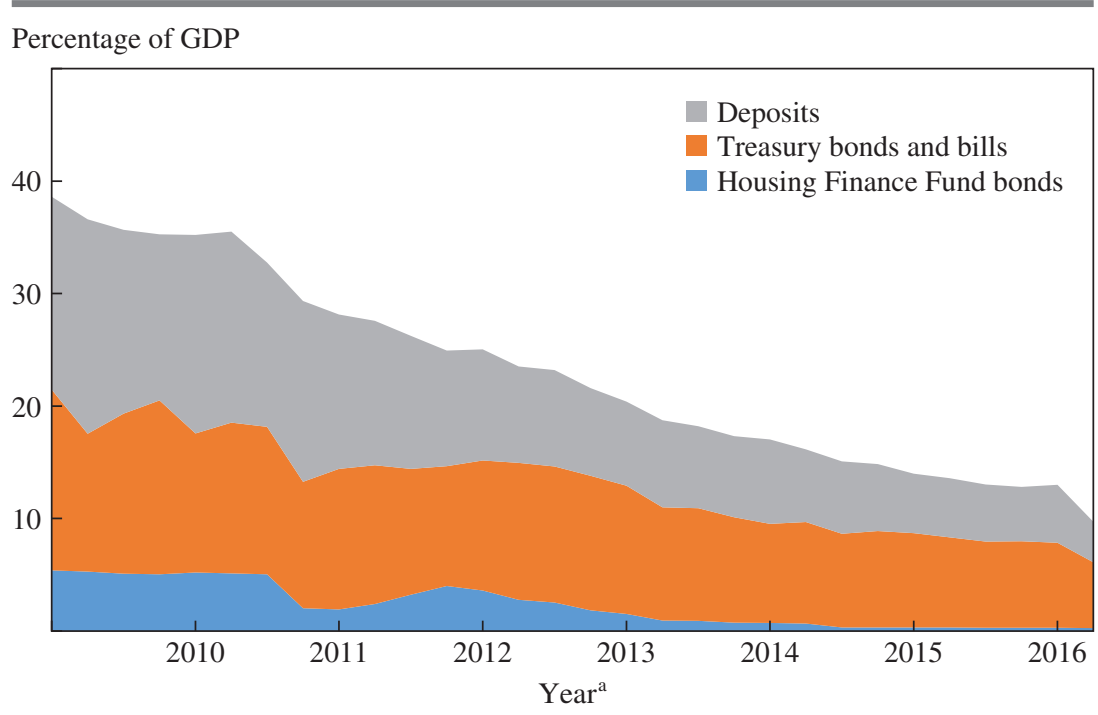

Source: CBI (2016a).

a. The data are quarterly. The ticks mark quarter 1 of each year.

The second source of outflow pressure was liquid króna-denominated assets in the hands of nonresidents (see figure 46). This was largely the remnant of the precrisis carry trades. It was in the form of króna deposits and government bonds amounting to about 35 percent of GDP at the beginning of 2009. The stock of liquid króna-denominated assets held by nonresidents declined to about 14 percent of GDP between 2009 and 2015, as a result of the CBI's foreign currency auctions and other direct transactions. This still implied a threat to the balance of payments at the end of 2015, amounting to 14 percent of GDP, or double the current account surplus at the time.

The third source of capital outflow concern was domestic firms, individuals, and, in particular, pension funds that following the onset of the crisis sought to maintain their assets in foreign currency due to a lack of confidence in the domestic currency.

The combined potential negative balance of payments effects from the first two sources were estimated to be about 32 percent of GDP at the end of 2015 (the sum of the two bars in figure 47). The risk of domestic investment flight from Iceland was, however, always heavily reliant on whether the solutions to the former two problems instilled confidence in the currency and on general economic conditions. Concurrent with these outflow 
Figure 47. The Balance of Payments Problem at the End of 2015

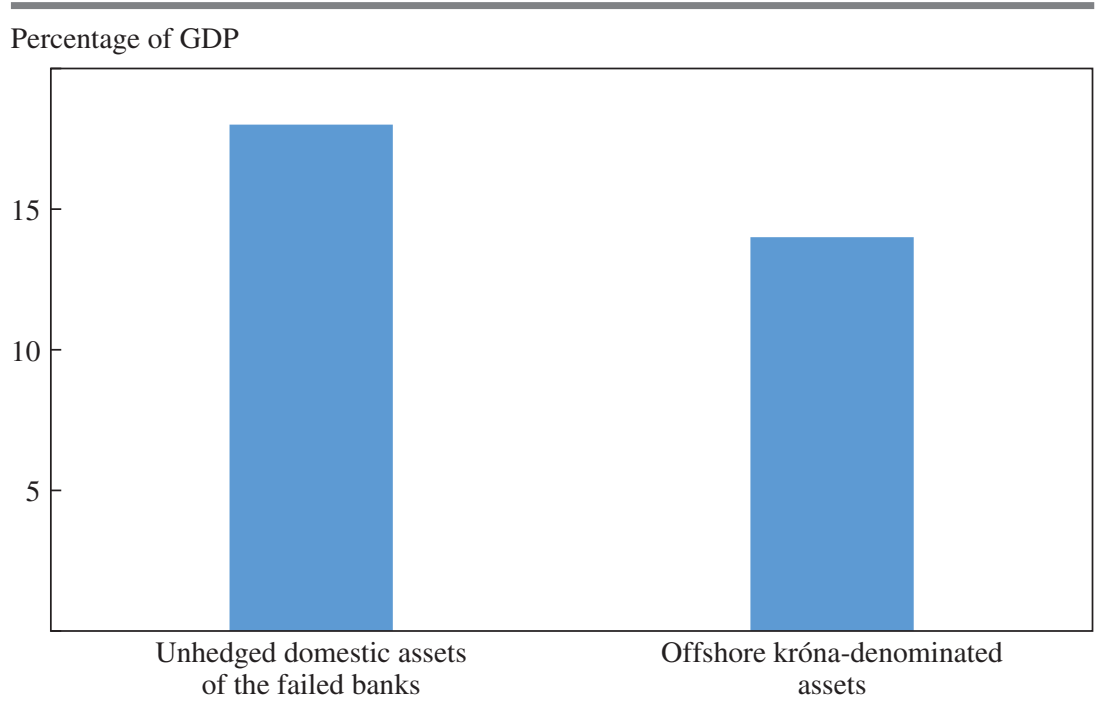

Source: CBI (2016b).

pressures, ongoing external debt deleveraging continued to be a strain on the economy. A key concern was that there was too little latitude for these additional capital outflows, because terms on international financial markets remained very tight after the crisis, forcing domestic firms to aggressively pay down their external debt. Policymakers also judged that the terms in international financial markets would continue to be tight as long as this balance of payments problem was looming (Fitch Ratings 2014; Standard and Poor's 2014).

In 2014, the external debt repayment schedule of the economy was extended with an agreement between one of the new banks and the estate of the old banks. This provided latitude in the near-term external refinancing needed to lower the probability of a default, allowing improved terms on international financial markets for the government and the new banks. Now, the most pressing problem was the potential risk from unwinding the old banks' estates. ${ }^{63}$ As the economy continued to recover, the constraints posed by the capital controls became costlier for firms and individuals, and the government was paying high interest rates on high fiscal debt.

63. The CBI (2013, p. 3) stated, "Before the relaxation of capital controls can even be considered, the settlement of DMBs [old banks] in winding-up proceedings must be placed in a firm framework." 
The capital controls prevented any reimbursements from the estates of the old banks to claimholders, and liquid funds were piling up within the estates in both foreign currency and krónur as the unwinding of assets proceeded. The winding-up boards continued to request exemptions from the capital controls, but the Icelandic government continued to decline these requests on the grounds of risks to the balance of payments, exchange rate, and financial stability (CBI 2016b). The banks' excessive borrowing in foreign markets during the years preceding the crisis had created a systemic risk externality that remained in place years after the borrowing took place and threatened to materialize. This kind of externality is modeled, for example, by Anton Korinek (2014). The question now was, Who should bear the cost of this externality? The Icelandic government pointed the finger at the claimholders.

In June 2015, the government presented stability conditions that would have to be fulfilled before any payout could be made from the estates of the old banks to claimholders. The stability conditions were presented as ensuring macroeconomic and balance of payments equilibrium in the domestic economy. ${ }^{64}$ The claimholders had a great incentive to fulfill the stability conditions, because a large portion of their foreign assets in the estates were already liquid-meaning that the capital controls were the only thing standing between them and the money. An added incentive came from the government's threat that, in the absence of a settlement via the stability contribution, it would impose a 31 percent tax on the estates to "deal with the externality" (Guðmundsson 2016).

The old banks' estates fulfilled the stability conditions through composition agreements in fall 2015. The estates agreed to transfer assets to the Icelandic government. The asset transfer amounted to 18 percent of Iceland's GDP at the time (according to our estimates), or around 20 percent of the total assets of the estates. The stability contribution was payable in domestic assets, including a large domestic commercial bank (CBI 2016b). This, as the government said, removed a major obstacle to lifting the capital controls.

In the next months, the government preceded to minimize the potential risk of the liquid króna assets in the hands of nonresidents, as we show

64. See the Ministry of Finance and Economic Affairs' frequently asked questions on capital controls, available at https://eng.fjarmalaraduneyti.is/capital-controls/q-and-a/. When asked, "What would happen if the capital controls were lifted without preparation?" the ministry responds, "The repercussions of unprepared liberalization would be the collapse of the Icelandic króna, an almost unprecedented surge in inflation, a wave of bankruptcies, and economic instability." 
in figure 46. In May 2016, these investors were invited to participate in a single auction, or to be ring-fenced in deposit accounts with an interest rate of close to zero. About one-third of the total amount was tapped off in the auction, and in direct transactions after the auction, at a 37 percent discount from the official exchange rate (CBI 2016c). The CBI purchased another third of the krónur in 2017 at a 16 percent discount. Currently, the outstanding amount of ring-fenced liquid króna-denominated assets is 3.5 percent of GDP (CBI 2017a, 2017c).

As noted above, the capital controls were lifted for Icelandic firms and the public in the winter of 2016-17.

\section{Lessons}

Iceland is a tiny economy with many unusual features. It is tempting to write off its banking crisis as a one-off saga, a frenzy, that would be unlikely to be repeated anytime soon anywhere else. A frenzy it was, but we think important lessons can be learned.

After the East Asian crisis of the 1990s, when excessive capital flows and increasing leverage also culminated in a banking crisis, there was a tendency for economists to treat such a crisis as a special case, unlikely to be echoed in more developed economies. There was even a special term used to describe those economies: "crony capitalism" (Kang 2002). Presumably, this was meant to separate these economies from "regular" advanced capitalist societies. ${ }^{65}$

As early as 2006, when faced with a minicrisis, Iceland's banks, domestic and foreign commentators, and government all heavily publicized the fact that Iceland was an advanced economy (with the fifth-highest GDP per capita in the world in 2006), with one of the highest life expectancies and literacy rates in the world, nonexistent unemployment, and very low government debt. Furthermore, international indexes were touted showing that Iceland ranked among the highest in low corruption, fifth in economic freedom, first in freedom of the press, and so on. All these accolades meant to convey the overall perception that Iceland was an advanced Nordic country with strong institutions and a well-functioning democracy that had little in common with emerging market countries. This, presumably, was meant

65. Icelanders were particularly fast to reject any likeness, and the Organization for Economic Cooperation and Development and other international institutions did not draw a line between the Icelandic and Asian crises until after the fact, despite all the same warning signs (Tulip 2007; Landler 2008). Gylfason (2008) does, however, compare the external liabilities in Iceland with those in Asia before the crisis. 
to draw a clear distinction from "crony capitalists." What could possibly go wrong?

Iceland's banks grew too fast, and they became too large on the backs of both implicit and explicit guarantees. Their funding was funneled into loans, which to a large extent were made to the same groups of related parties and to insiders - that is, to the banks' owners. In hindsight, the evidence we have presented here suggests that universal rules about large exposures, which are meant to limit concentration risk and are crucial to banks' viability, were broken for years before the banks' failure. The banks' owners had disproportionate access to the banks' funds, despite rules on insider borrowing. How could this happen? Although we have already pointed to one cause-namely, complacency by supervisors and a general view that "the banks are in the best position to regulate themselves"-it is worth highlighting another potential reason.

Nobody in a position of power knew, or in any event had the full picture of, what the banks were doing. Firm ownership in most Western democracies is opaque. The only reason we know how much lending was channeled to groups of related parties and to insiders in Iceland is because of the crash, because Alpingi appointed the SIC—-staffed with, among others, economists, lawyers, and accountants - which, over a period of almost two years, tracked down those who had received the money, and, due to the establishment of a special prosecutor for the failed banks, was able to prosecute the bankers. ${ }^{66}$ This work involved untangling a complex web of holding companies, with several interlocking cross-ownerships, as we have documented.

We have already noted that the pattern of insider lending that we document in Iceland is not unique, pointing out examples such as Ireland and Mexico, even if a detailed cross-country comparison is beyond the scope of this paper. But it is worth noting that these patterns are typically discovered only after bank failures. Monitoring the types of lending to insiders, and coming up with workable definitions of them, remains a major challenge from the perspective of bank supervision, which often must rely on the banks themselves to report these exposures. A lack of firm ownership transparency is one of the principal underlying problems.

66. The special prosecutor investigated 208 cases. Of these, 173 have been processed but 27 are still outstanding; and 46 of the 173 have moved into prosecution process. As of the time of writing, 9 have been settled in courts, all but 2 in favor of the government, and all but 1 going through all stages of the court system, that is, with the Supreme Court issuing a final judgment. Included in the cases that have been settled were charges against the three main banks' chief executives, who were all sentenced to serve prison time (Ríkisendurskoðun 2016). 
This lack of transparency of ownership of companies is not only problematic from the perspective of insider lending but also for large exposures. In 2006 and 2007, it became clear that several of the Icelandic banks' customers had become "too big to fail" for the banks. The banks had an incentive to keep their borrowers "alive," in the hope of resurrection, because a failure of the borrowers could have dragged down the bank itself. This is a bit reminiscent of the "zombie firm" theory of Caballero, Hoshi, and Kashyap (2008) that we discussed in section VII. The narrative, in section III, on the repatriation of many foreign loans of the banks' main customers, as foreign banks stepped away, seems like a clear example of the importance of strongly regulating large exposures. To do this, we need firm ownership transparency, clear and workable rules on large exposures, including how to define groups of firms, along with regulatory powers to enforce the rules.

The heavy practice of banks funding their own and each other's shares gives another important lesson. Issuing loans to buy bank shares-in particular, if banks have correlated risks-will leave the banking system as a whole with less equity to absorb losses, a problem that we have noted is not limited to the Icelandic saga. A key lesson is the need for strong enforcement of rules against banks purchasing or funding their own shares, as well as rules against the cross-funding of financial institutions. Again, opaqueness in firm ownership greatly complicates supervision of rules of this kind.

The Icelandic saga is also a good illustration of the "gamble for resurrection" or "bet on life." Much of the banks' most reckless behavior was happening at the bitter end, which greatly increased the cost to their creditors and the economy as a whole. The lessons for regulators seems to be to try to develop indicators of bank stress early on so that interventions can be made earlier rather than later.

The banking crisis in Iceland highlights the difference between implicit and explicit guarantees in international banking. The Icelandic government had a strong ex post incentive to bail out deposits in the domestic portion of the banks, while it had little incentive to risk taxpayers' money to bail out depositors in foreign branches. A large discount should be put on any assumed implicit guarantee of nation-states on their own banks' liabilities once those liabilities cross the border.

A second lesson concerning implicit guarantees on short-term liabilities, usually deposits, is that irrespective of the government's incentive to bail out deposits in foreign currency, it may not be credible. The deposits in the Icelandic banks' foreign branches were in foreign currency, and stopping a run on those deposits was way beyond the capacity of the CBI's reserves. This leads us to another potential lesson. 
The Icelandic banking crisis highlights the problem of cross-currency banking. The banks' operations were increasingly in foreign currency, both borrowing and lending, while the lender of last resort was the CBI. ${ }^{67}$ Once the crisis hit, the banks quickly became illiquid in foreign currency, and with no lender of last resort in foreign currency, they were bound to fail, irrespective of whether they were solvent or not. In fact, the Icelandic banks never ran out of Icelandic krónur - as we have documented. What they lacked was a lender of last resort in euros, pounds sterling, dollars, and so on. We documented that the banks did have some access to the ECB via their subsidiaries in Luxembourg. However, as the Icelandic banks' borrowing increased, the ECB made it clear that this was already beyond what it considered an acceptable amount, even for a loan of last resort. Meanwhile, many other countries solved issues of this kind by entering swap line arrangements between different central banks. Despite desperately trying to do so, the CBI was unable to enter into such agreements with any foreign central banks. In theory, therefore, once banks are allowed to operate in different currencies or across borders, they can become victims of selffulfilling runs simply because they do not have access to a lender of last resort that uses the currency in which they operate (see also the discussion in Benediktsdottir, Danielsson, and Zoega 2011). ${ }^{68}$

The economic literature on capital flows is also very relevant to the Icelandic story. Capital inflows rose quickly in the years before the crisis. Borrowing from abroad increased exponentially, led by the Icelandic banks, which funneled the funds to firms and households. This capital inflow bonanza increased the likelihood of a full-blown financial crisis. As the crisis hit, the sudden stop threatened the solvency of local governments, firms, and households. The Icelandic case is a vivid example of how capital inflows can amplify economic fluctuations, and it also illustrates that looming capital flight also greatly complicates policy. A key lesson is that more attention needs to be paid to capital flows, and policy tools need to be developed to respond to them.

67. The lender of last resort of subsidiaries is the hosting central bank. The subsidiaries of the Icelandic banks, however, did not receive loan-of-last-resort funding for their subsidiaries, and requests for such loans were declined. As one bank manager said, "The Bank of England refused to see us [Kaupthing Singer \& Friedlander] as a British bank" (SIC, chap. 20, p. 170).

68. Iceland has implemented strict rules on term conversion in foreign currency, within the framework of liquidity rules. It requires a liquidity coverage ratio in foreign currency and net stable funding ratio in foreign currency as well. This is also used as a means to prevent collecting foreign deposits, by requiring banks to hold fully liquid assets against foreign deposit liabilities, making such collecting unsustainable. 
We are not in a position to judge the extent to which any legal lessons can be drawn from the crisis. Let us just note, however, that both Icelandic courts and the European Free Trade Association's court have written judgments that gave governments extraordinary latitude to take actions to maintain financial stability during systemic crises of these proportions.

In the eye of the storm, lessons are also important. One relates to how the banks' assets and liabilities were split up; but in retrospect, the decision to split the banks into foreign and domestic entities appears to have worked well. It kept domestic banking services in operation during the crisis without overextending government finances. Despite being one of the most fiscally expensive crises historically in gross terms, the net fiscal cost will likely end up being somewhere between 0 and 5 percent of GDP. Still, there are some lessons to be learned from the splitting up of the banks. First of all, it was well known in 2008 that the banks were struggling. It would have been prudent to have a resolution plan in place. Second, it is important to consider other things besides capital when laying the foundation for a new bank. More consideration should have been given to important features of the new banks, such as their term mismatch and liquidity, their asset encumbrance, and their currency mismatch. ${ }^{69}$

The write-downs that were done as the new domestic banks were formed were undoubtedly important, providing scope to clean up firms' balance sheets without affecting the new banks' capital and to prevent, in some instances, the costly process of bankruptcy. It is worth noting that a big portion of the write-down to individuals occurred due to a court decision on the illegality of currency-indexed loans.

Although the capital controls appear to have stabilized the currency, they did remain in place for an extended period, along with associated distortions. We discussed in section IX that the main reasons for this were concerns about capital flight, an associated collapse of the currency, and possible risks to financial stability. The necessary steps to resolve these

69. Due to term mismatch, the new banks needed liquidity support for some time following their establishment. The encumbrance of two of the three new banks was so high that it could have caused problems if a second wave of the crisis had hit, lowering the amount of assets available for the government to minimize depositors' losses. This increased the fiscal risk associated with the government-backed guarantee on domestic deposits. All the liabilities in foreign currency, excluding deposits in foreign currency in branches in Iceland, were left in the old banks, while some of the domestic assets that were transferred to the new banks were in foreign currency. This meant that the old banks were short on foreign currency, an issue that was resolved with a stability contribution, while the new banks were long on foreign currency. This situation was partially solved by the government injecting a portion of their equity, in the form of subordinated debt in foreign currency. 
risks were understood as early as 2013 (CBI 2013). The government issued the stability conditions two years later, in the middle of 2015. The old banks' estates fulfilled them, however, only a few months later. The capital controls were almost fully lifted, without any noticeable risk materializing, about a year later. Because the main ingredients in the so-called stability conditions were already understood as early as 2013 , it seems quite possible that the controls could have been lifted more rapidly - thus possibly further speeding up the economic recovery.

Iceland's recovery from the crisis also hints at several broad lessons. Iceland suffered the largest banking crisis on record, in terms of the size of the failed banks' balance sheets relative to GDP. The output cost of the banking crisis appears, however, close to average, according to various measures we document in section VII. We think that four things may be important to explain this. First, the recovery was to some extent reliant on large-scale default and subsequent write-offs of private external liabilities, which was one of the bases for the newly established financial system. ${ }^{70}$ Second, a long tradition in economic thought highlights that in case of a banking crisis, it is of vital importance to clean up firms' overleveraged balance sheets. As we have documented, this was done relatively aggressively in Iceland, which may account for some of the recovery. Third, household debt deleveraging has been emphasized in the literature as important to speed up recovery. Here, too, the Icelandic saga provides an interesting example. Fourth, the theory on optimal currency areas emphasizes the benefit of a country having its own currency when shocks hit. It seems quite plausible that this played a constructive role in the recovery.

\section{Conclusions}

In this paper, we have documented the rise and fall, and then the resurrection, of banking in Iceland, which was sort of a ground zero in the recent global financial crisis, when its entire banking system failed. We have not attempted to present a quantitative or formal model to estimate the importance of various forces at play during the Icelandic crisis. This is by design. Instead, we have presented the Icelandic crisis as a fascinating case study that serves to highlight several macroeconomic models that address finance

70. Many of the write-offs were borne by creditors outside of Iceland, as we have documented. This may have played some part in the output recovery, and it may limit somewhat the extent to which the Icelandic response can be thought of as a role model. It may be difficult in many cases to limit write-offs to this extent to investors and individuals outside the economy in question. 
and banking, thus speaking to a rich literature developed both before and after the crisis.

It is sometimes said that the global financial crisis caught the economics profession by total surprise. It is true that most economists where caught by surprise. But as we have seen, several features of this particular case study of Iceland do in fact correspond quite closely to several theories that can be found in the economics literature. Perhaps what was missing was not so much theories about banking, finance, and macroeconomics that explain the potential risks and possibility of a crisis. What was missing was that economists and others were not giving the relevant theories enough thought.

ACKNOWLEDGMENTS We thank the editors, Janice Eberly and James Stock, for their guidance in the writing of this paper; Jón Steinsson and Kathryn Dominguez, for their helpful comments; Austin Drukker and Alfred Imhoff, for editorial help and superb copyediting; and Karl Aspelund, Josef Platzer, Luca Riva, and Ian Tarr, for excellent research assistance. 


\section{References}

Acharya, Viral V., Sreedhar T. Bharath, and Anand Srinivasan. 2007. "Does IndustryWide Distress Affect Defaulted Firms? Evidence from Creditor Recoveries." Journal of Financial Economics 85, no. 3: 787-821.

Akerlof, George A., and Paul M. Romer. 1993. "Looting: The Economic Underworld of Bankruptcy for Profit." Brookings Papers on Economic Activity, no. 2: $1-73$.

Arena, Marco, Rina Bhattachaya, and Uwe Böwer. 2017. "Iceland: Selected Issues." Country Report no. 17/164. Washington: International Monetary Fund.

Arion banki. 2017. "Announcement of Results of Share Placing.” Press Release, March 3. Reykjavik. https://www.arionbanki.is/english/about-us/media/news/ news-item/2017/03/19/Announcement-of-results-of-share-placing/

BBC. 2008. "Iceland Nationalises Glitnir Bank.” BBC News, September 29.

Benediktsdóttir, Sigríður, Margrét V. Bjarnadóttir, and Guðmundur A. Hansen. 2016. "Large Exposure Estimation through Automatic Business Group Identification." Annals of Operations Research 247, no. 2: 503-21.

Benediktsdóttir, Sigridur, Jon Daníelsson, and Gylfi Zoega. 2011. "Lessons from a Collapse of a Financial System." Economic Policy 26, no. 66: 183-235.

Benigno, Pierpaolo, Gauti B. Eggertsson, and Federica Romei. 2014. "Dynamic Debt Deleveraging and Optimal Monetary Policy.” Working Paper no. 20556. Cambridge, Mass.: National Bureau of Economic Research.

Bernanke, Ben S. 2005. "The Global Saving Glut and the U.S. Current Account Deficit." Remarks given at the Sandridge Lecture, Virginia Association of Economists, Richmond, March 10.

2015. The Courage to Act: A Memoir of a Crisis and Its Aftermath. New York: W. W. Norton.

Boland, Vincent. 2017. "Ireland's 'De-Globalised' Data Calculate a Smaller Economy." Financial Times, July 18.

Boyd, John H., and Hendrik Hakenes. 2014. "Looting and Risk Shifting in Banking Crises." Journal of Economic Theory 149: 43-64.

Bracke, Thierry, and Michael Fidora. 2008. "Global Liquidity Glut or Global Savings Glut? A Structural VAR Approach.” Working Paper no. 911. European Central Bank.

Brunnermeier, Markus K. 2009. "Deciphering the Liquidity and Credit Crunch 2007-2008." Journal of Economic Perspectives 23, no. 1: 77-100.

Caballero, Julián A. 2016. "Do Surges in International Capital Inflows Influence the Likelihood of Banking Crises?” Economic Journal 126, no. 591: 281-316.

Caballero, Ricardo J., Takeo Hoshi, and Anil K. Kashyap. 2008. “Zombie Lending and Depressed Restructuring in Japan." American Economic Review 98, no. 5: 1943-77.

Calavita, Kitty, Robert Tillman, and Henry N. Pontell. 1997. "The Savings and Loan Debacle, Financial Crime, and the State." Annual Review of Sociology 23, no. 1: 19-38. 
Calvo, Guillermo A. 1998. "Capital Flows and Capital-Market Crises: The Simple Economics of Sudden Stops." Journal of Applied Economics 1, no. 1: 35-54.

CBI (Central Bank of Iceland). 2008a. Financial Stability. Reykjavik. https:// www.cb.is/publications/publications/publication/2008/07/29/Financial-Stability2008/

2008b. "Information on Payment Intermediation to Iceland via the Central Bank of Iceland.” Press Release, November 17. https://www.cb.is/publicationsnews-and-speeches/news-and-speeches/news/?NewsID=58deef1c-622b-49ac808e-5683aba3753f

- 2010. Economy of Iceland. Reykjavik. https://www.cb.is/publications/ publications/publication/2010/10/07/Economy-of-Iceland-2010/

- 2012. Financial Stability, no. 1. Reykjavik. https://www.cb.is/publications/ publications/publication/2012/03/29/Financial-Stability-2012-1/

_. 2013. Financial Stability, no. 1. Reykjavik. https://www.cb.is/publications/ publications/publication/2013/03/29/Financial-Stability-2013-1/

- 2015. Financial Stability, no. 1. Reykjavik. https://www.cb.is/publications/ publications/publication/2015/07/29/Financial-Stability-2015-1/

— 2016a. Economy of Iceland. Reykjavik. https://www.cb.is/publications/ publications/publication/2016/10/13/Economy-of-Iceland-2016/

- 2016b. Financial Stability, no. 1. Reykjavik. https://www.cb.is/publications/ publications/publication/2016/04/20/Financial-Stability-2016-1-published/

_.2016c. Financial Stability, no. 2. Reykjavik. https://www.cb.is/publications/ publications/publication/2016/10/12/Financial-stability-2016-2/

. 2017a. "Central Bank Purchase of Offshore Króna Assets." News Report no. 20/2017, June 23. Reykjavik. https://www.cb.is/publications/news/news/ 2017/06/23/Central-Bank-purchase-of-offshore-krona-assets/

_. 2017b. Financial Stability, no. 1. Reykjavik. https://www.cb.is/publications/ publications/publication/2017/04/06/Financial-Stability-2017-1/

. 2017c. “Offshore Króna Assets as of End-2016.” News Report no. 2/2017, January 13. Reykjavik. https://www.cb.is/publications/news/news/2017/01/13/ Offshore-krona-assets-as-of-end-2016/

Chari, V. V., and Patrick J. Kehoe. 2016. "Bailouts, Time Inconsistency, and Optimal Regulation: A Macroeconomic View." American Economic Review 106, no. 9: 2458-93.

Christiansen, Lars. 2006. "Iceland: Geyser Crisis." Research Note, March 21. Copenhagen: Danske Bank. (Reprinted in Preludes to the Icelandic Financial Crisis, edited by Robert Z. Aliber and Gylfi Zoega. New York: Palgrave Macmillan, 2011.)

Congressional Budget Office. 2016. "Report on the Troubled Asset Relief Program-March 2016." Washington. https://www.cbo.gov/publication/51378

Crimmins, Carmel, Andras Gergely, and Jonathan Saul. 2009. "Anglo Irish Lent 'Golden Circle' 451 Million Euros.” Reuters, February 20.

Diamond, Douglas W., and Philip H. Dybvig. 1983. "Bank Runs, Deposit Insurance, and Liquidity." Journal of Political Economy 91, no. 3: 401-19. 
Eggertsson, Gauti B., and Paul Krugman. 2012. "Debt, Deleveraging, and the Liquidity Trap: A Fisher-Minsky-Koo Approach." Quarterly Journal of Economics 127, no. 3: 1469-513.

Englund, Peter. 1999. "The Swedish Banking Crisis: Roots and Consequences." Oxford Review of Economic Policy 15, no. 3: 80-97.

Fitch Ratings. 2006. "Iceland-Macro Imbalances Trigger Negative Outlook." Special Report, February 21. New York. (Reprinted in Preludes to the Icelandic Financial Crisis, edited by Robert Z. Aliber and Gylfi Zoega. New York: Palgrave Macmillan, 2011.)

—. 2014. "Fitch Affirms Iceland at 'BBB'; Outlook Stable." Research update, February 7. London. https://www.sedlabanki.is/library/Skraarsafn/Lanamalrikisins/Fitch\%20february\%202014.pdf

Forsætisráðuneytið [Prime Minister's Office]. 2013. "The Decline in Housing Loans" [in Icelandic]. Reykjavik. https://www.stjornarradid.is/media/forsaetisraduneytimedia/media/Skyrslur/hofudstolslaekkun-husnaedislana.pdf

Guðmundsson, Már. 2012. "Crisis and Recovery in Iceland and the Lessons to Be Learnt." Presentation at a meeting with the EU ambassadors, Reykjavik, June 19. https://www.cb.is/publications/news/news/2012/06/22/Speech/

— . 2016. "Iceland's Recovery—Facts, Myths, and the Lessons Learned." Speech given at the Official Monetary and Financial Institutions Forum, London, January 28. https://www.bis.org/review/r160201b.pdf

Guerrieri, Veronica, and Guido Lorenzoni. 2017. "Credit Crises, Precautionary Savings, and the Liquidity Trap." Quarterly Journal of Economics 132, no. 3: 1427-67.

Gylfason, Thorvaldur. 2008. "Events in Iceland: Skating on Thin Ice?” Online article. London: Centre for Economic Policy Research, VoxEU.

Hafliðason, Ragnar, Sigurður G. Valgeirsson, and Porsteinn Marinósson, editors. 2009. Anпиal Report 2009. Reykjavik: Fjármálaeftirlitið [Financial Supervisory Authority]. https://en.fme.is/media/utgefid-efni/FME-Annual-Report-2009.pdf

Hreinsson, Páll, Sigríður Benediktsdóttir, and Tryggvi Gunnarsson, editors. 2010. "Background and Causes of the Icelandic Banks' Collapse in 2008 and Related Events" [in Icelandic]. Report of the Special Investigation Commission. Reykjavik. https://www.rna.is/eldri-nefndir/addragandi-og-orsakir-falls-islensku-bankanna2008/skyrsla-nefndarinnar/

IMF (International Monetary Fund). 2012. "Iceland: Ex Post Evaluation of Exceptional Access under the 2008 Stand-By Arrangement." Country Report no. 12/91. Washington.

Ingves, Stefan, and Göran Lind. 1997. "Loan Loss Recoveries and Debt Resolution Agencies: The Swedish Experience." In Banking Soundness and Monetary Policy, edited by Charles Enoch and John H. Green. Washington: International Monetary Fund.

Jiménez, Gabriel and Jesús Saurina. 2006. "Credit Cycles, Credit Risk, and Prudential Regulation." International Journal of Central Banking 2, no. 2: 65-98.

Johnsen, Gudrun. 2014. Bringing Down the Banking System: Lessons from Iceland. New York: Palgrave Macmillan. 
Johnson, Simon, Rafael La Porta, Florencio Lopez-de-Silanes, and Andrei Shleifer. 2000. "Tunneling." American Economic Review 90, no. 2: 22-27.

Jónsson, Ásgeir. 2009. Why Iceland? How One of the World's Smallest Countries Became the Meltdown's Biggest Casualty. New York: McGraw-Hill.

Jónsson, Ásgeir, and Hersir Sigurgeirsson. 2016. The Icelandic Financial Crisis: A Study into the World's Smallest Currency Area and Its Recovery from Total Banking Collapse. New York: Palgrave Macmillan.

Kang, David C. 2002. Crony Capitalism: Corruption and Development in South Korea and the Philippines. Cambridge University Press.

Kareken, John H., and Neil Wallace. 1978. "Deposit Insurance and Bank Regulation: A Partial-Equilibrium Exposition.” Journal of Business 51, no. 3: 413-38.

Korinek, Anton. 2014. "Regulating Capital Flows to Emerging Markets: An Externality View." Working paper. http://www.korinek.com/download/Capital Flows.pdf

Krugman, Paul. 1991. "Iceland's Exchange Rate Regime: Policy Options.” Working paper. https://www.gc.cuny.edu/CUNY_GC/media/LISCenter/pkrugman/krugmaniceland-1991.pdf

1999. "Balance Sheets, the Transfer Problem, and Financial Crises." International Tax and Public Finance 6, no. 4: 459-72.

Laeven, Luc, and Fabián Valencia. 2012. "Systemic Banking Crises Database: An Update.” Working Paper no. 12/163. Washington: International Monetary Fund.

Landler, Mark. 2008. "Iceland, a Tiny Dynamo, Loses Steam." New York Times, April 18.

La Porta, Rafael, Florencio Lopez-de-Silanes, and Guillermo Zamarripa. 2003. "Related Lending." Quarterly Journal of Economics 118, no. 1: 231-68.

Mian, Atif, Kamalesh Rao, and Amir Sufi. 2013. "Household Balance Sheets, Consumption, and the Economic Slump." Quarterly Journal of Economics 128, no. 4: 1687-726.

Rajan, Raghuram G. 1994. "Why Bank Credit Policies Fluctuate: A Theory and Some Evidence.” Quarterly Journal of Economics 109, no. 2: 399-441.

Reinhart, Carmen M., and Vincent R. Reinhart. 2008. "Capital Flow Bonanzas: An Encompassing View of the Past and Present." NBER International Seminar on Macroeconomics 5: 1-62.

Reinhart, Carmen M., and Kenneth S. Rogoff. 2014. "Recovery from Financial Crises: Evidence from 100 Episodes." American Economic Review 104, no. 5: 50-55.

Ríkisendurskoðun [Icelandic National Audit Office]. 2012. "Government Funding at Financial Institutions following the Banking Collapse" [in Icelandic]. Report to Alpingi. Reykjavik. https://rikisendurskodun.is/wp-content/uploads/2016/01/ fyrirgreidsla_vid_fjarmalafyrirtaeki2.pdf

—. 2016. "Special Prosecutor" [in Icelandic]. Report to Alpingi. Reykjavik. https://rikisendurskodun.is/wp-content/uploads/2016/11/SU-Serstakur-saksoknari. pdf 
Serious Fraud Office. 2017. "SFO Charges in Barclays Qatar Capital Raising Case." Press Release, June 20. London.

Sharpe, Steven A. 1990. "Asymmetric Information, Bank Lending and Implicit Contracts: A Stylized Model of Customer Relationships." Journal of Finance 45, no. 4: 1069-87.

Standard and Poor's. 2014. "Republic of Iceland Outlook Revised to Stable from Negative on Receding Fiscal Risk; 'BBB-/A-3' Ratings Affirmed." Research update, January 24. London. http://www.lanamal.is/GetAsset.ashx?id=3441

Thomas, Richard. 2006. "Icelandic Banks: Not What You Are Thinking." European Credit Research, March 7. New York: Merrill Lynch.

Tulip, Peter. 2007. "Financial Markets in Iceland." Working Paper no. 549. Paris: Organization for Economic Cooperation and Development, Economics Department. 


\section{Comments and Discussion}

\section{COMMENT BY}

KATHRYN M. E. DOMINGUEZ The Icelandic economic saga documented by Sigríður Benediktsdóttir, Gauti Eggertsson, and Eggert Pórarinsson is worth reading, and not just because it is a spectacular economic drama. The saga includes corruption, incompetence, regulatory capture, precipitous asset price movements, and complicated global linkages — all leading to a surprising denouement involving redemption and resurrection. The paper is a detailed case study of how Iceland's banking sector went bad, the ensuing financial and economic crisis, the government's policy responses, and retrospective cost calculations. There is much to learn from the details, though they come a bit at the expense of a broader macroeconomic analysis of what went wrong (and what eventually righted the economy). The case study approach also makes it difficult to distinguish aspects of the saga that were tail events from aspects we have seen before (or do not realize we have seen before).

The paper's rendition of the saga opens with the privatizations of three big banks - Glitnir, Kaupping, and Landsbanki-which led to the dramatic growth of Iceland's financial sector. The authors squarely place blame on the Icelandic government's initial and ongoing hands-off approach to the financing and regulation of the three banks for paving the way for the financial sector's excessive growth and eventual crisis. Less emphasis is put on Iceland's macroeconomic policy environment before the crisis, which could be argued to have had at least as important a role to play, particularly in providing the incentives for massive capital inflows via the króna carry trade. It seems that at least some blame should go to the Central Bank of Iceland (CBI) for keeping interest rates high to support the króna, leading to widening return differentials, which had reached as high as 10 percent in the time before the crisis. 
The focus on the banks in this paper is in part due to the authors' access to the findings of the Special Investigation Commission (SIC), to which Iceland's parliament gave full access to detailed, bank-level data (and subpoena powers), in order to figure out what happened and whether any public employees were to blame (Hreinsson, Benediktsdóttir, and Gunnarsson 2010). Benediktsdóttir, Eggertsson, and Pórarinsson summarize the data in the SIC report, which are in themselves fascinating, extend the analysis of costs by seven years, and draw important retrospective policy lessons.

The detailed bank data shine a bright light on four critical issues that plagued the Icelandic financial system: fictional collateral, inside dealing, underfunded deposit insurance, and the inadequacy of foreign reserves. Bank regulators have long focused on the importance of capital adequacy and bank collateral. It is noteworthy that Iceland's three big banks, on paper, looked relatively healthy by both measures before the crisis. What the SIC learned, after the fact, is that much of the supposed collateral was based on own-funded and cross-funded (among the three big banks) equity shares that immediately became worthless at the first signs of a system-wide banking collapse. The authors document the various ways in which banks were able to hide this self-funding by selling shares to holding companies that were owned by related parties or large customers (which, in turn, received loans to purchase the shares from the originating bank). For regulators, there are clearly lessons to be learned from Iceland's bank shenanigans regarding fictional collateral, though Iceland is not the first country to provide examples. The authors mention Ireland's golden circle scheme as well as Britain's Barclays capital raising case to make clear that Iceland's banks were not the only ones playing fast and loose with collateral.

The CBI and the European Central Bank (ECB) were also directly caught up in the collateral issues. Deposit growth slowed down in fall 2007, as did other sources of funding, which forced the Icelandic banks to borrow from the CBI and the ECB. The creation of collateral for these loans was known as "love letter" trading. The banks would each issue bonds, exchange the bonds with each other, and then post the bonds as collateral for a loan. The ECB figured out this scam fairly quickly, and it very publicly stopped the borrowing. The CBI, interestingly, continued to lend to the banks based on the collateral created by these love letter exchanges right up to the end. The collusion and inside dealing among the three banks extended to their own loan portfolios. The SIC uncovered an extensive web of large exposure loans to a small group of connected parties (with connections to each other as well as to the owners of the three banks). This paper (as well as the SIC 
report) suggests that Icelandic regulators were unaware of the extent of collusion and inside dealing until it was too late, but this sounds a bit like Captain Renault's famous line from Casablanca, "I'm shocked, shocked to find that gambling is going on in here."

One feature of Iceland's situation that may be unique is its inside-yetoutside membership in European financial and monetary institutions. Iceland is not a member of the eurozone or the European Union. But it is a member of the European Economic Area, which meant that it was required to set up a deposit insurance scheme that covered its domestic and foreign currency deposits, which in turn made its banks attractive to European depositors. Indeed, much of the funding for Iceland's big three banks in 2006-07 came from these deposits, which included the mostly U.K. and Dutch deposits in Icesave, a branch of Landsbanki. When Icesave collapsed and it became clear that the insurance fund could not cover the deposits, however, the Icelandic government delayed repayment based on the argument that the original EU directive was never meant to deal with the collapse of an entire banking system. (In 2013, the European Free Trade Association's court backed Iceland's decision to delay the payments.)

The authors argue that Iceland's decision to prioritize domestic deposits in the postcrisis resolution process should not come as a surprise. In circumstances when governments do not have the resources to pay out insurance, they will discriminate against (mostly noncitizen) foreign currency depositors. Markets seem to have also anticipated this, even if the U.K. and Dutch policymakers did not, as foreign currency deposits earned higher interest than did króna deposits in Icelandic banks.

As the collapse of the big three banks in Iceland became imminent, focus shifted to Iceland's foreign reserves. Although the banks had access to krónur via the $\mathrm{CBI}$, most of their operations were in foreign currency. The ECB would not act as a lender of last resort, even to Icelandic bank subsidiaries located in the eurozone, and the banks' deposits that were denominated in foreign currency were eight times the size of the CBI's foreign reserves. Iceland's foreign reserve stock was similar in relative size to those of most advanced economies that can rely on access to swap lines and international capital markets in times of a liquidity shortage. Emerging market economies have built up sizable reserves as a precaution against the combination of negative shocks and exclusion from international financial markets. But it seems that Iceland did not anticipate that they would be in a position where they could not borrow and, as a consequence, held foreign reserves that were well below the IMF's recommended adequacy level before the crisis. Even excluding the banking system's debts, Iceland's 
reserves did not cover total short-term debt at the end of 2013 (International Monetary Fund 2015).

In October 2008, the Icelandic banking sector collapsed for the many reasons detailed in the first four sections of the paper. At this point in the saga, one could be forgiven for assuming the worst: massive output losses, political upheaval, and domestic strife. All these indeed did come to pass, but only briefly. The authors' narrative places the credit for this relatively short-lived reckoning on sure-footed policy reactions, the first of which was a swift bank resolution process involving substantial asset write-downs, no bailouts for creditors, and the immediate recapitalization of "new banks," followed by the imposition of capital controls.

Capital controls seem to have played a critical role in preventing massive capital outflows, a complete collapse of the króna, and a balance of payments crisis. The króna fell by 50 percent in the year before controls were put in place, driven in part by the unwinding of the carry trade. The controls were originally put in place as part of the conditions for an IMF loan, not so much to stem domestic resident capital flight as to restrain the repatriation of the remaining offshore króna carry trade positions as well as the substantial króna-denominated holdings of foreign creditors in the failed Icelandic banks, which together amounted to well over Icelandic GDP. Capital controls allowed Iceland to postpone the liquidation of these holdings, which would have caused a full-on balance of payments crisis. The controls were finally largely removed in 2016, though even after waiting more than seven years to be able to repatriate assets, creditors were forced to take a substantial haircut (in the form of a stability tax) to ensure that the withdrawals would not destabilize the economy.

The authors provide a convincing argument for why capital controls were needed, but they have less to say about exactly how they worked. Empirical evidence from other countries largely suggests that capital controls, especially those imposed temporarily and in times of crisis, are ineffective; when there is an incentive to get money out of a country, people usually find a way to do so. Along with coauthors, I documented the capital flight in Argentina during its experience with capital controls in 2001 (Auguste and others 2006). During that episode, domestic residents who wanted to get their assets out of Argentina purchased crosslisted domestic stocks, converted them to American depositary receipts (at a steep discount), sold them in New York, and deposited the dollar proceeds in U.S. banks. Michael Klein (2012) takes a multicountry panel approach and finds little evidence that temporary controls are effective at restricting cross-border capital flows. In Iceland's case, the crucial detail, 
which is easy to miss in the narrative, is that after the collapse of the big three banks, the CBI served as the sole intermediary for all króna foreign exchange transactions. The capital controls were effective because krónur could not get into or out of Iceland without the CBI's approval.

The quick resolution of the banking crisis, along with strictly enforced capital controls, allowed Icelandic policymakers to stabilize the domestic financial sector, which was already an impressive feat given the severity of the financial collapse; but even more remarkable was the dramatic recovery of the real side of the economy. Iceland's real GDP had returned to precrisis levels by 2015; its current account went from a deficit of 25 percent of GDP to being in balance; and perhaps most impressive, its net international investment now has a surplus after reaching a deficit of over 700 percent in 2009.

One of the key drivers of Iceland's recovery was the current account reversal that coincided with the large króna depreciation. A crash in import demand can explain much of the turnaround; but, curiously, a large spike in tourism also seems to have played an important role. Boosting tourism is generally not thought to be a long-term growth strategy for advanced economies, but tourism revenues are now over 40 percent of total exports in Iceland. To maintain the country's thriving tourism sector, the CBI has resorted to actively intervening in the foreign exchange market (selling krónur for euros), in order to slow down the króna's appreciation. The resurrection of the króna, which started in earnest in 2015, has been remarkable, with the real effective króna exchange rate recently returning to its precrisis level.

This saga is perhaps already too long, but I would have liked to see more discussion of the role of the króna in Iceland's crisis and recovery. If Iceland had been part of the eurozone, it would have had access to ECB liquidity, which might have allowed it to stave off the collapse in the banking sector, and thus it would not have faced the enormous rise in the value of its debt denominated in foreign currency. The carry trade and concomitant capital inflows would also never have come to pass. Conversely, without the benefits of the króna's collapse, Iceland would not have experienced its current account reversal, and it would likely not have experienced the current boom in tourism.

The authors suggest that Iceland could be considered a role model for its speedy recovery. In terms of policy actions, Iceland largely followed textbook recommendations for macroeconomic crisis management: allow depreciation, increase interest rates, and impose fiscal austerity (which it 
did by raising taxes and cleaning up balance sheets). But if we focus on policy in the years before the crisis, the flashing red warning signs were not subtle. The massive carry trade was no secret; nor was the fact that Iceland's banking system was nine times its GDP, while the CBI's reserves were 2 percent of the banks' liabilities. Iceland seems more a cautionary tale than a role model, even given its quick recovery. It may also be that the quick turnaround is less surprising than it seems. A recent analysis by Christina Romer and David Romer (2017) shows that for countries like Iceland, which had both monetary and fiscal policy space at the time of the global financial crisis, the duration of financial distress was substantially lower than for countries without this space.

Along with the outsize growth of the financial sector, it is hard to believe that regulators were unaware of the growing exposures and insider dealings among the big three banks. The authors document that the Financial Supervisory Authority (FSA) did not enforce the existing large exposure rules and allowed banks to self-report which loans were between related parties (they reported that few were). Moreover, the CBI continued to loan to banks after the ECB refused to do so. Was this garden variety or extreme regulatory capture? Cross-country comparisons would be useful here to help us understand whether the CBI and FSA were unusually lax, or whether there are examples in other countries of similar behavior.

The paper provides an extensive analysis of the costs of the crisis, updating Luc Laeven and Fabián Valencia's (2012) output loss calculations for Iceland and Carmen Reinhart and Kenneth Rogoff's (2014) severity index. These updated calculations suggest that the actual costs of recapitalizing the new banks and resolving the old banks' debts were lower than originally anticipated. The authors describe the many thorny issues involved in measuring costs, and similar to the "costs of TARP" debates in the United States, indicate that while the ex ante risks were high, debt write-downs and improved asset valuations led to significantly reduced ex post costs.

The Icelandic saga ends with a number of standard lessons - the dangers of moral hazard, bank balance sheet opacity, and lack of regulatory oversight — along with some new ones, including the dangers of financial sector overdevelopment and bank runs in the absence of a foreign currency lender of last resort. The authors stop short of describing how big is "too big" for a banking system. They also do not focus much on what the CBI and FSA could have done differently, other than enforce the rules 
and regulations that were already in place. Iceland seems to be a good candidate for a more macroprudential approach, with countercyclical capital requirements, a regulatory focus on foreign currency amounts of capital, and requirements for contingent capital and longer-term debt maturities for bank liabilities. Of course, given that regulators did not enforce the old, relatively simple rules, more complicated rules might not be the solution. Another policy issue that the saga does not address is what features of the crisis can be blamed on actions taken by the Icelandic banks and regulators, and what aspects might not have been critical if it had not been for the coincidental timing of the global financial crisis. Finally, the saga leaves unanswered the question of what mattered most for Iceland's recovery: Was it the ability to devalue the króna, the rapid resolution of the banking crisis, and the limited financial sector bailout, or was it the strict enforcement of capital controls that allowed Iceland to postpone debt repayments? The authors instead provide an extraordinarily detailed chronology of the events that led to Iceland's banking crisis and resurrection, enlightening readers with a rich case study that will surely inspire further analyses of this remarkable saga.

\section{REFERENCES FOR THE DOMINGUEZ COMMENT}

Auguste, Sebastian, Kathryn M. E. Dominguez, Herman Kamil, and Linda L. Tesar. 2006. "Cross-Border Trading as a Mechanism for Implicit Capital Flight: ADRs and the Argentine Crisis." Journal of Monetary Economics 53, no. 7: 1259-95.

Hreinsson, Páll, Sigríður Benediktsdóttir, and Tryggvi Gunnarsson, editors. 2010. 'Background and Causes of the Icelandic Banks' Collapse in 2008 and Related Events" [in Icelandic]. Report of the Special Investigation Commission. Reykjavik. https://www.rna.is/eldri-nefndir/addragandi-og-orsakir-falls-islenskubankanna-2008/skyrsla-nefndarinnar/

International Monetary Fund. 2015. "Iceland: Selected Issues." Country Report no. 15/73. Washington.

Klein, Michael W. 2012. "Capital Controls: Gates versus Walls." Brookings Papers on Economic Activity, Fall: 317-55.

Laeven, Luc, and Fabián Valencia. 2012. "Systemic Banking Crises Database: An Update." Working Paper no. 12/163. Washington: International Monetary Fund.

Reinhart, Carmen M., and Kenneth S. Rogoff. 2014. "Recovery from Financial Crises: Evidence from 100 Episodes." American Economic Review 104, no. 5: $50-55$.

Romer, Christina D., and David H. Romer. 2017. "Why Some Times Are Different: Macroeconomic Policy and the Aftermath of Financial Crises." Working Paper no. 23931. Cambridge, Mass.: National Bureau of Economic Research. 


\section{COMMENT BY}

JÓN STEINSSON Sigríður Benediktsdóttir, Gauti Eggertsson, and Eggert Pórarinsson have written a first-rate account of the causes and consequences of the collapse of the Icelandic banking system in the fall of 2008. Their account focuses on the rise and fall of the Icelandic banks, which is a remarkable story. In this comment, I try to provide some context for this story by discussing, in addition to the banking story, a number of macroeconomic developments and policies in Iceland during this period. I frame my comment with four important policy failures and four important policy successes in Iceland before and after the crisis.

POLICY FAILURE 1: BANKING SUPERVISION The most important policy failure by far was the inadequacy of bank supervision before the crisis. The authors cover this well. The short version of the story is that the regulators in Iceland were some combination of completely captured and completely incompetent. Important elements of this regulatory failure are (i) massive lending to related parties, (ii) massive lending to insiders, (iii) fictional equity and stock market manipulation, and (iv) the "love letters." If you have ever wondered what it is like to have a banking system that is effectively unregulated, read this paper carefully.

An interesting question is the extent to which the rapid rise of such poorly functioning banks was partly enabled by Iceland having a reputation for good institutions. Iceland scores well on anticorruption indexes. And it is true that it is not easy to bribe a policeman or a judge in Iceland. This may have led foreign investors to believe that banking regulation in Iceland was strong, which may have contributed to their willingness to lend huge sums of money to banks that were growing extremely rapidly but had almost no track record for the international activities in which they were then engaged. It seems unlikely that such rapid growth in banking, fueled by wholesale funding from international investors, could happen in a country with a reputation for corruption. One thing this episode should teach us is that whether you can bribe a policeman or a judge is not a sufficient statistic for measuring institutional quality.

POLICY FAILURE 2: HOUSING POLICY The fact that over 90 percent of the banking system in Iceland failed in the span of one week suggests that the crisis should have led to a complete macroeconomic calamity. Many macroeconomists believe the Great Depression in the United States was in large part due to banking failures. But much less than 90 percent of the U.S. banking system failed in the Great Depression. So, should the Icelandic banking collapse not have led to a macroeconomic collapse even larger than the Great Depression in the United States? 
Figure 1. Real House Prices in Reykjavik, 1994-2017

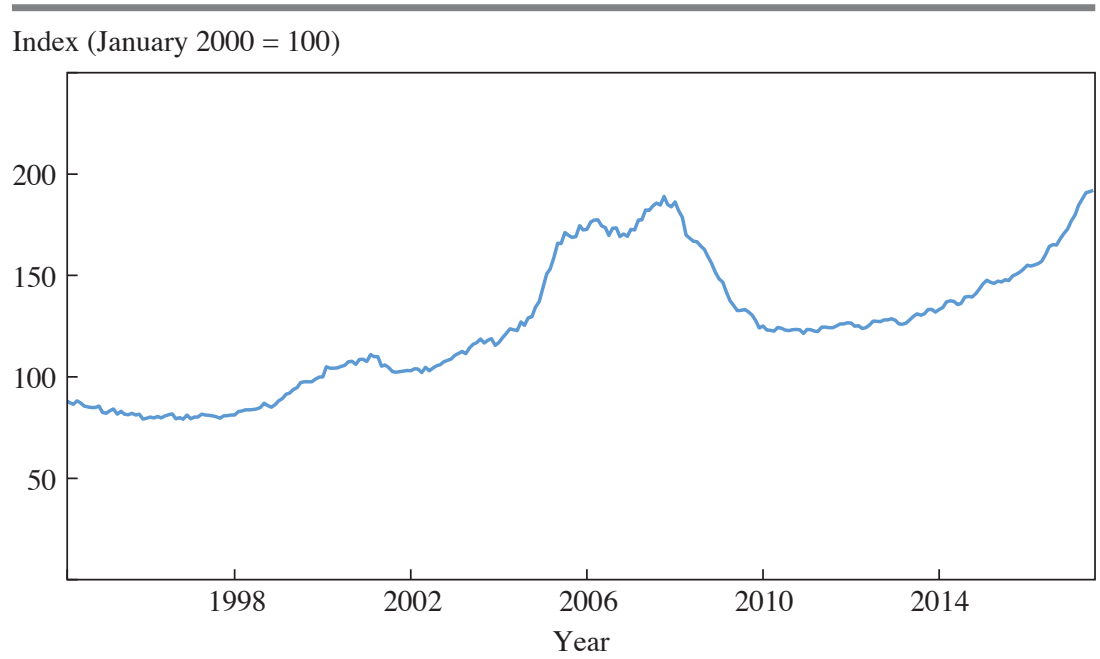

Sources: Registers Iceland; Statistics Iceland.

There are several important differences that explain why this is not the case. One difference is that a large majority of the assets and liabilities of the Icelandic banks were foreign. The three major banks in Iceland had grown by more than a factor of four over a few years before 2008 . But almost all this growth was in foreign operations. The banks funded themselves abroad, and to a first approximation lent all the funds they raised to a small group of Icelandic tycoons who used the funds to purchase assets abroad.

When the banks collapsed, it was because of a run by foreign wholesale investors. The Icelandic authorities quickly reacted by dividing each bank into a domestic part that was well capitalized and a foreign part that was bankrupt. This insulated the domestic economy from the banking collapse to a large degree. Of course, there was quite a bit of disruption. But once the crisis had come to a head, the domestic economy was being serviced by new banks that were well capitalized.

The recession that Iceland experienced in 2008-09 was made much worse than it otherwise would have been by the collapse of a huge housing bubble that had been building up in Iceland during the boom years. My figure 1 plots real house prices in the Reykjavik area from 1994 to 2017. Beginning in 2004, prices rose by more than 50 percent over a few years. In 2008 and 2009, prices collapsed back to their pre-2004 level. The increase 
Figure 2. Sales of Cement in Iceland, 2000-17

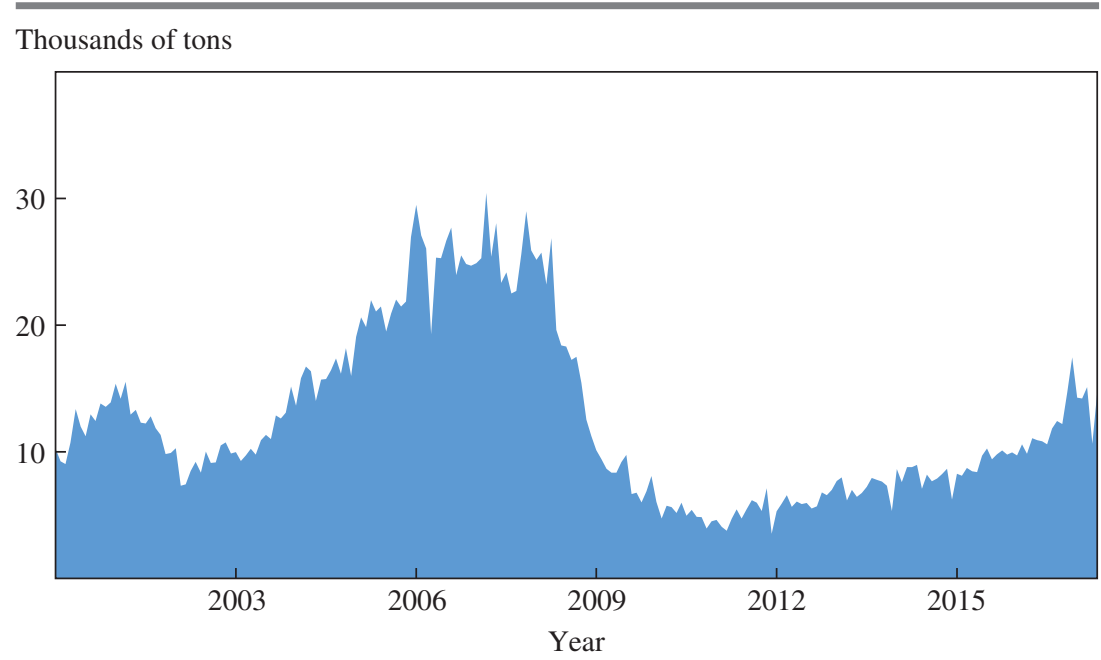

Source: Central Bank of Iceland.

in prices before 2008 led to a boom in housing construction in Iceland. My figure 2 illustrates this by plotting the sales of cement in Iceland from 2000 to 2017. These sales more than doubled from 2004 to 2007. The collapse of the housing bubble then led to a huge collapse in the construction sector in Iceland.

A very large portion of the fall in employment in Iceland between 2008 and 2009 was in construction and real estate. Overall employment fell by 11,000; and of this, 6,600 workers were in construction. (The Icelandic economy is roughly a thousand times smaller than the U.S. economy. Therefore, a fall of employment of 11,000 in Iceland is analogous to a fall of employment of 11 million in the United States.) The fall in employment in the banking sector was a mere 1,000 . This is partly due to the fact that an enormous amount of restructuring had to be done in the banks after the crisis, but also because the new domestic banks had weak incentives to reduce costs since they were first owned by the government and then by the creditors of the old banks (which were not allowed to exercise full control).

Housing policy played an important role in the Icelandic housing bubble. This is the second important policy failure in Iceland over this period. The Progressive Party's aggressive campaign promises in the 2003 parliamentary elections, which it honored once in government, contributed to getting the housing boom started. In 2004, the newly privatized commercial banks 
Figure 3. The Central Bank of Iceland's Real Policy Interest Rate, 2002-17

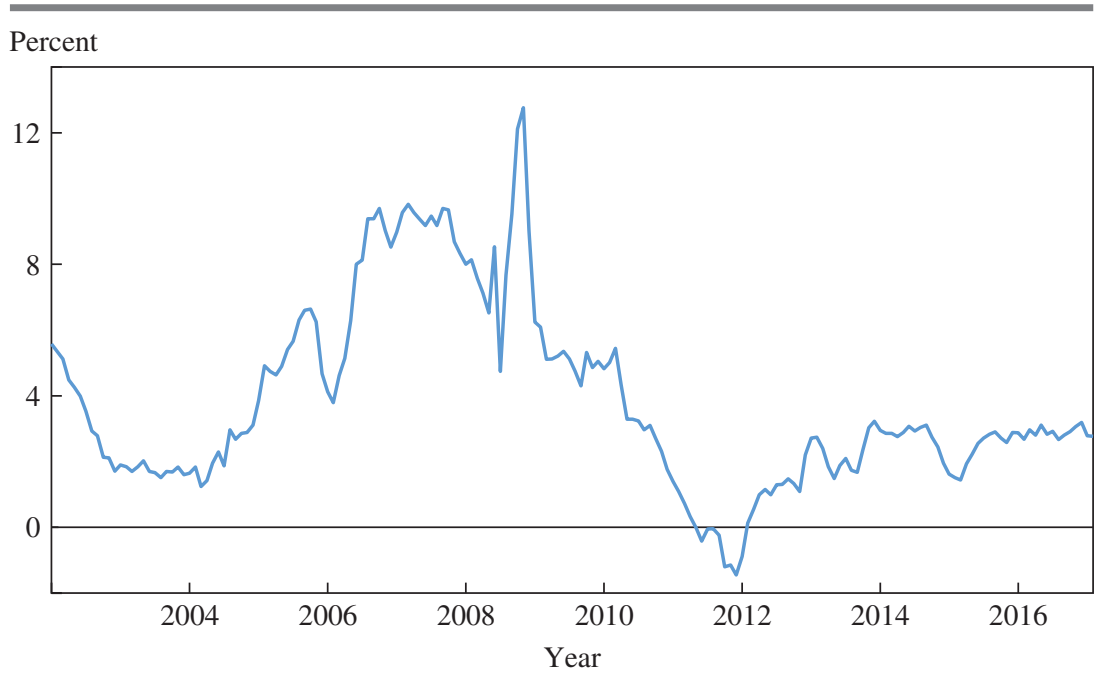

Source: Central Bank of Iceland.

entered the mortgage market and offered much lower interest rates than had previously been available. The banks also offered cash-out refinancing products that had not existed in Iceland before this time. The result was a household lending boom, which likely played a pivotal role in generating the rapid run-up in house prices in Iceland at this time. The government and the Central Bank of Iceland stood by and did little to rein in this housing boom.

POLICY FAILURE 3: MONETARY POLICY BEFORE THE CRISIS The third policy failure has to do with the conduct of monetary policy before the crisis. Icelandic monetary policy in these years was conducted very much in accordance with the conventional wisdom of the time. The central bank adopted an inflation target in 2001. It viewed itself has having a single instrument: the short-term interest rate. There was a big boom, so the central bank raised this interest rate to very high levels. My figure 3 plots the policy rate of the Central Bank of Iceland, less break-even inflation, based on the difference in yield between nominal and real government bills over the period from 2002 to 2017 . This real policy interest rate is incredibly high for a sustained period before the crisis. It is above 4 percent continuously from mid-2005 until well after the crisis, and it is above 8 percent for several years after mid-2006. The average real policy rate between June 2004 and June 2008 is an astonishing 7.4 percent. 
Figure 4. The Króna Real Exchange Rate, 1991-2017

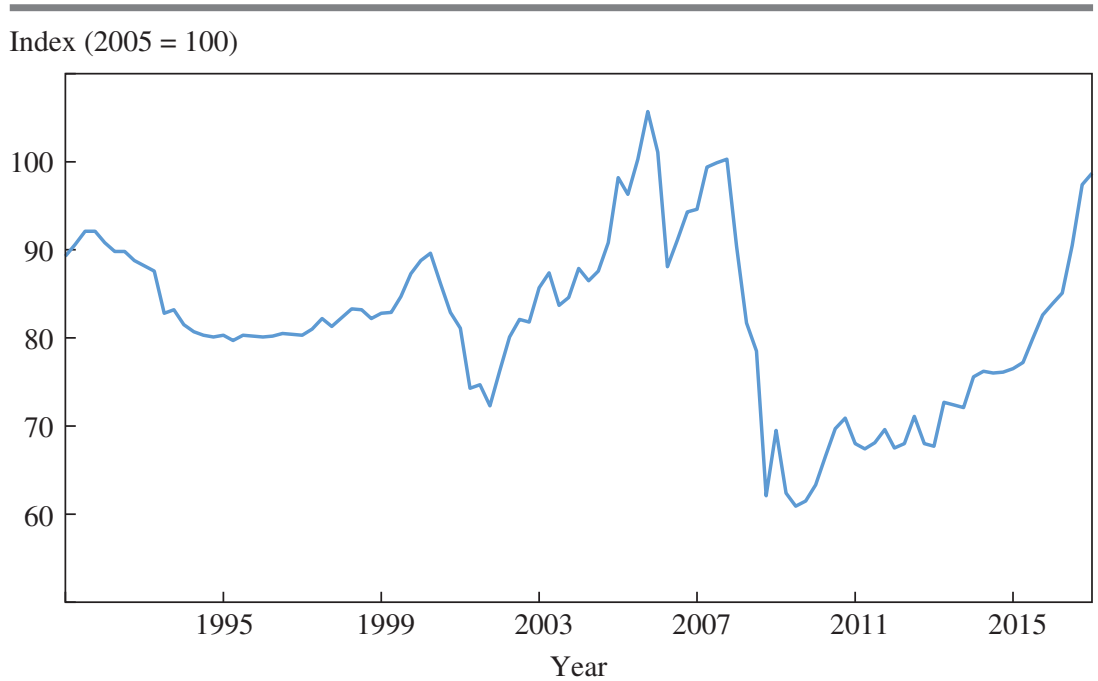

Source: Central Bank of Iceland.

One consequence of this high interest rate policy was a rapidly appreciating exchange rate and extremely high returns on the Icelandic króna relative to foreign currency. My figure 4 plots the real exchange rate of the króna from 1991 to 2017. From fall 2002 to fall 2007, the real exchange rate appreciated by 22 percent. The huge returns on the króna-or, conversely, the very low returns on foreign currency-led to a massive boom in foreign currency borrowing in Iceland during this period. By 2006, virtually all car loans in Iceland were issued in foreign currency, and a rapidly increasing share of mortgages were also in foreign currency. Foreign currency borrowing by the corporate sector was also endemic, even in sectors that had no revenue in foreign currency. This foreign lending boom led to a very large current account deficit, which peaked at almost 25 percent of GDP in 2006 (see my figure 7 below).

In retrospect, it is not clear to me that this type of monetary policy was the most effective way to contain the boom. The high interest rates may have encouraged capital inflows, and thereby had the perverse effect of feeding the boom as opposed to dampening it. The conventional wisdom at the time was not favorable to other policy instruments, such as foreign exchange intervention, capital controls, restrictions on currency carry trades, and lending in foreign exchange. I was then a believer in 
this conventional wisdom, but over the past decade I have become more favorably inclined toward some of these other instruments. Since the crisis, the Central Bank of Iceland has revised its framework for conducting monetary policy and has substantially increased the role of foreign exchange interventions, certain forms of capital controls, and restrictions on carry trades and lending in foreign currency. I think these are steps in the right direction.

POLICY FAILURE 4: NOT MAKING INSURED DEPOSITS SUPERPRIORITY CLAIMS The fourth and final policy failure is a bit technical. An important element of the Emergency Act that was passed at the height of the crisis was a provision that reordered the priority of claims in the banks. It made deposits a priority claim relative to other bank debt, as is the case in the United States but not in most of Europe. Something that was not done, but could have been done equally easily, was to give insured deposits superprioritythat is, to order them above other deposits. In the United States, insured deposits have such superpriority.

If Iceland had done this, it would likely have avoided the whole "Icesave dispute" between Iceland, Britain, and the Netherlands. The reason is that if insured deposits had had superpriority, it would have been clear that the bankrupt old banks had enough assets to eventually pay these claims in full. Although the Icesave dispute was eventually decided in Iceland's favor, it consumed an enormous amount of very scarce political energy in Iceland in the aftermath of the crisis, and it created a great deal of uncertainty about the country's fiscal situation. It also fanned the flame of nationalism and populism in Iceland during this period.

Why did the Emergency Act not include a superpriority provision for insured deposits? I participated directly in the events that led to the passing of the Emergency Act. As far as I can tell, the reason why this was not done is simply that none of us thought of it. It was simply a mistake.

POLICY SUCCESS 1: THE EMERGENCY ACT Let us now turn to policy successes. The most important policy success in Iceland, in my view, was the Emergency Act. This law was passed right before midnight on October 6, 2008. The bill had been introduced in Alpingi only that afternoon, after a televised address to the nation by the prime minister. It had been drawn up very quickly, with little preparation.

The Emergency Act contained two main elements: (i) It reordered the priority of claims in the banks, giving deposits priority relative to other debt liabilities; and (ii) it gave the Financial Supervisory Authority wideranging resolution authority over the banks in the event that they failed. The law was passed in the nick of time. The resolution authority was used 
the next day to place two of the three main banks in receivership, and two days later for the third bank.

The law's resolution authority provision allowed for an orderly resolution of the banks when they failed. As mentioned above, in each case, the banks were divided up into a well-capitalized "new bank" and a bankrupt "old bank" (see the authors' figure 27). The bulk of domestic assets of the old bank were transferred to the new bank, as well as all domestic deposits. Care was taken to transfer enough assets into the new banks to make sure that they were well capitalized.

This splitting of the banks meant that the sovereign did not assume any of the liabilities of the banks. The creditors of the old banks bore all the losses. Initially, the government purchased the new banks with newly issued domestic government debt. But eventually, in the case of two of the three banks, ownership of the new bank was transferred to the old bank. That is, instead of the government purchasing the new bank, the new bank became one of the main assets in the old bank's bankruptcy proceedings. And because the losses in the banks were not nationalized, the government remained solvent and did not end up having to use much of its fiscal room for the bank restructuring.

A second important consequence of the way the bank resolution was handled was that the banks remained open for business throughout the crisis. This was crucial for minimizing disruptions to the real economy. There were never any lines at ATMs, there was no stockpiling of food, everyone got paid on time, firms continued to get working capital loans and were able to pay their bills, and the like. This was particularly impressive in light of the fact that a very large fraction of the largest Icelandic firms were technically insolvent after the crash. Many of these firms had set up investment companies (essentially hedge funds) as side businesses, and these companies incurred huge losses during the crisis. This was true of the country's main airline, shipping company, newspaper, supermarket chain, and the like. All these firms needed financial restructuring, but they all had a viable core business. The new banks were able to allow all these firms to operate normally, despite the sorry state of their balance sheets. Over the next year or so, the banks took these firms through a financial restructuring process, and in many cases a change of ownership.

I remember vividly that during our initial contacts with officials of the International Monetary Fund right before the Emergency Act was passed, the IMF staff members warned us that we needed to plan for riots, food shortages, bank runs, and the like. After all, the plan was to let all the banks in the country go bust simultaneously. I was taken aback. I even spent time 
Figure 5. Icelandic Gross Government Debt as a Percentage of GDP, 2000-16

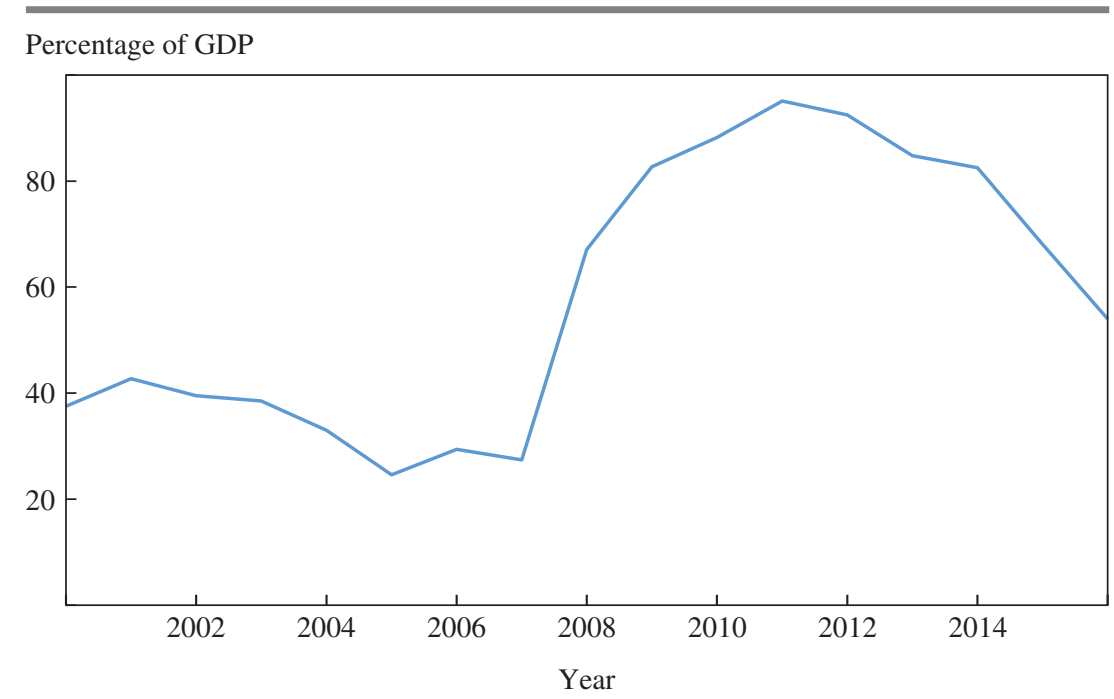

Source: Statistics Iceland.

worrying about these things. But none of this happened. The reason, I think, is that in no small part, the Emergency Act's resolution authority provision allowed for a smooth transition from the old banks to the new ones.

POLICY SUCCESS 2: FISCAL ROOM The second important policy success was fiscal policy before the crisis. Iceland's experience during the crisis vividly illustrates the value of fiscal room. The government came into the crisis with very little debt. My figure 5 plots gross government debt in Iceland as a percentage of GDP from 2000 to 2016. In 2007, gross government debt was only 25 percent of GDP. This allowed the government to run huge deficits after the crisis, which was important in smoothing out the crisis.

My figure 6 plots the Icelandic government's budget balance from 2000 to the present as a percentage of GDP. The government was running a surplus of roughly 5 percent of GDP in 2006 and 2007. In 2008, however, the government ran a deficit of 13 percent of GDP. The deficit remained large in 2009 and 2010, at roughly 10 percent of GDP each year. Only in 2011 did the government start to reduce the deficit substantially, and not until 2014 did it again run a surplus. From 2007 to 2011, the ratio of government debt to GDP rose by 70 percentage points. This was, of course, only possible because debt was low to begin with. 
Figure 6. The Icelandic Government's Budget Balance as a Percentage of GDP, 2000-16

Percentage of GDP

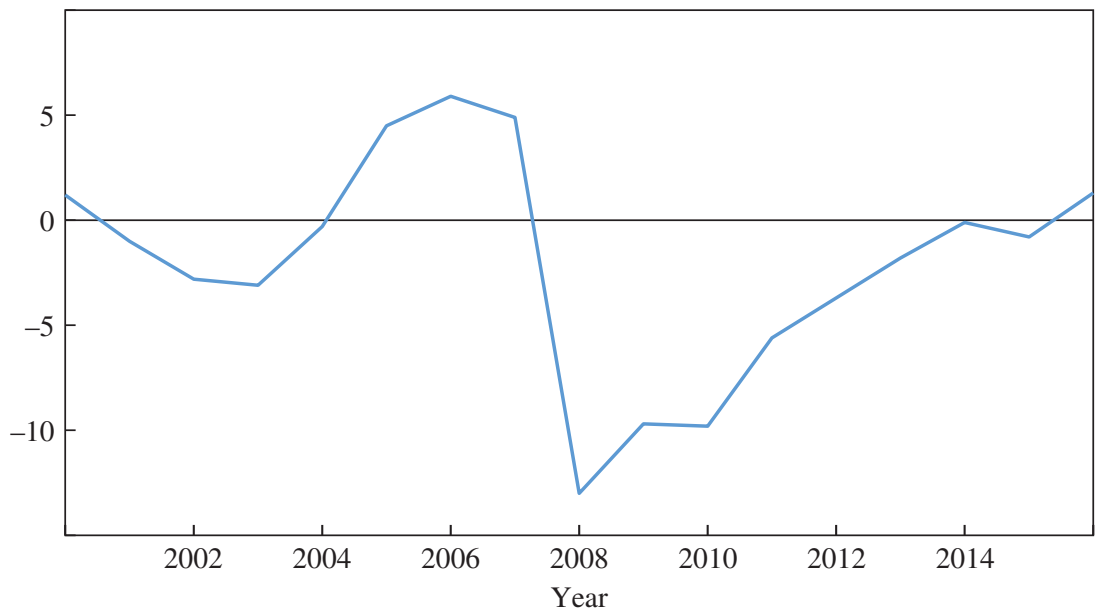

Source: Statistics Iceland.

It is hard to overemphasize the value of the government being able to run such enormous deficits for multiple years after the crisis. This allowed the government to shield the welfare system in Iceland from the draconian cuts that otherwise would have been necessary. Tax revenue, of course, collapsed at the time of the crisis. The budget deficits in the years 2009-11 were therefore mainly due to the government not cutting spending as much as tax revenues fell. This is not to say that the government was able to avoid cutting spending. Spending was cut a great deal. But the scale of spending cuts that would have been necessary to avoid large deficits in the short run would have been a great deal more painful if not for the ability to run large deficits-and likely would have exacerbated the recession by a nontrivial amount.

Eventually, the government had to get the budget under control. This was done gradually. Tax revenues did start to recover, which helped. But the government did also engage in a gradual austerity policy to eventually return to a balanced budget. Again, gradual austerity is much less painful than shock-and-awe austerity.

POLICY SUCCESS 3: CAPITAL CONTROLS The third policy success was capital controls. These were imposed after the crisis with strong prodding from the IMF. At the time, I opposed this policy. My view was based on the fact that Iceland had already defaulted on most of its foreign liabilities. 
Foreign liabilities were therefore limited. Keeping the capital account open after the crisis would likely lead to a mass exodus of foreign investors from Iceland, and these investors might sell their Icelandic assets at fire-sale prices. This would likely benefit some savvy Icelanders, who would be on the buying side.

I also thought that it would be good to let the dust settle regarding the overhang of Icelandic assets held by foreigners. If this was not done initially, these foreign liabilities would remain an unresolved issue that would potentially lead to a long delay in returning to capital account convertibility. The previous instance when capital controls were imposed in Iceland was during the Great Depression. Then, the controls remained in place for over half a century.

I have since changed my mind about this. Now, I think imposing capital controls was crucial. The government needed to finance very large deficits. The imposition of capital controls locked a considerable amount of foreign capital in the country. It stands to reason that these funds substantially lowered the government's financing cost, and it is unlikely that the government could have done nearly as much deficit spending without capital controls.

Furthermore, without the capital controls, there could have been more general capital flight from Iceland, with Icelanders moving a substantial amount of capital out of the country. The extent to which this happened would have depended on Icelanders' confidence in the government's macroeconomic policies. It is easy to imagine a self-fulfilling crisis, where a lack of confidence in Icelandic macroeconomic policy could have led to capital flight, which in turn made sound policy too costly to implement (Calvo 1988). My current view is that the risk of this type of bad, self-fulfilling equilibrium was very real, and that imposing capital controls allowed the country to insulate itself from this outcome.

Imposing capital controls was of course an act of financial repressiona way for the Icelandic government to tax foreign investors and wealthy Icelanders. But at that time, the Icelandic government badly needed this source of revenue. Moreover, an argument can be made that capital controls were an element of an optimal fiscal response to the banking crisis. Capital controls are similar to an ex post, lump sum tax on capital. Such taxation is efficient as long as it does not have excessively detrimental effects on the government's reputation. Though such reputational costs are hard to estimate precisely, from today's vantage point, the reputational costs of Iceland's capital controls seem relatively small.

POLICY SUCCESS 4: DEVALUATION The fourth and final policy success is monetary policy during the crisis. Iceland has its own currency. It was 
therefore able to allow the currency to depreciate substantially at the time of the crisis. Looking back at my figure 4, we can see that the Icelandic real exchange rate depreciated by 40 percent from the fourth quarter of 2007 to the third quarter of 2009. And the nominal exchange rate depreciated even more.

The depreciation of the exchange rate had two main benefits. First, it allowed for some inflation in Iceland, which lowered real wages "without bloodshed," as a domestic commentator put it. This was particularly important for the public sector, because it helped the government get the budget under control.

The second benefit was that the depreciation allowed for substantial expenditure switching toward Icelandic goods. My figure 7 shows the evolution of the current account balance in Iceland from 1997 to 2016, with a breakdown into the balance on goods, services, and capital income. As I discussed above, the boom years were characterized by a huge amount of net foreign borrowing. In the four years leading up to the crisis, the current account deficit averaged 17 percent of GDP. In 2009, however, the current account swung sharply upward, from a deficit of 16 percent of GDP to a surplus of 8 percent of GDP. ${ }^{1}$ This large swing in the exchange rate was crucial to this large reversal.

In the short run, the expenditure switching occurred mostly on the import side. People stopped buying durable goods (and the Icelandic banks stopped servicing their debts). My figure 8, my favorite visual portrayal of the Icelandic crisis, plots monthly new car registrations in Iceland from 2000 to 2017. During the crisis, new car registrations fell to virtually zero. The number of new car registrations fell 94 percent from November 2007 to November 2008. Actually, a law was passed to allow for the reexporting of newly imported cars that were sitting at the dock when the crisis occurred. The story for other durable goods is similar.

This strong response of durable goods imports is helpful in thinking about modern economies' ability to cope with this kind of event. My figure 9 plots GDP growth and the growth in consumer expenditures in Iceland from 2000 to 2016. The cumulative fall in consumer expenditures was roughly 20 percent in 2008 and 2009. A 20 percent fall in consumption

1. These numbers are corrected for the effects of the old banks on the balance of income. Some official current account calculations for Iceland indicate a current account deficit after the crisis. This is because these calculations count capital income payments from Iceland to the rest of the world relating to the old banks. These payments never occurred because these banks were bankrupt. The numbers in my figure 7, which are from the Central Bank of Iceland, do not count these payments. 
Figure 7. The Icelandic Current Account Balance, 1997-2016

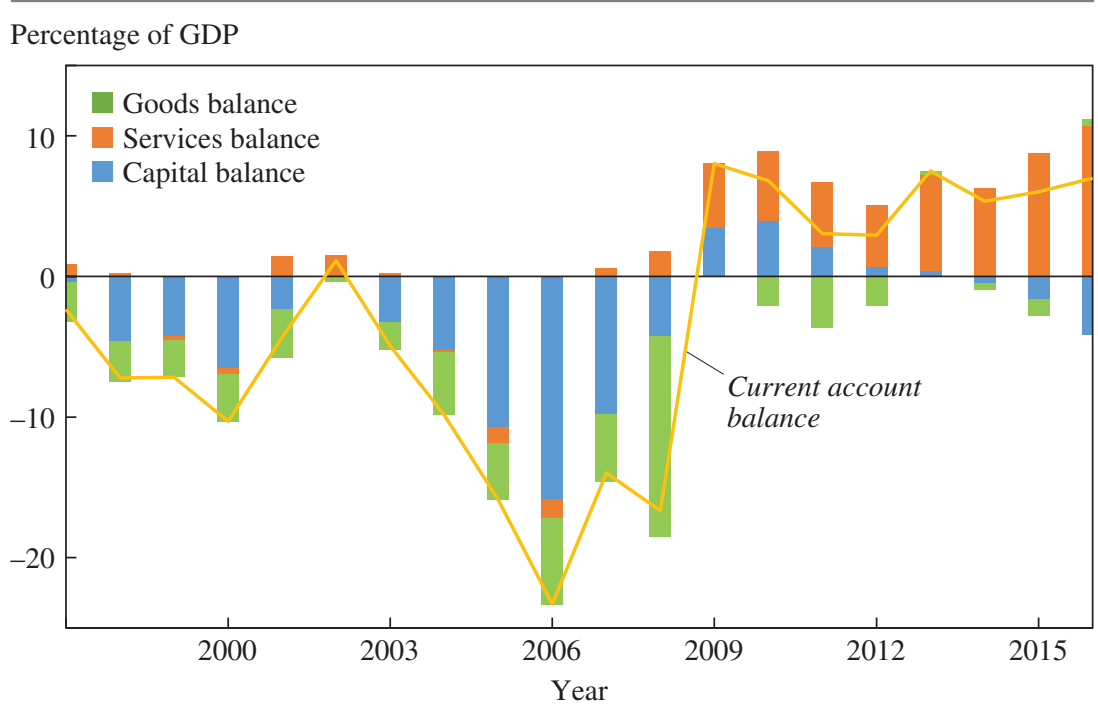

Source: Central Bank of Iceland.

Figure 8. New Car Registrations in Iceland, 2000-17

Thousands

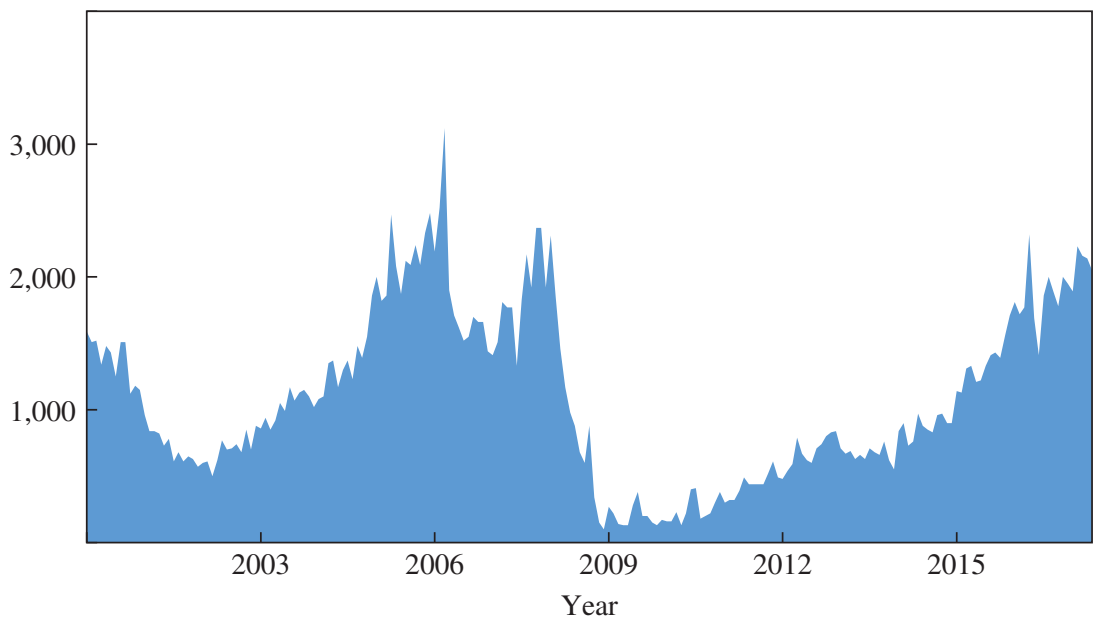

Source: Central Bank of Iceland. 
Figure 9. GDP and Consumer Expenditures Growth, 2000-16

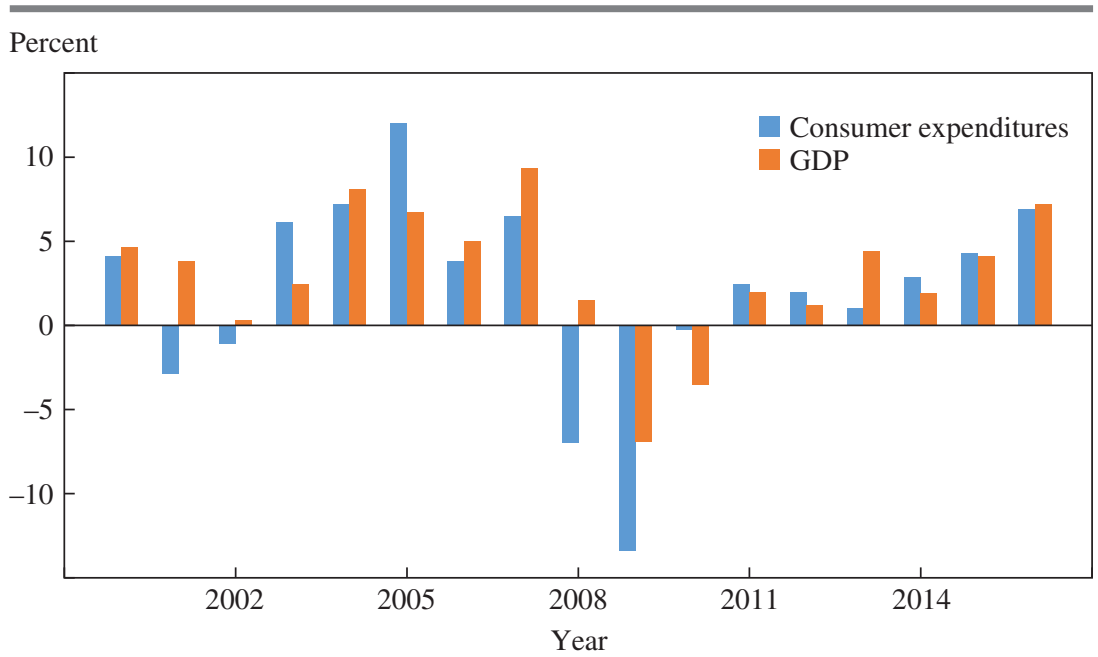

Source: Statistics Iceland.

sounds like a lot. But consumption and consumer expenditures are not the same thing. It was consumer expenditures that fell by 20 percent in Iceland, not consumption. Much of what happened was that Icelanders did not purchase new cars and washing machines for a few years, and the old ones got a bit older. However, this lull in durable goods purchasing came right after an enormous boom in the purchases of such goods, so Iceland had a pretty good stock of durable goods going into the crisis.

In the short run, exports did not react much to the exchange rate change. This is because Iceland's traditional exports are capacity constrained. Iceland exports mainly fish and aluminum. There is a maximum allowable catch in Iceland to prevent overfishing, and fishing is hugely profitable. Icelanders therefore exhaust their maximum allowable catch every year, no matter what the exchange rate is. In the case of aluminum, Iceland is really exporting electricity. Bauxite is imported, and is smelted into aluminum in Iceland, with electricity being the main domestic input. The aluminum smelters in Iceland run at capacity no matter what the exchange rate is. In the longer run, there has, however, been a substantial response on the export side with the rise of the tourism industry. In 2016, the balance on the service account in Iceland was positive by 10 percent of GDP.

Since the crisis, there has been an intense debate about the value of exchange rate flexibility. In particular, prominent commentators have 
argued that the eurozone should be disbanded. Does Iceland's experience during the crisis prove the case for flexible exchange rates? I am not sure. Being able to devalue during the crisis was obviously valuable for Iceland. However, arguably, Iceland has paid for that privilege in good times in the form of very high interest rates. The fact that Iceland has its own currency, and the fact that it chooses to devalue this currency in bad times, may have reduced the demand for Icelandic assets and thereby increased interest rates in Iceland. Luigi Bocola and Guido Lorenzoni (2017) provide a nice model of this phenomenon.

Therefore, I view the Icelandic króna, and the ability it affords Icelanders to devalue it in bad times, as a form of insurance. This insurance contract pays out handsomely in bad times. But in good times, Icelanders need to pay an insurance premium. Whether it is optimal for Iceland to have this form of insurance depends on the size of the insurance premium and the probability that bad events will occur. It is not obvious to me which way this calculation goes.

\section{REFERENCES FOR THE STEINSSON COMMENT}

Bocola, Luigi, and Guido Lorenzoni. 2017. "Financial Crises and Lending of Last Resort in Open Economies." Working Paper no. 23984. Cambridge, Mass.: National Bureau of Economic Research.

Calvo, Guillermo A. 1988. "Servicing the Public Debt: The Role of Expectations." American Economic Review 78, no. 4: 647-61.

GENERAL DISCUSSION Robin Greenwood noted that indicators like the ratio of short-term bank liabilities to short-term assets and other similar measures were setting off warning signals in Iceland during the 1990s and early 2000s, and a small industry developed to try to predict currency crises. Shortly after that, Iceland had a small currency crisis, which likely caused foreigners to make a run on the banks. This was not a banking crisis, but rather a problem with the currency. Greenwood wondered why a similar event did not happen during the most recent financial crisis. Events such as the currency crisis of the 1990s are the sorts of things that economists are usually able to see coming.

Nellie Liang was struck by the fact that during the financial crisis, all the banks in Iceland were treated as one bank; they were all written down, all their assets were transferred, and so on. But in a relatively large banking system, not all banks are the same. So the biggest problem in these crisis 
management situations is that if one bank is able to write down the value of its assets, it might force all banks to write them down, which is a big problem. She wondered if there was any way to figure out how important this was to Iceland's recovery. Though she had the sense that Iceland's most recent episode was viewed as a successful crisis management effort, she did not know how applicable its lessons would be to other countries.

Kristin Forbes was struck by the vast interconnections of the Icelandic firms, which are shown most clearly in the authors' figure 21. She wondered if one could do the same sort of exercise for any small country of a similar size, and whether the same pattern of interconnectedness would emerge. After all, it is natural to assume that such interconnectedness will be more prevalent in small countries. Such an exercise would get at the question of whether the results for Iceland are unusual or if they can be extrapolated to other countries. It would be useful to have some sense of benchmarking, and Forbes was not sure whether there was any literature on questions related to working governance and interconnectedness. She was also curious about the authors' positive view of capital controls, which differs from that of most other papers in the literature. She asked the authors to expand on why they believe capital controls worked so well, and if there are lessons to be learned.

Frederic Mishkin viewed labor market flexibility as an important aspect of Iceland's recovery. Talking with Icelanders after the crisis, one of the main themes that emerged was that people tend to be jacks-of-all-trades (for example, a banker might also be a fisherman). This tremendous labor market flexibility in Iceland would be hard to implement elsewhere, but it may have been a positive feature during the country's financial crisis. Mishkin also pointed out the success of regulation-in particular, the political economy of regulation. Icelanders have a strong Nordic culture, and thus pride themselves on being strongly anticorruption; yet at the same time, they had completely ineffectual, politically motivated regulation. A lesson to draw, therefore, is that capital controls can be effective in the context of prudential regulation, and, in particular, in not allowing borrowing in foreign currency. Macroprudential regulation should be the first backstop when dealing with excessive risk-taking in the economy, even more so than monetary policy. But the issue is whether this can be achieved politically. Iceland is a remarkable case because the country has a vibrant democracy, is highly educated, and has a high literacy rate; but the political issues have become very relevant. One cannot just count on regulations without thinking about whether they are politically viable, he concluded. 
Following up on Mishkin's first point about Iceland's labor market flexibility, Steven Davis was struck by the massive restructuring that took place after the crisis, when one-third of the population moved from banking and construction into tourism. He asked if the authors could say something about how important this great change was to the recovery.

Gita Gopinath seconded a point made by discussant Kathryn Dominguez that the consensus view as to why Iceland and Greece are different is because Iceland has a flexible exchange rate and because it deals very differently with its debt problems. Iceland basically defaulted on its debt, whereas Greece still has a huge amount of debt overhang. She noted that the authors did not have a takeaway on this point; more specifically, they did not state whether they believe these two factors are what really distinguishes Iceland from Greece. She got the sense from discussant Jón Steinsson that it was not fiscal austerity that solved the crisis, but Dominguez seemed to imply that it was. Which one was it? she asked. Finally, Gopinath wondered what, if any, the reputation costs have been for Iceland.

Christopher Carroll reiterated what he thought was the biggest question raised by the authors and Dominguez: Why did no one see the Iceland crisis coming or do anything about it? He cast some of the blame on the economics profession, because the central narrative of economics for the past 30 or 40 years has been that central banks only need to manage inflation targets and the financial sector. Former Federal Reserve chairman Alan Greenspan was not the only economist with the view that the financial sector can take care of itself. Of course, many people disagreed with this perspective, but Carroll thought it was fair to say that this was the central narrative of macroeconomics at the time. It was not just the "corrupt Icelandic bankers" who had this view; they were reflecting consensual thinking about macroeconomics. And the political economy had to at least partly reflect what the economics profession was saying.

Gerald Cohen believes that many investors were both enamored with the carry trade, and thought that the currency was completely overvalued. The cost of shorting the currency-for example, a 15 percent negative carry-made it extremely untenable for the vast majority of investors. As a result, the overvaluation went on much longer than one might expect because of the carry. He also noted the importance of aluminum smelters in Iceland. There was a massive boom in investment in the aluminum industry, causing a response from the central bank and higher capital inflows, which then magnified the currency overvaluation and diminished the impact of political tightening. He wondered what would have happened if Iceland had been part of the eurozone and the carry trade had not been a factor. 
Philipp Hartmann began by elaborating on Carroll's remark. Both the Icelandic crisis and the 2008 global financial crisis caught economists off guard, and this justified some soul searching about ways to eliminate flaws and gaps in standard economic frameworks. "We are sitting in the same boat and we shouldn't sink it together, but build it more firmly," he stated.

On the more substantive issues, Hartmann commended the authors for befittingly describing in their presentation how the Icelandic banks could borrow from the European Central Bank (ECB) as part of the carry trade: The Icelandic banks' Luxembourg subsidiaries could become counterparties because they were established in Luxembourg — which is part of the eurozone-under national supervision. At the time of the financial crisis, the ECB was not a banking supervisor, and therefore did not have access to supervisory information. If the competent eurozone supervisor declared a bank to be fit and proper and solvent, then it could become a counterparty for monetary policy operations (subject to some further technical conditions). So the ECB was, in this sense, largely a passive party. In 2014, the ECB was assigned the so-called single supervisory mechanism, which put it in a better position to verify the viability of its counterparties.

Hartmann sensed, however, some skepticism on the side of the authors toward the practice of the ECB to operate with repurchase agreements, as did the Central Bank of Iceland at the time. One major difference between the eurozone and the United States or Iceland is that the eurozone has a single monetary policy but 19 fiscal policies. It was difficult, therefore, for the ECB to start from the U.S. operational model of implementing monetary policy primarily via the direct buying and selling of government bonds. The authors also stressed the question of adequate risk management for central bank repurchase agreements via the active and granular use of haircuts. While the ECB imposes a graduated ladder of haircuts, Hartmann emphasized the importance of steadiness. For example, it would not be good if a central clearing counterparty increased haircuts dramatically when everybody turns out to have a problem. Similarly, if a central bank actively adjusted repurchase agreement haircuts in response to changing risks, this would inject procyclicality into the system.

To conclude, Hartmann asked the authors to expand on the role of foreign lending by the Icelandic banks. Where did the money go, and what happened to that exposure? What role did it play in the breakdown?

Thomas Philippon suggested looking beyond Greece when making cross-country comparisons with Iceland, and also including Cyprus and Ireland. Cyprus and Greece had different levels of corruption-Cyprus was 
much less corrupt, and it has a better court system; Cyprus lets banks go bust, while Ireland bails them out. And on top of this, Iceland has a flexible exchange rate. Interesting possible combinations of factors arise when all four countries are compared.

Robert Hall brought up the question of the largest possible size of an effective financial system in a very small country. He contended that there is theoretically no limit to the size, but he believes there should be a few sensible rules: (i) no interaction with the government-for example, no deposit insurance, and no lending from the government; and (ii) an effective legal system to protect foreigners. Interestingly, many large financial institutions based in the Caribbean operate under exactly this regime. He contended that it is interaction with government that creates the problem, and stated that there is no reason why Iceland cannot have an arbitrarily large financial system as long as it does not have the perverse features inherent in government interaction. N. Gregory Mankiw agreed with Hall's premise. For instance, one might conclude by looking at the size of the financial system in Greenwich, Connecticut-the assets and liabilities of Greenwich firms compared with the GDP of Greenwich-that it is "way, way, way too big." However, for the reasons Hall stated, this is just not a problem.

Warwick McKibbin recalled that in 2006, when he was on the board of the Reserve Bank of Australia, the Central Bank of Iceland invited him to visit Reykjavik because Iceland, in a similar manner to Australia, was having a macroeconomic imbalance whose factors included high housing prices, a housing boom, a strong exchange rate, and a number of largescale aluminum investments. His discussions with the deputy governor were all about the macroeconomics of dealing with emerging imbalances in the economy - not inflation targeting. There was never a mention of the stability of the banking system, which seemed to imply that this was not a relevant consideration. Why did the bank managers not consider the banking problem something to be concerned about? As far as McKibbin could tell, it was not even on their radar.

James Stock was interested in hearing more about what aspects of Iceland's experience might be generalizable to the current U.S. situation, thinking in terms of Dodd-Frank and other related issues. He suspected that the importance of the resolution authority, central bank independence, and a powerful regulatory authority might be generalizable, but that the penalty for defaulting on all foreign deposits might not be, for example.

Gauti Eggertsson believes the biggest takeaway from the authors' exploration of the Iceland crisis is the importance of the interconnectedness of all 
the people and firms. With regard to Philippon's suggestion to compare the experience of Iceland with that of Greece, Cyprus, and Ireland, Eggertsson believes that the primary value added by the present paper is the extravagant level of detail the authors have provided about the particularly Icelandic experience; no one has done anything like this before. The Icelandic banking crisis was followed by two years of investigations, there was a special prosecutor for the bankers, and there was an investigative committee that lifted bank secrecy laws-but all this stopped at the border. And that was the spirit of the paper. It is very difficult to put the experiences of other countries into context, because the level of detail in the Icelandic case is just not available for other countries. For example, the authors tried to make comparisons with the Mexican crisis, which seemed to be of a similar scale, but the level of detail was just not comparable. The objective of the present paper was to very carefully document what happened in Iceland and its dangers, and to put all this in the context of what people warned about at the time, which seemed to have been borne out; many of the problems were pointed out at the time but were ignored. Eggertsson hoped that a banking supervisor reading the paper would ask himself or herself if there were similar shenanigans of which he or she was unaware.

On Gopinath's question on the importance of flexible exchange rates, Eggertsson did not have a firm view, other than that they seemed to have played some role. In particular, the tourist sector was very price elastic, so it was important in that aspect. In terms of reputational costs, he noted that the government never actually defaulted on its debt; the problem was with private enterprise. The government split the banks up and bailed out their domestic portions, and there is no reason the government should not be able to do that, he said. Taxpayers may feel that is in the best interest of the country.

With regard to comments raised about protecting foreign creditors, Eggertsson believes that any large democracy with a large exposure to international depositors will find it impossible to be seen as soft on creditors. People should be more careful where they put their money, depending on the country out of which the bank operates, given varying degrees of implicit or explicit guarantees.

Sigríður Benediktsdóttir added that new measures have been put in place that basically prevent banks from making term conversions in foreign currency; terms, liabilities, and assets in foreign currency must be purely matched. She explained that Iceland has put in place liquidity and funding rules that draw a very strict box around how banks can fund themselves and have assets and liabilities in foreign currency. 
On Hall's and Mankiw's point about arbitrarily large financial sectors, Benediktsdóttir said that in theory that might be correct, but in practice one would likely end up with a banking system like the U.S. system of the 1800s and 1900s, when bank runs occurred every five to seven years because there was no lender of last resort. The upper limit on the size of the financial system, therefore, is the size of the central bank, because it is the lender of last resort; if a bank were to be any larger, a bank run on a country would be guaranteed, she concluded.

Hall responded briefly by stating that no one claims financial institutions must make face value promises to their creditors. He explained that in the United States, the problem has been solved with money market funds, which are not allowed to make face value promises: "That's all you need to avoid a run. You don't need anything more complicated than that." 